\title{
Namibia: Selected Issues and Statistical Appendix
}

This Selected Issues paper and Statistical Appendix for Namibia was prepared by a staff team of the International Monetary Fund as background documentation for the periodic consultation with the member country. It is based on the information available at the time it was completed on January 8,2008. The views expressed in this document are those of the staff team and do not necessarily reflect the views of the government of Namibia or the Executive Board of the IMF.

The policy of publication of staff reports and other documents by the IMF allows for the deletion of market-sensitive information.

To assist the IMF in evaluating the publication policy, reader comments are invited and may be sent by e-mail to publicationpolicy@imf.org.

Copies of this report are available to the public from

International Monetary Fund • Publication Services

$70019^{\text {th }}$ Street, N.W. • Washington, D.C. 20431

Telephone: (202) 623-7430 • Telefax: (202) 623-7201

E-mail: publications@imf.org • Internet: http://www.imf.org

Price: $\$ 18.00$ a copy

\section{International Monetary Fund}

Washington, D.C. 



\section{INTERNATIONAL MONETARY FUND}

NAMIBIA

\section{Selected Issues and Statistical Appendix}

Prepared by Peter Allum, Lawrence Dwight and Chuling Chen

Approved by the African Department

January 8, 2008

Contents

Page

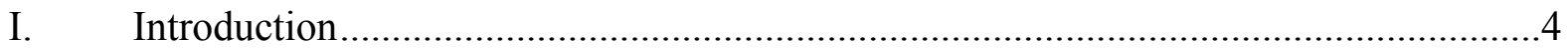

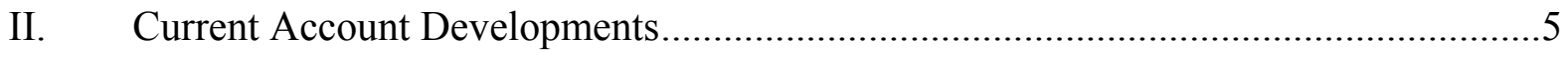

A. Trends in Namibia's External Current Account ….......................................5

B. Savings-Investment Trends...............................................................

C. Implications for Net Foreign Assets .................................................... 12

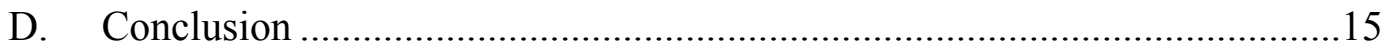

III. Namibia’s Domestic Investment Requirements: Policy Issues ...............................17

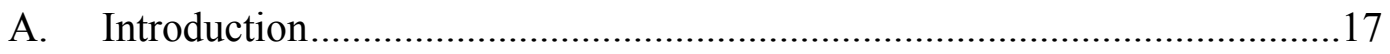

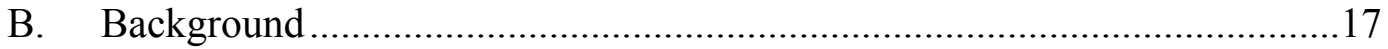

C. The Case for Domestic Investment Requirements....................................22

D. Policies to Encourage Financial Flows to Namibia ..................................27

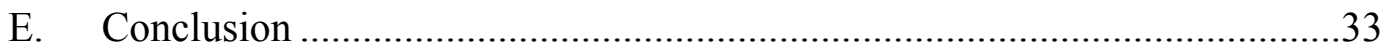

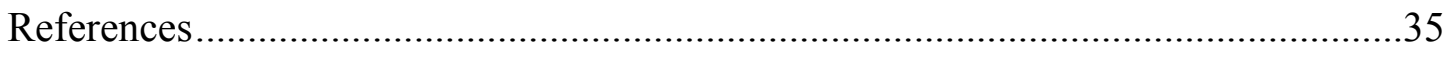

IV. Management of Non-Renewable Natural Resources ...........................................36

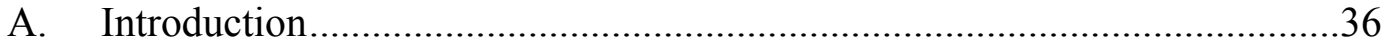

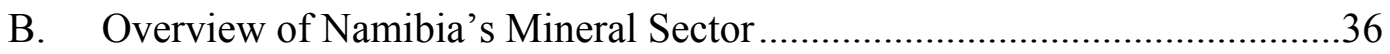

C. Namibia's Institutional Framework for Resource Exploitation....................38

D. Fiscal Management of Natural Resource Earnings ..................................42

E. The Macroeconomic Impact of Resources Extraction...............................48

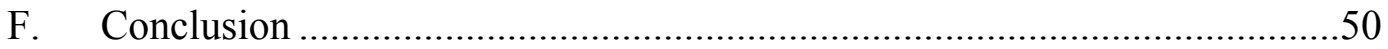

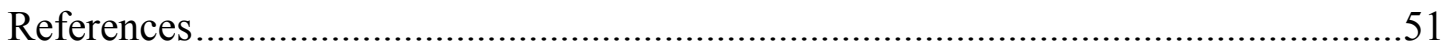

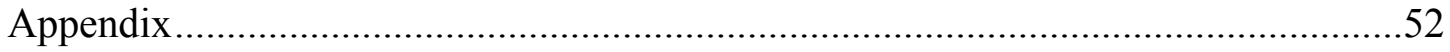




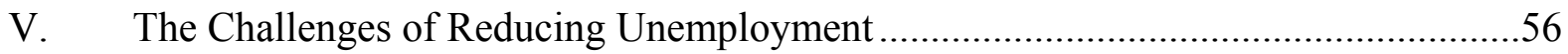

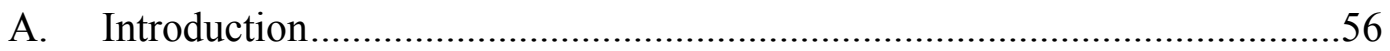

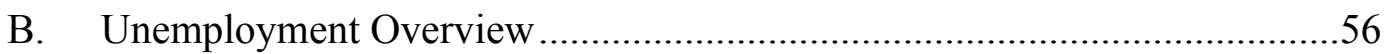

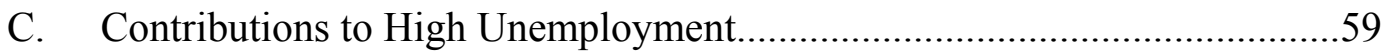

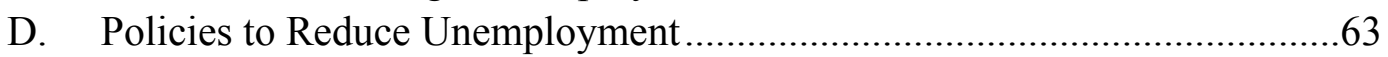

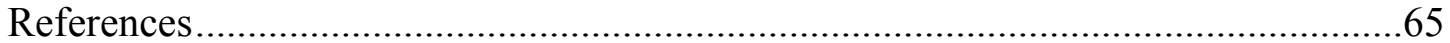

Text Boxes

III.1. Experiences with the Introduction of Mortgaged Backed Securities Markets .........29

IV.1. The Legal and Regulatory Regime for Minerals ....................................................40

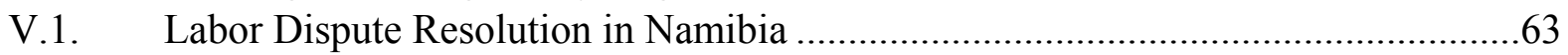

Figures

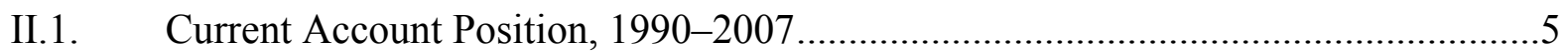

II.2. Current Account Positions of Lower Middle-Income Countries, 2006 .......................6

II.3. Public Savings, Investment, and Current Account Impact .........................................

II.4. Private Savings, Investment, and Current Account Contribution................................ 8

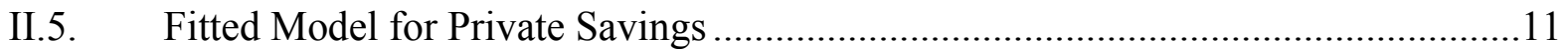

II.6. External Current Account Projections, 2007-12 …...............................................12

II.7. Net Foreign Asset Projections, 2007-12 ……....................................................

III.1. Net Financial Flows and Balance of Payments, 2001-06......................................18

III.2. Increasing Net Foreign Assets of the Banking System, 2005-07 ............................24

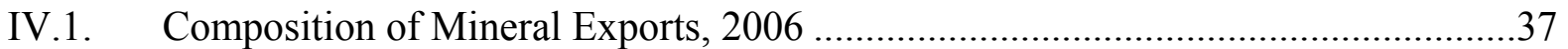

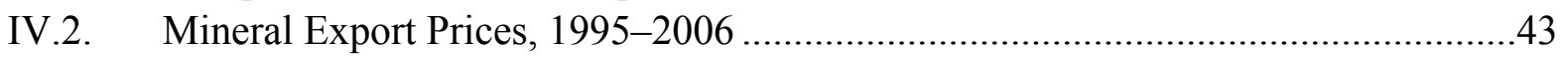

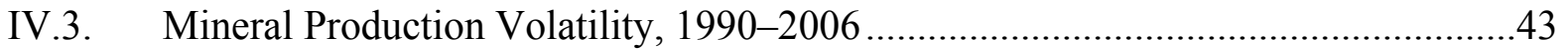

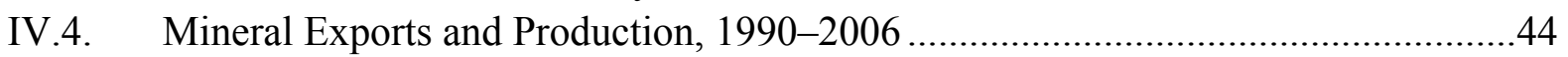

IV.5. Mineral Tax Revenues and the Exchange Rate, 1990-2006 .................................45

IV.6. Revenues and Fiscal Impact, 1989/90-2005/06 ..................................................46

IV.7. Mineral and Other Revenue Contributions, 1991/92-2005/06 ...............................47

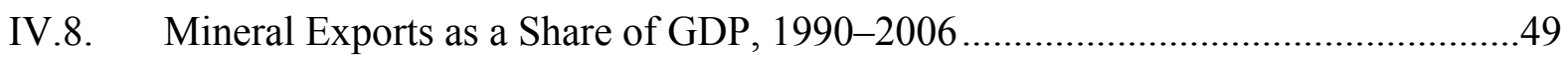

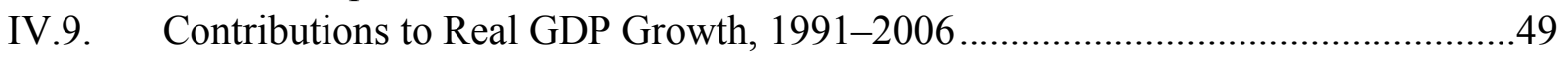

V.1. GDP Growth, Employment, and the Labor Force ................................................58

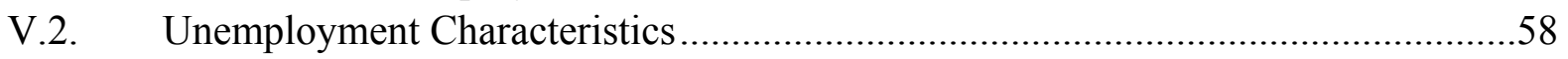

V.3. Discouraged Workers and Under Employment ....................................................58

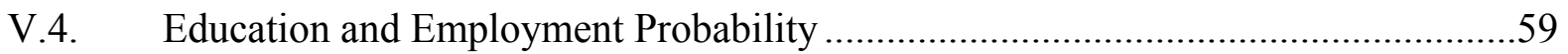

V.5. Annual Employment Growth by Industry, 1997-2004 ...........................................60

V.6. Median Monthly Wage for Production Workers ......................................................61

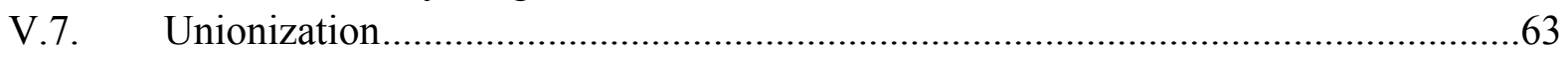


Text Tables

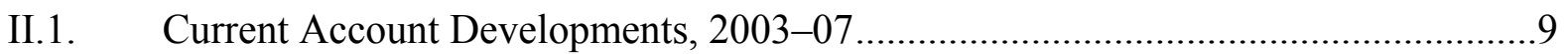

II.2. Fiscal Savings Relative to the 1990-2005 Average ...............................................

II.3. International Investment Position, 1998-2006 ……............................................

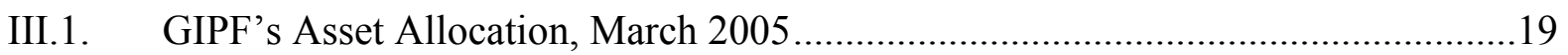

III.2. Asset Allocation of Namibian Fund Managers, March 2002 ..................................19

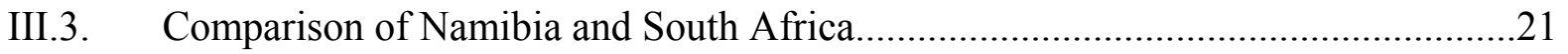

III.4. Pension Fund Investment in Domestic Assets, 2001-02 ......................................23

III.5. Impact of Tightening Domestic Investment Requirements ...................................26

IV.1. Resource Sector Volatility in African Countries, 1997-2006 …………..................4

IV.2. Short-Term Fiscal Pass-Through, 1990-2005 ......................................................46

V.1. Labor Force Participation and Unemployment.....................................................5

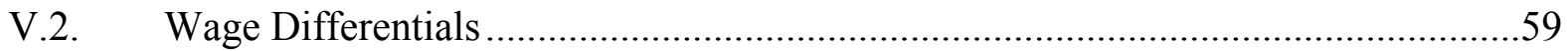

V.3. Manufacturing Share in GDP and Merchandise Exports..........................................61

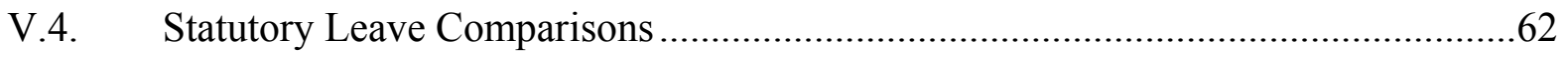

Tables

1. GDP and Gross National Income (GNI) at Current Prices, 2001-06 .......................66

2. GDP by Industrial Origin at Current Prices, 2001-06 ..........................................66

3. Sector Shares of GDP at Current Prices, 2001-06 ..............................................66

4. GDP by Industrial Origin at Constant 1995 Prices, 2001-06 .................................69

5. GDP Growth by Industrial Origin at Constant 1995 Prices, 2001-06 ......................70

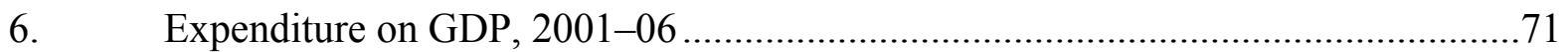

7. National Consumer Price Index (NCPI), January 2005-October 2007 ……….........72

8. Financial Operations of the Central Government, 2001/02-2006/07 .......................73

9. Central Government Revenue and Grants, 2001/02-2006/07 .................................74

10. Central Government Revenue and Grants (Percent of GDP), 2001/02-2006/07 .....75

11. Central Government Expenditure, 2001/02-2006/07 ............................................76

12. Central Government Expenditure (Percent of GDP), 2001/02-2006/07 ...................77

13. Outstanding Debt of the Central Government, 2001/02-2006/07 ...........................78

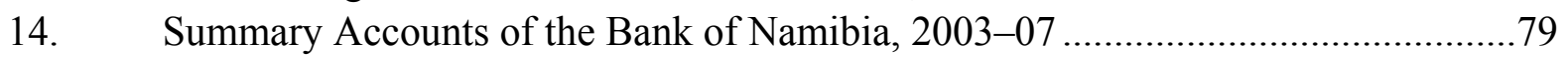

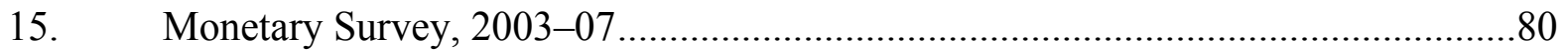

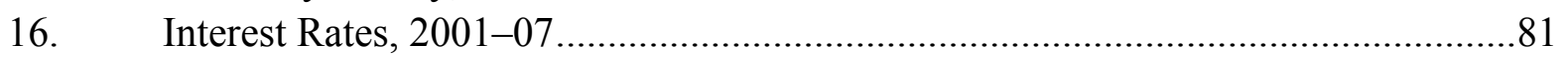

17. Selected Indicators of Stock Exchange Activity, 2001-07 .....................................8

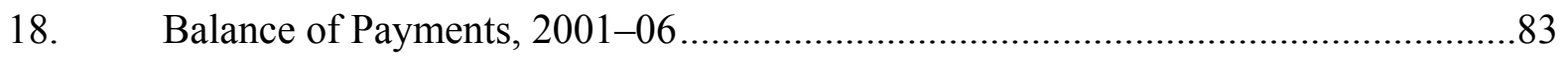

19. Merchandise Exports by Commodity Group, 2001-First Half of 2007 ....................84

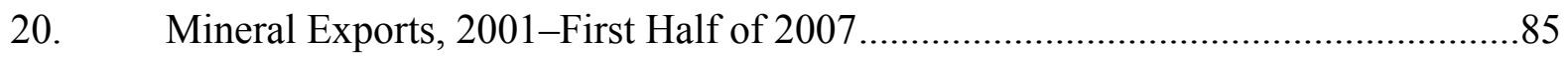

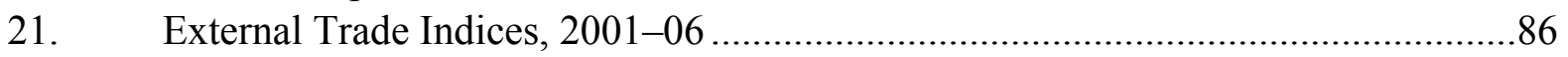

22. Merchandise Imports by Commodity Group, 2001-06 ........................................... 87

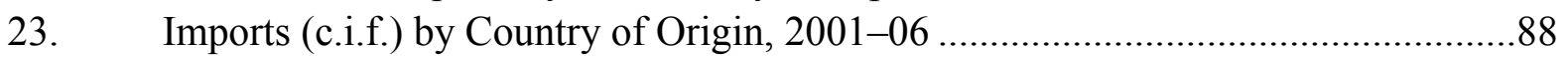

24. Exports by Country of Destination, 2001-06 ………...........................................89

25. Developments in the Exchange Rate of the Namibia Dollar, 1998-2007 ................90 


\section{INTRODUCTION}

1. Namibia's economic position has been reinforced over the past year by a substantial terms of trade improvement and large receipts from the Southern African Customs Union (SACU). This has contributed to significant external current account and fiscal surpluses. The macroeconomic challenge is to promote stronger and more broad-based growth, while preserving macroeconomic stability in the context of possible declines in the terms of trade and SACU receipts in the period ahead. To complement the staff report for the 2007 Article IV consultation, these selected issues papers provide additional analytical coverage in the following areas.

\section{Namibia's current account surpluses have risen to a high level and raise} questions about currency valuation. Chapter II explores the factors behind recent external performance, and finds that a large part of the recent current account surpluses is temporary, reflecting a tight fiscal stance that is projected to ease in the period ahead. A parallel rise in private sector savings and an associated accumulation of net foreign assets is less well understood, and represents a topic for further analysis.

3. The government is considering regulatory steps to slow capital outflows through the pension and life insurance industry, and encourage more domestic investment. Chapter III explores international experience with such regulations, and highlights a number of risks. A case is made for expanding the range of investable assets, to encourage a market-based move toward greater domestic investments.

4. Namibia's important mineral sector is benefiting from a substantial rise in global commodity prices. Chapter IV explores how Namibia has successfully managed its natural resource sector in the past, avoiding the "resource curse" that has struck a number of its peers. It concludes that current institutions are well-placed to manage new mineral investments and exports, though a number of public financial management reforms would be beneficial.

5. Outside the mineral sector, weak job growth and stubbornly high unemployment are among Namibia's main economic challenges. Chapter V explores the nature of the unemployment problem, and notes the importance of strengthened education and training, and more flexible labor markets. 


\section{NAMibia: Current ACCount Developments ${ }^{1}$}

6. Namibia has experienced uninterrupted current account surpluses since independence in 1990, a record unusual among middle-income countries. Moreover, the estimated surplus surged to more than 15 percent of GDP in 2006, unusual even for Namibia. This chapter briefly explores the factors behind this increase, and considers the likely evolution of the current account over the medium term.

\section{A. Trends in Namibia's External Current Account}

7. Namibia's current account surplus has increased in two phases. After averaging 3 percent of GDP during 1990-2002, the surplus rose to an average of 7 percent in 2003-05, and then to an estimated average of 17 percent of GDP in 2006-07 (Figure II.1). ${ }^{2}$

Figure II.1. Namibia: Current Account Position, 1990-2007

(In percent of GDP)

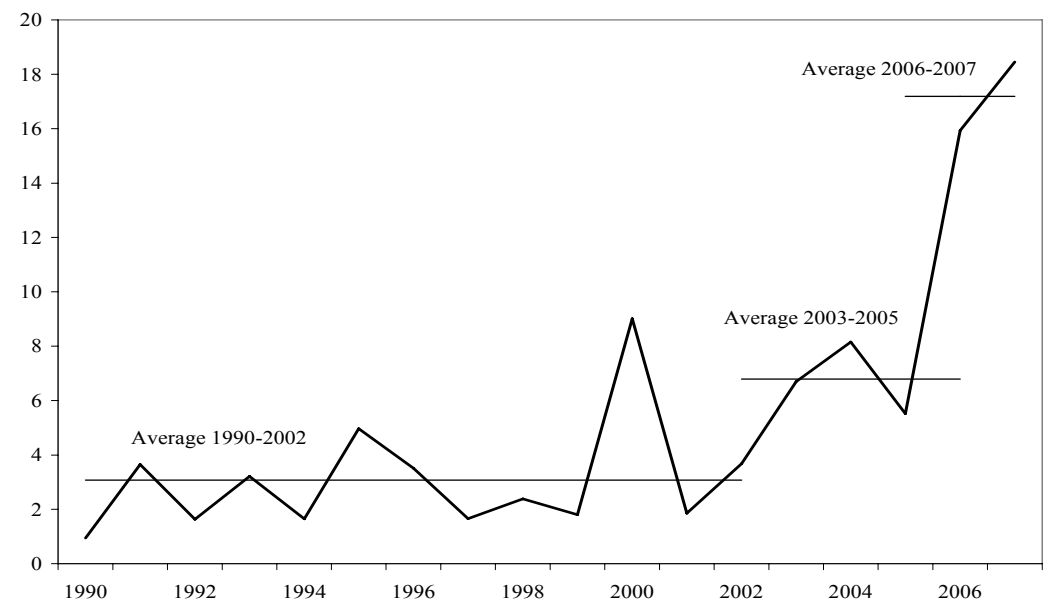

8. The most recent surpluses are high not only by Namibia's past standards, but also by the standards of lower middle-income countries (LMICs). In 2006, Namibia was in the top 10 percent of LMICs, ranked by current account performance (Figure II.2).

Significantly, almost all of the strong performers were exporters of petroleum products or, like Namibia, mineral exporters, benefiting from high global commodity prices.

\footnotetext{
${ }^{1}$ Prepared by Peter Allum (AFR).

${ }^{2}$ The 2007 estimate is projected using first-half data.
} 
Figure II.2. Namibia: Current Account Positions of Lower Middle-Income Countries, 2006 (In percent of GDP)

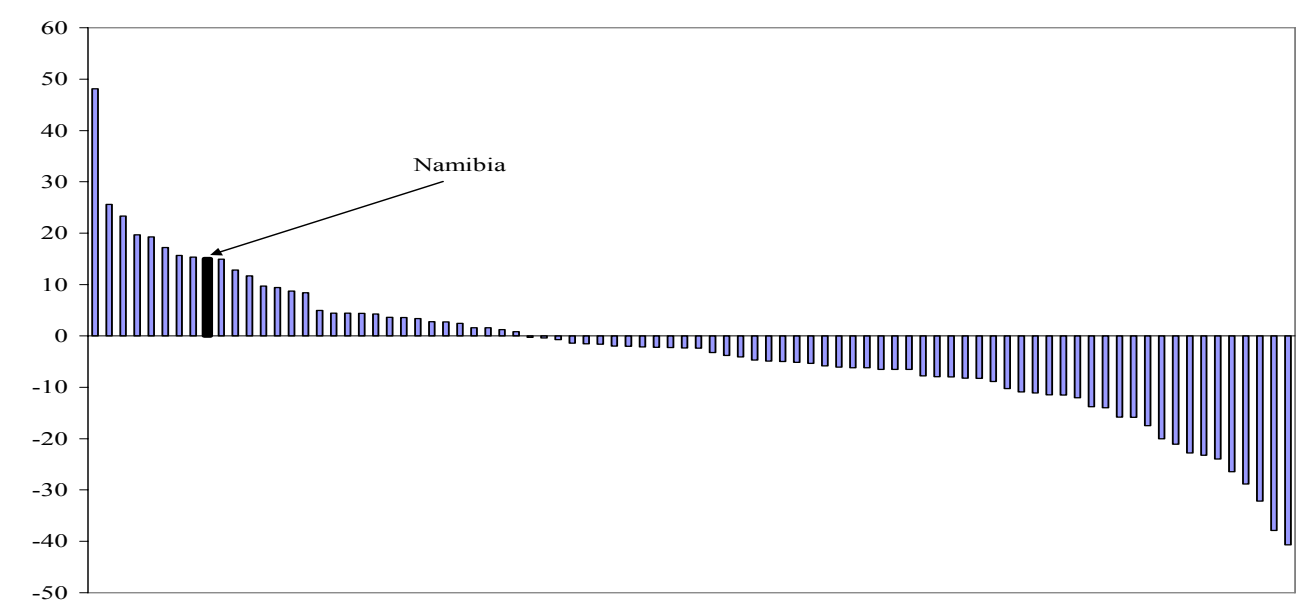

9. To assess external stability, a measure of the underlying current account position is needed. This differs from the observed current account in excluding temporary factors, including short-lived shifts in the fiscal stance, temporary terms of trade shocks, and the lagged impact of exchange rate movements. The underlying current account position is conventionally derived from the medium-term macroeconomic framework. External stability is then assessed by comparing the underlying, or projected current account with the "equilibrium", derived from the perspective of consumption-smoothing in the relevant economy.

\section{An assessment of external stability is thus a multi-step process, requiring consideration of the following factors:}

- How well do we understand the observed current account position?

- How is the current account likely to evolve over the medium term? (What temporary factors are likely to unwind? And what new influences will emerge?)

- What is the equilibrium current account? (Given residents' goals for net external assets, and the need to avoid risks of abrupt shifts in capital and financial flows.)

11. Three approaches are commonly adopted to explore external stability: (a) the macroeconomic balance (MB) approach, which seeks to directly model the determinants of savings and investment; (b) the external stability (ES) approach, which explores the impact of savings-investment decisions on net foreign asset holdings; and (c) the equilibrium real 
exchange rate (ERER) approach, which seeks to directly model real exchange rate developments in terms of the reduced form determinants of savings and investment. ${ }^{3}$

\section{This paper focuses on the macro balance and external stability approaches.}

Sections A-B below extends the macroeconomic balance approach through a detailed assessment of the determinants of savings and investment developments in Namibia. Section $\mathrm{C}$ explores the implications for net foreign assets, using the external stability approach. The equilibrium real exchange rate approach was investigated in some detail by Miyajima (2007) and is not extended here. ${ }^{4}$ An update of Miyajima's estimated ERER model is discussed in the staff report for the 2007 Article IV consultation.

\section{B. Savings-Investment Trends}

13. For analytical purposes, the external current account position can be considered in terms of its relationship, by identity, with national savings and investment, decomposed into behavioral elements for the public and private sectors:

$$
\begin{aligned}
\mathrm{CAB} & =\mathrm{SAV}-\mathrm{INV} \\
& =\left(\mathrm{SAV}_{\mathrm{pub}}-\mathrm{INV}_{\text {pub }}\right)+\left(\mathrm{SAV}_{\text {priv }}-\mathrm{INV}_{\text {priv }}\right)
\end{aligned}
$$

where, $\mathrm{CAB}$ is the current account balance; $\mathrm{SAV}$ is national savings; INV is gross domestic investment; and the pub and priv subscripts refer to the public and private sectors. The observed trends and projections for these elements are discussed below.

\section{Public sector developments}

\section{Public saving rose sharply in 2006 and a further strong outturn is projected}

for 2007. After averaging 1.5 percent of GDP during 1990-2005, public saving rose to nearly 8 percent of GDP in fiscal year 2006/07, and a further increase to 9 percent is projected for $2007 / 08$. With broadly stable public investment relative to GDP, this tightening of the fiscal stance makes a substantial contribution to the strong external current account in 2006-07 (Figure II.3).

\footnotetext{
${ }^{3}$ See IMF, "Methodology for CGER Exchange Rate Assessments", November 2006, available at http://www.imf.org/external/np/pp/eng/2006/110806.pdf.

4 “What Do We Know about Namibia's Competitiveness", Ken Miyajima, IMF Working Paper, WP/07/[ ], August 2007.
} 
Figure II.3. Namibia: Public Savings, Investment, and Current Account Impact (In percent of GDP)

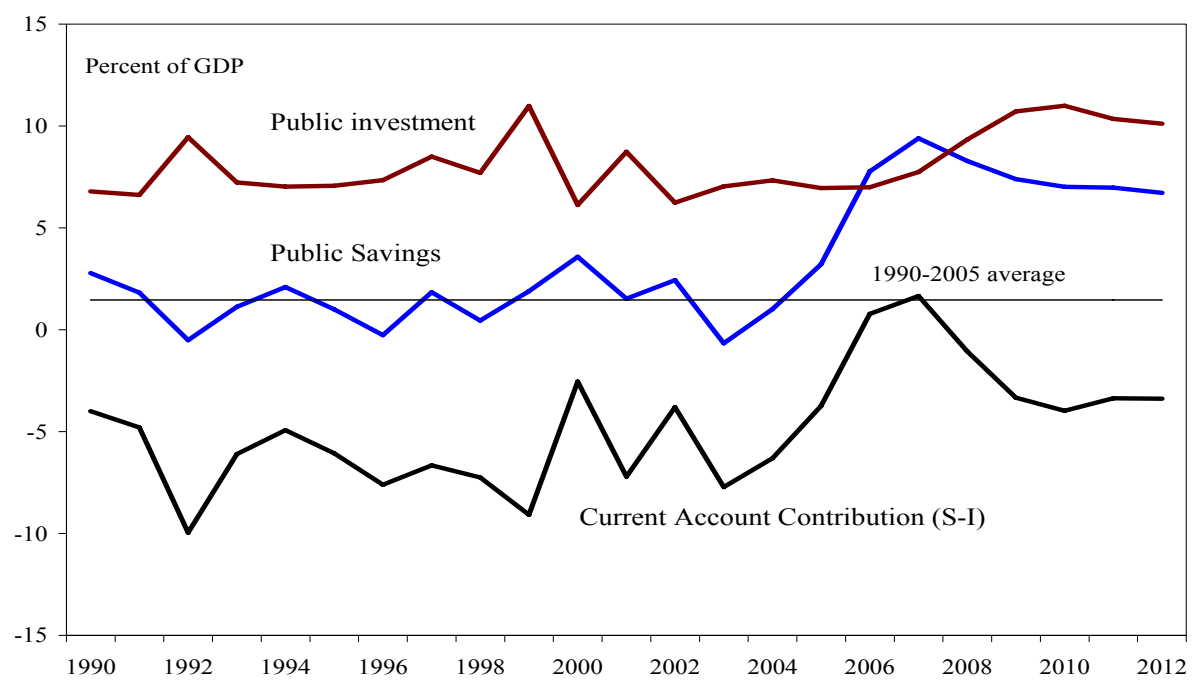

\section{Private sector developments}

15. Private savings also increased around 2003. Compared to the preceding 1990-2002 period, savings in 2003-05 were up 8 percentage points of GDP, only partly offset by a rise in investment spending. This contributed to a stronger external current account position, a trend that continued in 2006-07 (Figure II.4).

Figure II.4. Namibia: Private Savings, Investment, and Current Account Contribution (In percent of GDP)

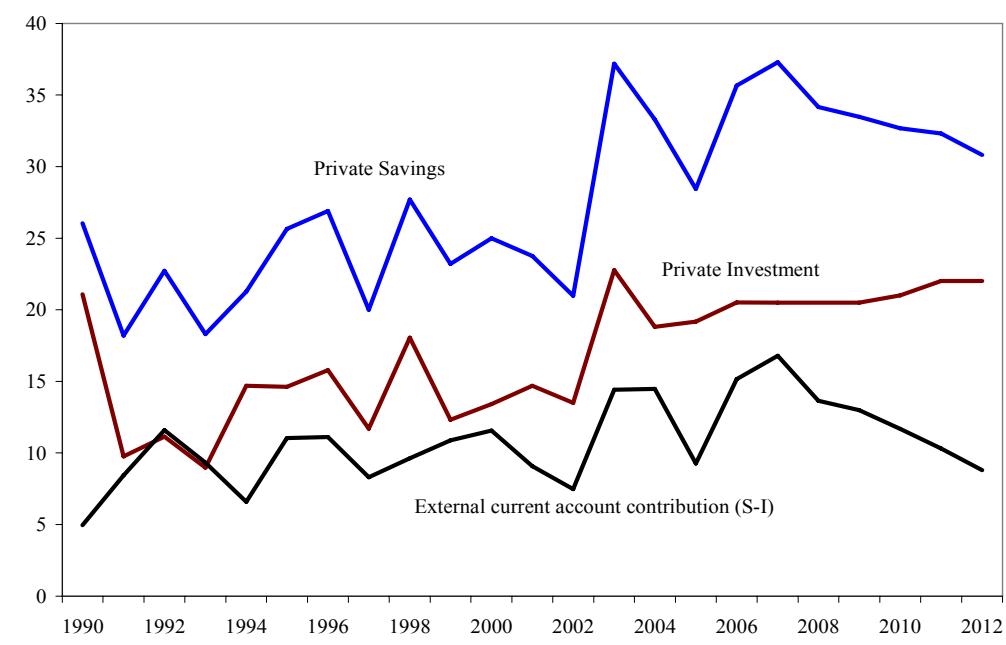

16. Namibia's increased current account surplus thus reflects increased savings by both the public and private sectors. The initial strengthening of the current account position from 2003 was largely driven by private sector savings, while the further increase in $2006-07$ is explained roughly $50-50$ by developments in public and private finances (Table II.1). 
Table II.1. Namibia's Current Account Developments, 2003-07 (changes from 1990-2002, in percent of GDP)

\begin{tabular}{cccccccc}
\hline & $\begin{array}{c}\text { Public } \\
\text { savings }\end{array}$ & $\begin{array}{c}\text { Public } \\
\text { invest- } \\
\text { ment }\end{array}$ & $\begin{array}{c}\text { Public } \\
\text { finances } \\
1 /\end{array}$ & $\begin{array}{c}\text { Private } \\
\text { savings }\end{array}$ & $\begin{array}{c}\text { Private } \\
\text { invest- } \\
\text { ment }\end{array}$ & $\begin{array}{c}\text { Private } \\
\text { finances } \\
1 /\end{array}$ & $\begin{array}{c}\text { External } \\
\text { current } \\
\text { account }\end{array}$ \\
\hline 2003 to 2005 & -0.3 & -0.6 & 0.2 & 9.9 & 6.4 & 3.5 & 3.7 \\
2006 to 2007 & 7.1 & -0.3 & 7.4 & 13.4 & 6.7 & 6.7 & 14.1 \\
\hline
\end{tabular}

$1 /$ Net acquisition of financial assets, or savings minus capital investments.

\section{The above framework needs to be fleshed out to understand why savings have}

risen. The national accounts identity between savings, investment, and the current account merely provide a framework for analysis. To assess the current account outlook, the fundamental influences on savings and investment need to be identified and modeled.

\section{Public sector trends}

\section{In the case of the public sector, increased savings from 2006/07 reflect tight} expenditure control and strong SACU receipts. Expenditures were compressed as budget ceilings proved tight relative to strong nominal GDP growth; this contributed about 3 percentage points of GDP to public savings. At the same time, strong SACU receipts contributed about $4-5$ percentage points to savings (Table II.2).

Table II.2. Namibia: Fiscal Savings Relative to the 1990-2005 Average (In percent of GDP)

\begin{tabular}{lrrrrr}
\hline & \multicolumn{4}{c}{ Contribution from: } \\
\cline { 3 - 6 } & $\begin{array}{r}\text { Fiscal } \\
\text { savings }\end{array}$ & $\begin{array}{r}\text { Lower } \\
\text { current } \\
\text { spending }\end{array}$ & $\begin{array}{r}\text { Higher } \\
\text { SACU } \\
\text { receipts }\end{array}$ & $\begin{array}{r}\text { Higher } \\
\text { mining } \\
\text { taxation }\end{array}$ & $\begin{array}{r}\text { Higher } \\
\text { other rev. } \\
\text { \& grants }\end{array}$ \\
\hline $2003 / 04$ to $2005 / 06$ & -0.3 & 0.6 & 0.5 & -0.9 & -0.9 \\
$2006 / 07$ to $2007 / 08$ & 7.1 & 3.2 & 4.8 & 0.0 & -0.5 \\
\hline
\end{tabular}

19. Over the medium-term, the fiscal stance is projected to ease. Savings are projected to decline in parallel with moderating SACU receipts, relative to GDP, while public investment spending is projected to increase. The shortfall of public savings relative to investments over the medium term would be $2-2 \frac{1}{2}$ percent of GDP, smaller than the shortfall over the period 1990-2005 (Figure II.3). This should contribute to a stronger current account position. 


\section{Private sector trends}

20. A number of factors might be expected to influence private savings trends:

- Per capita real GDP growth: international experience suggests a positive relationship between income growth and savings rates;

- Real interest rates: models of consumption behavior commonly find that durables spending is influenced by borrowing costs;

- CPI inflation: where financial markets are not well-developed, and savings are either in cash or low-yielding bank deposits, high inflation erodes savings, encouraging increased consumption;

- Mineral exports in percent of GDP: on the hypothesis that the marginal propensity to save out of volatile mineral incomes is lower, an increase in ineral incomes would boost savings;

- Contractual savings: Namibia's well-developed pension and life insurance schemes would encourage savings, to the extent that they are not offset by reduced voluntary savings; and

- The real effective exchange rate: a more competitive exchange rate boosts incomes and savings through a positive impact on net exports.

21. The role of a number of the above influences was explored in relation to trends in private sector savings during 1990-2006. In regression analysis, a statistically significant relationship could be identified only for inflation and real interest rates. The explanatory power for real interest rates was inferior, however, and this term lost its explanatory power when the inflation term was added. No significant role was identified for the other factors, and the role of contractual savings was not assessed, given the absence of pertinent data. The fitted equation is documented below and in Figure II.5.

$$
\mathrm{SAV}_{\text {priv }}=35.41-1.14 \mathrm{INFL}
$$

(14.3) (4.3) (t-statistics in parentheses)

Adjusted R-squared $=0.52$ 
Figure II.5. Namibia: Fitted Model for Private Savings

(In percent of GDP)

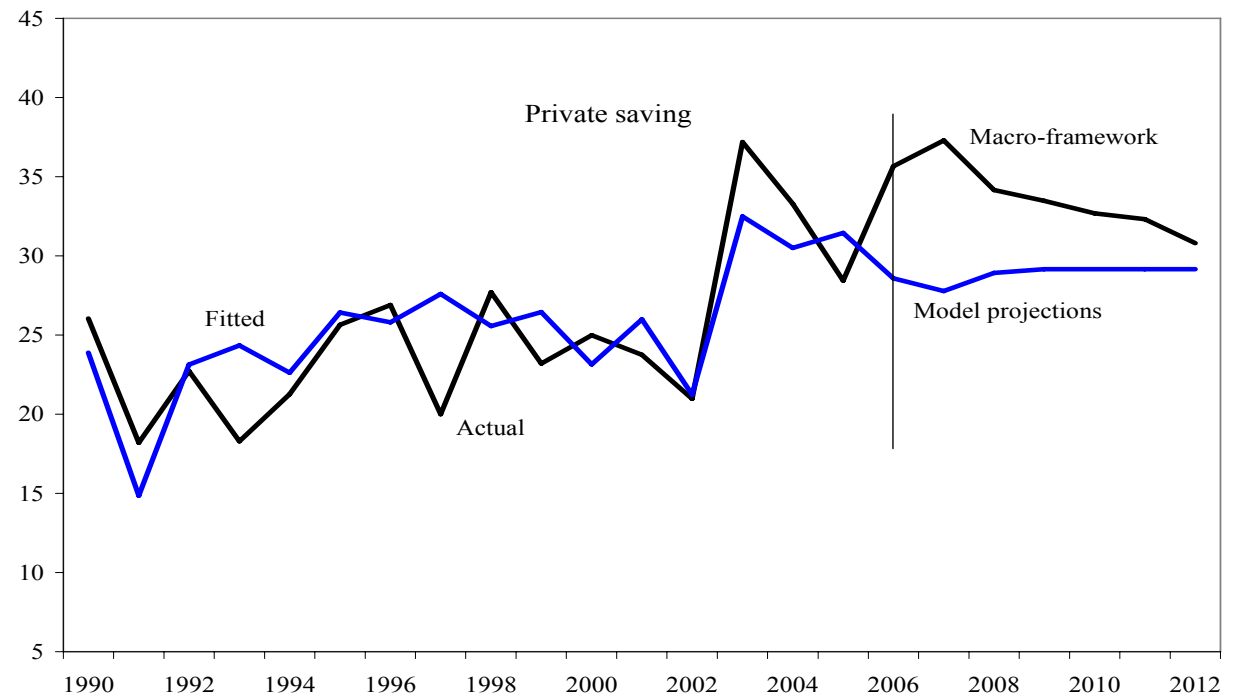

22. The economic basis for this relationship is not entirely clear. The role for inflation in influencing private savings is much larger than international experience would suggest, and may proxy for other influences. This remains an area for further research, along with the potential role of contractual savings. One further possibility is data error. The rise in private saving in 2003 is quite remarkable, and was associated with a sharp fall in real consumption expenditures in that year. Even averaging across the two years to 2003, the data suggest no increase in real consumption expenditures, despite an increase in real GDP of more than 10 percent. This may partly reflect a shift between consumption and investment spending (either real, or as statistical artifact), as private investment surged in 2003. At the same time, however, imports may have been underestimated starting around 2003, which would contribute to both the estimated strengthening of the current account at that time, and the surge in recorded private saving.

23. The estimated equation underpredicts private savings in 2006. On available data, the overperformance of savings is projected to persist through 2007. This increase in private saving may reflect increased mining incomes. Mineral exports rose by 4 percent of GDP in 2006, and although mining operations are largely foreign-owned, these increased incomes may have boosted recorded savings pending payment of taxes and remittance of dividends. Absent corporate income data, this influence on savings is difficult to quantify.

\section{Looking forward, savings are projected to converge toward levels predicted by} the inflation model. This is a tentative projection, given the uncertainties about the role of inflation in influencing private savings, and the unexplained strength of such savings in 2006 and, potentially, 2007. One possibility, indeed, is that the return to savings levels more closely in line with historic norms would be faster than envisaged in Figure II.5. 
25. The economic determinants of private investment are also unclear. Efforts were made to model the investment-GDP ratio in terms of real interest rates, per capita income growth, inflation rates, savings levels, and the real effective exchange rate. None of these proved consistently significant, and the best model of the investment-GDP ratio was obtained using a simple time trend. While this is also an area for further work, and a time trend is not sustainable over the longer term, the medium term framework plausibly assumes a further increase in the investment-GDP ratio, albeit more gradual than over the preceding decade (Figure II.4).

\section{The "underlying" current account}

\section{The medium-term projections for savings and investment developed above} generate an underlying external current account surplus of 5 percent of GDP in 2012

(Figure II.6). Summarizing the above discussion, this reflects:

- An easing of the fiscal stance as a partly temporary rise in public savings is reversed;

- A decline in private savings from exceptionally (and so far unexplained) high levels in 2006, toward an underlying level driven by the inflation model; and

- $\quad$ A further modest rise in private investment, following recent trends.

Figure II.6. Namibia: External Current Account Projections, 2007-12 (In percent of GDP)

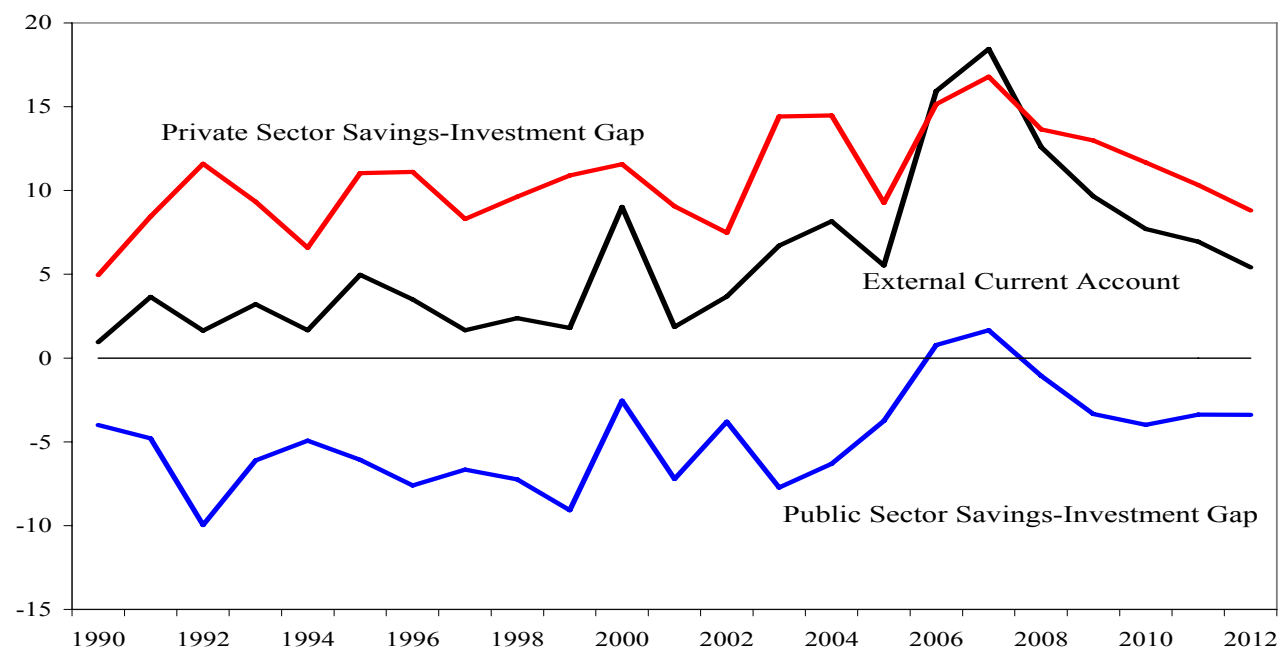

\section{Implications for Net Foreign Assets}

27. Capital outflows have strengthened Namibia's international investment position (IIP). Between 1998 and 2004, Namibia's net foreign asset (NFA) position rose by an estimated 12 percentage points of GDP (with the net liability position declining from 19 percent of GDP to 7 percent). Growing foreign portfolio investments more than 
offset a larger liability position in foreign direct and other investments (Table II.3). A continuing strengthening of the IIP data is evident in 2005 and 2006 data, based on a newly expanded IIP survey. However, the precise trend is clouded by an apparent discontinuity in the foreign direct investment series, which declines from 63 to 39 percent of GDP between 2004 and 2005. Based on the latest survey data, Namibia had an NFA surplus of 22 percent of GDP in 2006.

Table II.3. Namibia: International Investment Position, 1998-2006 (In percent of GDP)

\begin{tabular}{lcrrr}
\hline & \multicolumn{2}{c}{ Historic data } & \multicolumn{2}{c}{ New series } \\
& 1998 & 2004 & 2005 & 2006 \\
\hline Net foreign asset & $\underline{-19.3}$ & $\underline{-7.3}$ & $\underline{9.5}$ & $\underline{22.0}$ \\
Private sector and parastatals & -27.1 & -12.4 & 10.5 & 21.7 \\
$\quad$ Foreign direct investment & -44.4 & -62.7 & -38.7 & -41.2 \\
Portfolio investments & 21.9 & 61.7 & 63.8 & 65.6 \\
Other investments & -4.6 & -11.3 & -14.5 & -2.7 \\
General government & $\ldots$ & $\ldots$ & -5.8 & -6.0 \\
Bank of Namibia & 7.7 & 5.1 & 4.7 & 6.3 \\
\hline
\end{tabular}

\section{This data provides a foundation for analyzing the outlook for foreign asset}

holdings. This is not a straightforward exercise, however. Crucially, there is no clear concordance between the balance of payments data on capital flows and the IIP data on asset stocks. In particular, the increase in Namibia's net foreign asset position between 1998 and 2004 is considerably smaller than would have been expected, given estimated portfolio and other investment outflows and likely rates of return. To the extent that the BOP or IIP data are subject to measurement error, this will influence the reliability of the NFA projections.

\section{For projection purposes, the following assumptions were adopted:}

- Foreign direct investments are assumed to change in value by the difference between underlying inflation - measured by the GDP deflator - and economic depreciation over a 20-year time-horizon (5 percent per annum);

- Portfolio investment holdings are assumed to be split into two-thirds equity investment and one-third fixed-income investment. The former are assumed to rise in line with nominal GDP in South Africa, while the latter earn a nominal interest rate. Capital outflows are assume to include reinvested dividends on equity holdings (with an assumed 2 percent dividend yield) as well as reinvested interest earnings. No exchange rate valuation effects are assumed for the smaller share of investments held outside the common monetary area; and 
- Alternative assumptions were used for the pass-through from capital outflows to net foreign assets. Historically, the difference between capital outflows and NFA accumulation is estimated to have been about 5 percentage points of GDP per annum. If this represents an incorrect attribution of non-resident dividend remittances or capital transfers to the resident capital flow data, the capital outflow data should be discounted for NFA purposes in the period ahead. Alternatively, if the mismatch reflects underestimation of historic NFA data, a pass-through closer to one might be expected.

30. Reflecting the above range of assumptions, Namibia's net foreign asset position is projected to strengthen further, but at a slowing pace. If past trends of a less than full pass-through from capital outflows to net foreign assets continues, the NFA position would stabilize at about 60 percent of GDP, consistent with the above current account projections (Figure II.7). Larger NFA positions would be possible with a more full pass-through from estimated capital flows to NFA.

Figure II.7. Namibia: Net Foreign Asset Projections, 2007-12

(In percent of GDP)

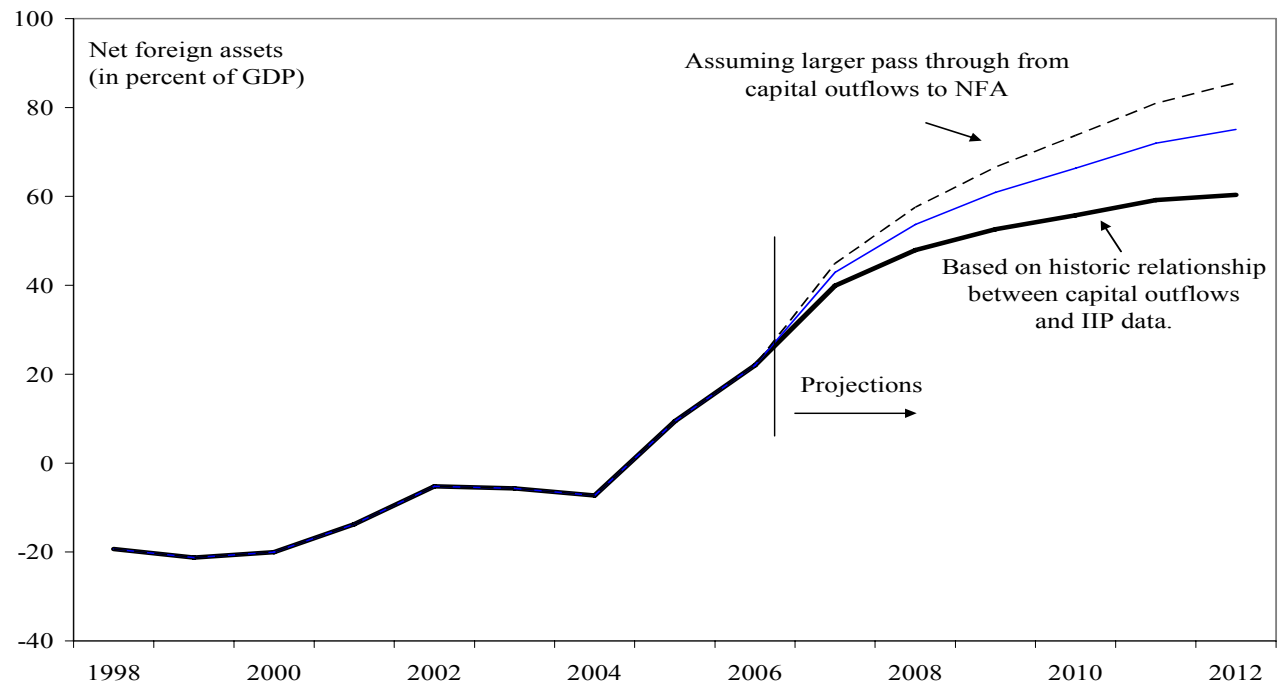

31. On the lower of the above profiles, NFA is projected to rise about 50 percentage points of GDP between 2005 and 2012. Of this total, about 11-12 percentage points reflects a desire by the public sector to strengthen its financial position, comprising a decline in public debt from 30 percent of GDP in 2005/06 to 25 percent over the medium term, and a rise in net international reserves from 5 percent of GDP in 2005 to 11-12 percent of GDP from 2007 through 2012. The basis for the remaining 38 percent of GDP increase in private sector NFA is less evident, though part reflects contractual savings abroad by pension and life insurance schemes, which are large by international standards. 


\section{The increase in private sector NFA does not appear to pose risks of abrupt shifts in capital flows:}

- Portfolio investments abroad were equivalent to 66 percent of GDP at end-2006, largely comprising pension and insurance fund investments. These funds typically invest abroad to the extent that regulations permit, limiting any further outward flexibility. Thus, the main risk would be of portfolio reallocations back to Namibia. Given the limited domestic investment options within Namibia, a major reversal of capital flows by contractual savings funds and other investors toward Namibia appears unlikely unless investment conditions deteriorate very markedly in South Africa. And in these circumstances, it is unlikely that Namibia's investment environment would remain unscathed.

- Direct investments represent a net foreign liability estimated at 41 percent of GDP at end-2006. These investments are largely in the banking and mineral sectors, and an abrupt reversal of capital inflows through divestments appears very unlikely, given the current profitability of both sectors;

- Other investments comprise loans and the net foreign asset positions of the banking sector. As indicated in the above table, these liabilities are modest, estimated at under 3 percent of GDP for the private sector and parastatals, and 6 percent of GDP for the government sector. Given this limited exposure, roll-over risk is not a significant concern. At the margin, capital flows within the CMA may respond to interest differentials between Namibia and South Africa, but the Bank of Namibia is sensitive to this possibility, and has kept official interest rates close to those in South Africa.

\section{Conclusion}

33. The recent uptrend in Namibia's current account surplus reflects, statistically, an increase in public and private savings. The first step-up in the current account surplus dates to about 2003, and reflects an increase in private savings in excess of a parallel increase in private investment. The basis for this increase is not well-understood, and given the unusual nature of the recorded slump in consumer demand at a time when the economy was growing strongly, the possibility of statistical mismeasurement is real. This merits further analysis.

34. A further rise in the current account surplus to double-digit levels in 2006 reflects increases in both public and private savings. The public sector element reflects relatively tight expenditure control at a time of strong nominal income growth, combined with a surge in SACU receipts. The increase in private saving is less well-understood, reflecting limited data on private sector incomes and expenditures. However, this may reflect, in part, a low marginal propensity to consume out of higher mineral export earnings. 


\section{Available data suggest that Namibia's current account surpluses have} contributed to a strengthening NFA position. Again, however, data quality appears to be an issue, with no clear concordance between the modest recorded increases in NFA and the much larger estimated capital outflows. Given this, NFA projections are somewhat perilous, though a further rise appears likely, with a slowing pace as the projected current account surplus declines in the period ahead.

36. The projected further strengthening of Namibia's NFA position, while of uncertain magnitude, does not appear to pose risks of abrupt shifts in capital flows. The main risks would appear to concern possible investment repatriation in excess of the economy's absorption capacity. Given the unlikelihood of a major improvement in Namibian investment returns relative to those in South Africa, this does not appear a significant risk, though it does point up the importance of careful management of the regulations on domestic and overseas investments by the pension and life insurance industries (Chapter III). 


\section{NAMIBIA's DOMESTIC InVESTMENT RequiRements: Policy IsSUeS ${ }^{5}$}

\section{A. Introduction}

37. From 2004 to 2006, Namibia's gross national savings rate averaged 37 percent of GDP, almost double the average for sub-Saharan Africa and 60 percent higher than the lower-middle income country average. ${ }^{6}$ This level of savings supported domestic investments averaging 27 percent of GDP, about 50 percent higher than the sub-Saharan average and slightly above the lower-middle income country average. The excess of savings over domestic investment was invested abroad, largely by Namibia's pension and insurance industry. In light of Namibia's high unemployment and weak employment growth, the government is planning to tighten domestic investment regulations for the pension and insurance industries.

38. This paper examines influences on the investment decisions of pension and insurance funds and the case for tighter domestic investment requirements. It also examines alternative approaches to boosting domestic investments in Namibia. The paper concludes that tightening investment requirements may not be fully enforceable, and may not contribute to financial market deepening. There would likely be an increase in domestic investment, but the regulations would need to be phased-in cautiously to avoid inflationary pressures and a deterioration in asset quality. Given these considerations, a strong case can be made for market-based measures that would attract greater domestic investments by broadening the range of investable assets and by strengthening domestic returns on real sector investments.

\section{B. Background}

39. Namibia has experienced large capital outflows in recent years. From 2003 to 2005, outflows on the financial account exceeded US\$500 million per annum (approaching 10 percent of GDP) and surged to US\$1.3 billion in 2006 (19 percent of GDP). The largest part consisted of net portfolio outflows, which averaged $151 / 2$ percent of GDP. According to international investment position (IIP) data for mid-2007, total gross foreign assets amounted to an estimated 105 percent of GDP, with 70 percent made up of portfolio investment. South African assets made up approximately 80 percent of both total and portfolio investment. Pension and insurance funds are the main intermediaries of portfolio outflows. As of the latest data available (March 2004) the value of their total assets amounted to more than 100 percent of GDP. Using IIP data, staff estimate that total pension and

\footnotetext{
${ }^{5}$ Prepared by Lawrence Dwight (AFR). The author would like to acknowledge the generous comments and contributions of S. Erik Oppers to this chapter.

${ }^{6}$ This reflects, in part, Namibia's large SACU receipts (14 percent of GDP in FY2006/07).
} 
insurance assets had risen to about N\$58 billion (US\$ 8.2 billion) in mid-2007 or about 110 percent of GDP.

Figure III.1. Namibia: Net Financial Flows and Balance of Payments, 2001-06
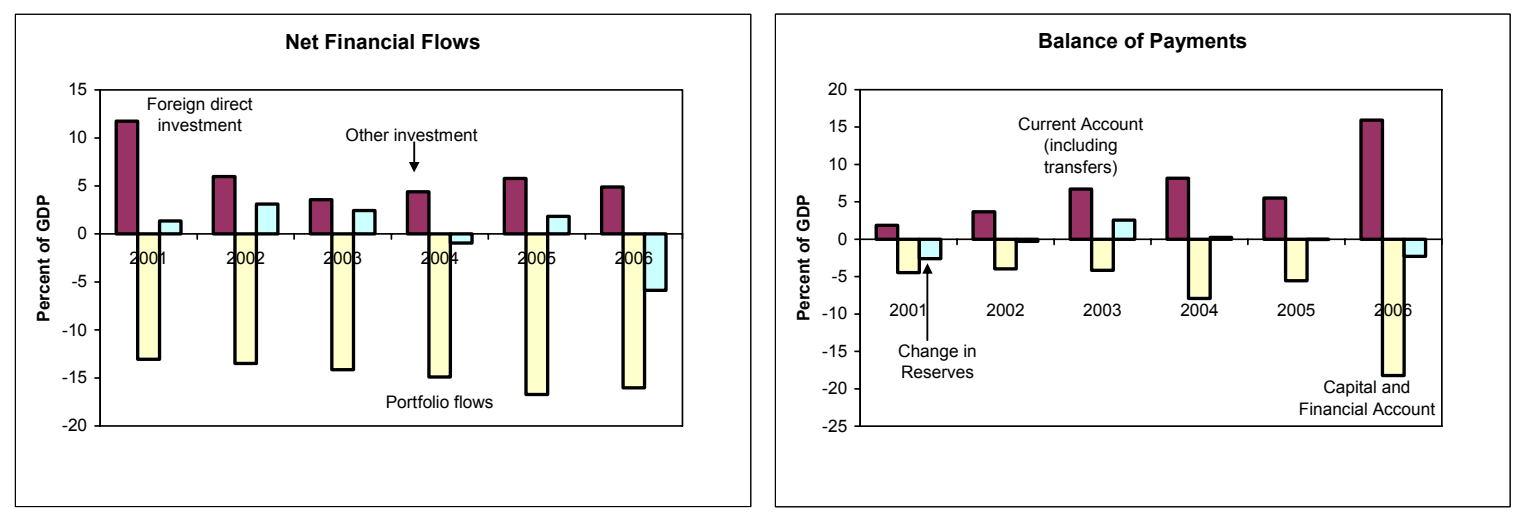

40. Pension fund investments account for about 60 percent of the combined pension/insurance total. Overall pension fund assets under management measured N\$21 billion (57 percent of GDP) as of March 2004 (there are no firm data subsequently). Pension funds have been able to achieve reasonable real returns, averaging a little over 3 percent between 2001 and 2004. While Namibia has more than 500 pension funds, the Government Institutions Pension Fund (GIPF), which covers government employees, held about 73 percent of the industry total. As of March 2005, 67 percent of this portfolio was in equities, 21 percent in fixed income, and the remainder in cash and property (Table III.1).

\section{Insurance company assets totaled N\$14.4 billion (42 percent of GDP) in}

March 2004. Of this amount 92 percent was held by long-term insurers. The life insurance industry in Namibia is privately run, and comprises 16 long-term insurers and 12 short-term insurers. The top three companies hold approximately 85 percent of the market. No data is available on the investment returns of the insurance industry, but with a similar regulatory framework, it is probably comparable to that of the pension fund industry.

\section{Pension and insurance funds invest the majority of their funds in South Africa.}

The GIPF reported that, for end-2006, 46.5 percent of assets were invested in South Africa, 19.0 percent in other foreign countries, and 34.5 percent domestically. While recent data are not available for private fund managers, in early 2002, 48 percent of their portfolio was invested in South Africa, 17 percent in other foreign locations, and 35 percent domestically (Table III.2). Of domestic investments, nearly one-half was in foreign companies dual-listed on the Namibian exchange, reducing true domestic investmentslargely comprising bonds and cash—-to less than 20 percent of total portfolios. 
Table III.1. Namibia: GIPF's Asset Allocation, March 2005

(In percent of total assets at book value)

\begin{tabular}{lcccc}
\hline & Namibia & South Africa & $\begin{array}{c}\text { Other } \\
\text { international }\end{array}$ & Total \\
\hline Total & $\underline{38.3}$ & $\underline{53.8}$ & $\underline{7.9}$ & $\underline{100.0}$ \\
Equities & 20.5 & 39.5 & 6.9 & 66.8 \\
Fixed income & 10.8 & 8.6 & 1.0 & 20.5 \\
Cash & 6.2 & 5.6 & 0.0 & 11.7 \\
Property & 0.8 & 0.2 & 0.0 & 1.0 \\
\hline
\end{tabular}

Sources: GIPF and Fund staff estimates.

Table III.2. Namibia: Asset Allocation of Namibian Fund Managers, March 2002 (In percent of total assets at book value)

\begin{tabular}{lcccc}
\hline & Namibia & South Africa & $\begin{array}{c}\text { Other } \\
\text { international }\end{array}$ & Total \\
\hline Total & $\underline{35.4}$ & 47.5 & 17.1 & 100.0 \\
$\quad$ Primary stocks & 1.6 & & & \\
Dual-listed stocks & 15.7 & & & \\
Bonds & 9.0 & & & \\
Cash & 8.7 & & & \\
Property & 0.4 & & & \\
\hline
\end{tabular}

Sources: NEPRU Research Report No. 26, March 2004.

43. The Namibian stock exchange is primarily composed of dual-listed companies. The seven local firms listed on the exchange comprise only 0.3 percent of market capitalization. Forty-four percent of market capitalization represents firms having primary listings in Johannesburg and 55 percent represents firms having primary listings in London. Nonetheless, dual-listed firms are considered domestic for the purposes of Namibia's domestic investment requirements, a rule established partly to stimulate domestic financial markets.

\section{Regulations on foreign portfolio investments}

\section{Namibia's international capital flows are governed by the Common Monetary} Area (CMA) agreement with Lesotho, South Africa, and Swaziland. Under the agreement, Namibia maintains free transfers of funds for current and capital transactions with other members. At the same time, CMA members are required to align exchange control provisions with South Africa's, including controls on capital flows outside the CMA. The latter include an individual limit of R2 million in investment outside the CMA and the requirement that the government approve outward direct investment of firms. Investment managers are allowed to invest up to 25 percent of total retail assets in non-CMA portfolio investments. Pension funds may only transfer up to 20 percent of their total retail assets to acquire non-CMA portfolio investments. These regulations are applied by the Namibian authorities to the pension and insurance industry in accord with the CMA agreement. 
45. The CMA agreement allows Namibia to introduce domestic investment requirements to promote domestic development and domestic industries. In line with these provisions, in 1994 the government amended Regulation 28 of the Pension Fund Act and Regulation 15 of the Long-Term Insurance Act to gradually increase to 35 percent the share of portfolios that pension and insurance funds must invest in domestic assets. Shares of dual-listed companies on the Namibian Stock Exchange (NSX) are considered domestic if they are purchased on the NSX, and 7 local and 19 dual-listed companies on the NSX qualify. Unit trusts are not required to comply with the domestic asset requirements, but do so in practice to attract investments from pension funds and insurance companies.

\section{With large capital outflows continuing, the Namibian government plans to} introduce measures to tighten domestic investment requirements. Under preliminary proposals, institutional investors would be required to invest a minimum of 5 percent of assets under management in unlisted Namibian firms. In addition, the value of dual-listed companies that qualify for domestic status would be reduced from 100 percent to 10 percent in a phased manner over five years. The details of the phase-in have not yet been announced, but an initial plan indicated that the credit for domestic investments in dual-listed firms would fall to 30 percent in the first year of implementation, and by a further 5 percentage points each subsequent year, reaching 10 percent in the fifth year. The proposals would also subject unit trusts to same domestic investment requirements as pension and insurance funds and their tax-exempt status would be eliminated.

\section{The government has expressed several rationales for tightening domestic} investment requirements. By keeping capital at home, domestic investment requirements would promote local economic and financial market development. As the Bank of Namibia stated in its June 2007 Quarterly Bulletin:

Outflows of resident capital from Namibia have been rising and the argument can be raised that, had this capital been available domestically, it could have encouraged domestic investment and enhanced economic development (p. 48).

48. Internationally, a number of other factors have favored domestic investment requirements. In many cases, prudential concerns about foreign currency exposure are a major consideration. In addition, limits have been presented as contributing to financial market development and as a curb against speculative capital flows.

\section{Namibia as a Destination for Capital Flows}

\section{Before considering the case for intervention, we consider how Namibia might} expect to benefit from its high savings rate. Several factors could favor the domestic investment of these funds. Namibia has seen relatively robust economic growth in recent years and private sector investment has risen from 15 to 21 percent of GDP, suggesting the presence of good investment opportunities. Indeed, Namibia's underdeveloped capital base relative to more advanced economies should indicate the possibility of high rates of return on 
capital. At the same time, international experience suggests that portfolio managers have a strong "home bias" in their investment behavior. As a result, foreign investment managers may be reluctant to invest in Namibia and Namibia could benefit from the substantial portfolios under domestic management. These considerations are explored below.

\section{The Lucas Paradox and Namibia}

50. According to economic theory, capital should flow from richer to poorer countries, reflecting the higher returns on capital in the latter. Moreover, capital should flow to the fastest-growing countries with the best investment opportunities. On this basis, theory would suggest that capital should flow from South Africa to its poorer, but somewhat faster-growing neighbor, Namibia (Table III.3).

Table III.3. Namibia: Comparison of Namibia and South Africa

\begin{tabular}{lcc}
\hline & Namibia & South Africa \\
\hline PPP per capita GDP (2005) & $\$ 2,990$ & $\$ 4,770$ \\
Real growth rate (2001-06) & 4.7 & 4.1 \\
\hline
\end{tabular}

51. Global flows have been the reverse, however. In what has become known as the Lucas Paradox, capital flows to poor countries have been found to be modest, and much lower than predicted (Lucas, 1990). Moreover, there is no clear evidence that capital is attracted to the fastest-growing countries (Prasad, 2007). Recent research has tried to explain the reasons for the Lucas Paradox. One approach has emphasized the importance of fundamental economic causes, including differences across countries in technology, human capital, government policies, and institutional structure. Lucas himself emphasized that differences in human capital mean that returns to capital are not as starkly different as neoclassical growth theory would suggest. Meanwhile, Alfaro (2005) cites differences in institutional structures as critical for explaining capital flows. Another approach has emphasized imperfections in international capital markets, including the risks that sovereign governments will not repay their loans or will expropriate foreign owned assets. Finally, asymmetric information with regard to the risks and returns of investment projects may deter foreign investors.

52. By implication, Namibia may be able to capitalize on its strong growth rates by strengthening the institutions that investors believe are important. Relevant areas for consideration include the protection of investor rights, flexible labor markets, and a good education system. 


\section{Portfolio allocation and home bias}

53. A different approach to modeling capital flows starts with finance theory and portfolio allocation decisions. According to the capital asset pricing model (CAPM), investors should allocate portfolios according to market capitalization. For international portfolios, this implies diversification based on the size of countries' capital markets. Thus, in a truly global portfolio, investments in the United States would have a 39 percent share, those in developed European capital markets a 26 percent share, with investments in Africa at just $1 \frac{1}{2}$ percent, reflecting the small size of African capital markets. In practice, investment funds are rarely truly global, and most have a majority of their investments in domestic assets, even when not required to do so by regulations. This effect has been dubbed "home bias".

54. Namibia's pension and life insurance portfolios show very modest home bias. Funds are close to the 20 percent limit on non-CMA assets and are not much higher than the 35 percent floor on domestic investments. This suggests that the regulations are binding and that foreign investment would be higher and domestic investment lower in their absence. Several factors may contribute to limited home bias. First, Namibia's market capitalization is small, even when compared just to South Africa. Indeed, if investors are restricted to investment in the CMA area, the CAPM would imply that 98 percent of Namibian portfolios should be invested in South Africa. A further factor limiting home bias is the absence of exchange rate exposure for Namibia's investment in CMA assets. Given these considerations, the absence of a strong home bias in Namibia's case is perhaps not a surprise.

\section{The Case for Domestic Investment Requirements}

\section{International experience}

55. A number of countries have imposed domestic investment requirements (or equivalently limits on foreign investment) on their pension and life insurance funds. These include Argentina, Chile, Hungary and Poland, for example, as well as the advanced economies of Germany, Japan, and Canada. Many of these limits are more stringent than those proposed by the Namibian authorities (Table III.4).

\footnotetext{
${ }^{7}$ For a good survey of the theoretical issues related to home bias, see Karen K. Lewis. "Trying to Explain Home Bias in Equities and Consumption," The Journal of Economic Literature, Vol. 37, No. 2 (Jun., 1999), pp. 571608. For a discussion of recent trends in home bias, see the IMF's Global Financial Stability Report, April 2007, pp. 68-71.
} 
Table III.4. Namibia: Pension Fund Investment in Domestic Assets, 2001-02

(In percent of total assets)

\begin{tabular}{lcr}
\hline & Required Minimum & Actual \\
\hline Mature Markets & & \\
United Kingdom & $\mathrm{P}$ & 77.1 \\
United States & $\mathrm{P}$ & 89.0 \\
Germany & 70 & 93.0 \\
Japan & 70 & 77.1 \\
Canada & 70 & 85.0 \\
France & -- & 95.0 \\
Italy & $\mathrm{P}$ & 100.0 \\
Weighted Average 1/ & & 87.2 \\
& & \\
Emerging Markets & & 91.1 \\
Argentina & 90 & - \\
Brazil & 100 & 83.6 \\
Chile & 75 & -- \\
Colombia & 90 & -- \\
Hungary & 70 & 35.4 \\
Mexico & 90 & 92.8 \\
Namibia* & 35 & $\underline{99.7}$ \\
Peru & 92 & 94.2 \\
Poland & 95 & \\
Weighted Average 1/ & & \\
& & \\
\hline
\end{tabular}

$\mathrm{P}=$ prudent person rule applies

* = includes dual listed stocks as domestic

1/ Weighted by GDP

Source: IMF Global Financial Stability Report, April 2004, p. 131.

\section{Exchange rate considerations}

56. Tightened domestic investment requirements would not contribute substantially to management of the exchange rate peg. Initially, reduced net outflows could permit the authorities to accumulate a higher pool of international reserves. However, capital mobility would remain largely unrestricted under the CMA agreement, with individuals and banks free to circumvent the tighter regulations governing pension and insurance funds. For example, individuals could invest directly abroad to compensate for the shift toward domestic assets in their total portfolio of wealth (i.e., including pensions). Similarly, if pension and insurance funds start to provide capital for local enterprises, replacing banks as a source of funding, banks may shift their operations out of the local market. Banks could then offer domestic liabilities to the pension and insurance companies for the later to compy with the domestic investment requirements. The banks could then invest abroad themselves. This would effectively circumvent the tighter domestic investment requirements. The current practice of banks to place excess liquidity abroad underscores this possibility. In 2006 for 
example, the increase in the bank's liquid liabilities exceeded increases in net domestic assets. The banks placed the difference abroad.

Figure III.2. Namibia: Increasing Net Foreign Assets of the Banking System, 2005-07

(N\$ Billions)

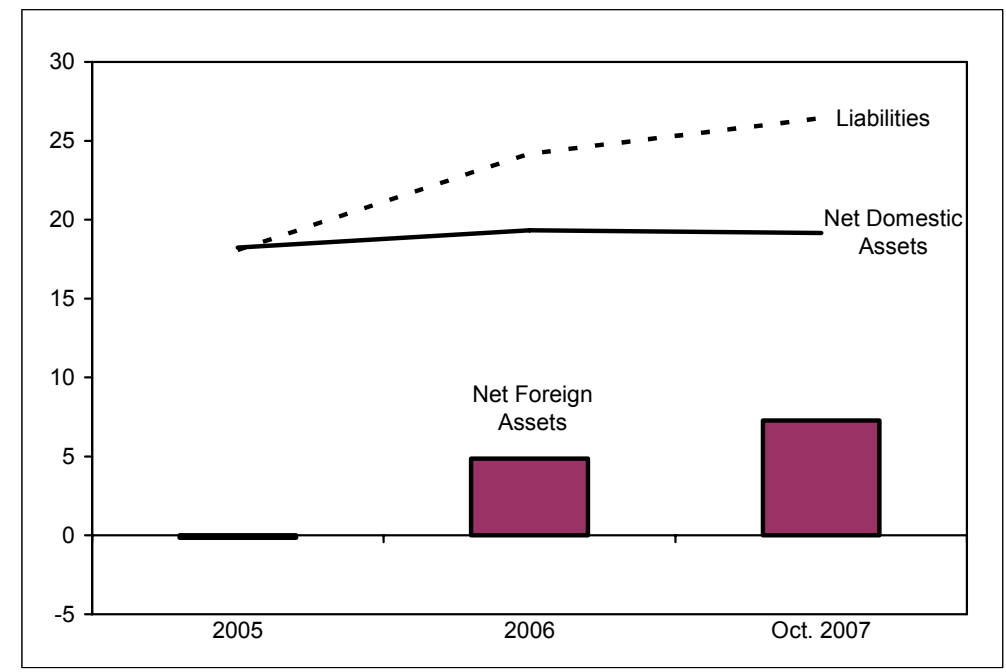

\section{Implications for portfolio returns and risk}

\section{Requirements to increase domestic portfolios may have implications for}

portfolio returns and risk. The Canadian experience with local investment rules illustrates some of the issues. In the province of Quebec, two major pension plans are required to invest at least 70 percent of their assets in Canada, with a dual mandate to: (i) provide strong returns for investors and (ii) promote the economic development of Quebec. ${ }^{8}$ The Caisse de Depot et Placement du Quebec (CDP) has been involved in several takeovers designed to retain Quebec ownership of important companies (a grocery firm in the late 1980s, and Le Groupe Videotron in 2001). Unfortunately, these investments resulted in substantial losses to the pension fund. At the same time, the pension funds expressed concern that the domestic investment requirements could contribute to a bidding up of Canadian asset prices and prevent adequate portfolio diversification.

\section{The World Bank finds that pension funds subject to unrestricted investment} regimes earned higher returns than those under more restrictive regimes. ${ }^{9}$ For example, during 1984-96, the average real pension return in Ireland, the Netherlands, the UK and the

\footnotetext{
${ }^{8}$ The Caisse de Depot et Placement du Quebec (CDP) is a pension fund operated by the province of Quebec, while the Canada Pension Plan Investment Board (CCPIB) provides pensions for Canadians who do not live in Quebec.

${ }^{9}$ See World Bank,. "Portfolio Limits: Pension investment restrictions compromise fund performance," in the World Bank Pension Reform Primer at www.worldbank.org/pensions.
} 
US was $9 \frac{1}{2}$ percent. By comparison, the average real return over the same period in the more tightly-regulated countries of Belgium, Denmark, Germany, Japan, Sweden, and Switzerland was $6 \frac{1}{2}$ percent. The difference was not due to national stock market performance, as average real stock returns were marginally higher in the more restrictive than in the less restrictive countries ( 4 percent vs. $3 \frac{1}{2}$ percent). Pension funds in the more liberal countries were somewhat more volatile, but an investor would have to be extremely risk adverse to want to forgo an additional three percentage points in average annual returns.

59. In Namibia, tighter domestic investment requirements could raise similar concerns about diversification, returns, and risk. A mandate to invest 5 percent of portfolio assets in unlisted companies implicitly assumes that there are sufficient investment opportunities to absorb the increased investment. If, however, the demand for such capital is low, and the prospects for new start-up companies is limited on account of factors other than availability of finance, then major new investments by pension and insurance companies would be possible only by moving into lower return or higher risk investments. The lack of reliable financial information for unlisted companies would also be a concern, particularly where pension funds have limited in-house capacity to differentiate between investment opportunities.

60. Experience with Namibia's Development Capital Portfolio (DCP) suggests these risks are applicable in the Namibia context. The DCP was set up by the government pension fund (GIPF) in 1995 to promote investment in domestic unlisted companies. The GIPF aimed to invest 5 percent of its assets under management in the DCP. However, a decade later the government concluded that the DCP had failed to meet expectations due to a lack of sound management (Bank of Namibia, 2005), and it was forced to write off 84 percent of the value of its investments in unlisted companies (N\$630 million of its N\$750 million investment). The GIPF is now investing in unlisted firms via venture capital firms and government institutions. It hopes these will be better able to monitor its investments.

61. Other developments suggest a limited pool of strong unlisted companies. Namibia Harvest Investments (NHI), an investment holding company that invested in asset management, unit trusts, a commercial bank, and an abattoir, raised N\$200 million in 1998 for venture capital but returned two-thirds of this money to investors in 2001 due to lack of investment opportunities (NEPRU, 2004).

\section{Modeling the new regulatory requirements}

62. The proposed new rules would require substantial new investments, stretching absorption and institutional capacities. If dual-listed companies are scored at 10 percent (rather than 100 percent) for domestic investment purposes, their contribution to the 35 percent domestic investment rule would fall from around 15 percent (currently) to $1 \frac{1}{2}$ percent. As a result, fund managers would need to shift at least $13 \frac{1}{2}$ percent of their portfolios out of foreign capital or dual-listed companies to finance new domestic 
investments. Moreover, if the new regulations cause the scoring of dual-listed companies to fall from 100 to 30 percent in the first year, the required shift of capital over the first 12 months would be equivalent to $10 \frac{1}{2}$ percent of total portfolios (Table III.5). With total portfolios more than 100 percent of GDP, the shift in assets could be significantly more than 10 percent of GDP.

Table III.5. Namibia: Impact of Tightening Domestic Investment Requirements

\begin{tabular}{|c|c|c|c|c|c|c|}
\hline & Current & Year 1 & Year 2 & Year 3 & Year 4 & Year 5 \\
\hline A. Domestic Status of Dual-Listed Companies & $100 \%$ & $30 \%$ & $25 \%$ & $20 \%$ & $15 \%$ & $10 \%$ \\
\hline Dual-Listed Companies (\% of Portfolio) $1 /$ & $15.0 \%$ & $15.0 \%$ & $15.0 \%$ & $15.0 \%$ & $15.0 \%$ & $15.0 \%$ \\
\hline Contribution to Domestic Investment Requirement (DIR) & $15.0 \%$ & $4.5 \%$ & $3.8 \%$ & $3.0 \%$ & $2.3 \%$ & $1.5 \%$ \\
\hline Asset Shift Need to Meet the DIR & $0.0 \%$ & $10.5 \%$ & $11.3 \%$ & $12.0 \%$ & $12.8 \%$ & $13.5 \%$ \\
\hline in N\$ Billions & $\$ 0.0$ & $\$ 7.6$ & $\$ 9.3$ & $\$ 11.4$ & $\$ 13.8$ & $\$ 16.7$ \\
\hline in percent of GDP & $0.0 \%$ & $11.8 \%$ & $12.8 \%$ & $13.9 \%$ & $15.0 \%$ & $16.2 \%$ \\
\hline B. Investment Requirement in Unlisted Namibian Companies & $0 \%$ & $5 \%$ & $5 \%$ & $5 \%$ & $5 \%$ & $5 \%$ \\
\hline Unlisted Companies ( $\%$ of Portfolio) $2 /$ & $1.5 \%$ & $2.2 \%$ & $2.9 \%$ & $3.6 \%$ & $4.3 \%$ & $5.0 \%$ \\
\hline New Investment in Unlisted Companies & $0.0 \%$ & $0.7 \%$ & $0.7 \%$ & $0.7 \%$ & $0.7 \%$ & $0.7 \%$ \\
\hline in N\$ Billions & $\$ 1.0$ & $\$ 1.6$ & $\$ 2.4$ & $\$ 3.4$ & $\$ 4.6$ & $\$ 6.2$ \\
\hline in percent of GDP & $1.7 \%$ & $2.5 \%$ & $3.3 \%$ & $4.2 \%$ & $5.1 \%$ & $6.0 \%$ \\
\hline \multicolumn{7}{|l|}{ Memo Items } \\
\hline Portfolio Assets (N\$ Billion) & 58.0 & 64.9 & 72.7 & 81.6 & 91.5 & 103.0 \\
\hline$\%$ of GDP & 111 & 112 & 114 & 116 & 118 & 120 \\
\hline GDP (N\$ Billion) & 52.2 & 58.0 & 63.8 & 70.3 & 77.5 & 85.8 \\
\hline
\end{tabular}

1/ Assuming no portfolio shift away from dual listed companies.

2/ Assuming 5-year phase-in of 5\% requirement.

63. Where would these repatriated assets be invested? Some would be invested in unlisted companies to move toward the proposed 5 percent minimum requirement. Since unlisted companies currently make up about $1 \frac{1 / 2}{2}$ percent of pension fund assets, a further shift into such companies of $3 \frac{1}{2}$ percent of fund assets would be needed, though the time scale for this adjustment is not clear. The remaining part of the overall shift in assets would be split between listed Namibian equities, government bonds, cash, or other investments (such as property).

64. Namibia's capacity to absorb these investments could be an issue, particularly in the short run. Capital inflows equivalent to $10^{1} / 2$ percent of GDP would likely result in considerable inflationary pressures (and associated real exchange rate appreciation) unless phased in over a large number of years. Indeed, the inflationary risks would be particularly marked. In addition, the capital inflows would add to the upward pressures that Namibia's real exchange rate already faces, as a result of record levels of SACU receipts and high mineral exports. 
65. Institutional capacity is also a concern. With only 7 locally-listed firms, the Namibian stock exchange cannot be expected to intermediate large new investments to this sector. Similarly, with the government budget close to balance in the short-term, the supply of government debt is not expected to rise substantially. Given these considerations, the risks of asset price inflation would appear high. Even if funds were able to carve out safe investments in domestic bonds and cash (possibly crowding out banks), their returns would likely be lower than in their current foreign equity holdings, reducing returns to savers.

\section{Incentives for market development}

66. It is unclear what effect tightened domestic investment requirements will have on the development of Namibia's capital market. The government securities market is already well-developed, with active secondary trading in Treasury bills. ${ }^{10}$ In the face of limited supply on account of relatively small government deficits, excess demand may develop, which could diminish secondary market liquidity and force a scarcity premium, reducing bond yields. This has been the experience in Chile, where pension fund assets are growing much faster than the stock of high quality bonds.

\section{The impact of tightened domestic investment requirements on the Namibia} Stock Exchange (NSX) is hard to predict. With incentives for new investments in both listed and unlisted domestic companies, the net incentives to list is unclear. However, it is clear that the incentives will decline for the 19 existing dual-listed companies, which account for approximately 95 percent of market capitalization. If a portion of the latter delist, capitalization of the NSX could decline.

\section{Policies to Encourage Financial Flows to Namibia}

68. Given the risks associated with a regulatory approach to strengthening domestic investment, market-based options are explored below.

\section{Broadening the range of investable assets}

69. To attract greater domestic investments, a broader pool of investments would be an advantage. Options would include mortgage securitization, development of the public agency and corporate bond market, securitization of funding of existing public enterprises, and development of the factoring and leasing sector.

\footnotetext{
${ }^{10}$ Outstanding government securities amounted to 22 percent of GDP in mid-2007.
} 


\section{Mortgage securitization}

70. Since a great deal of wealth is tied up in property, mortgage securitization can provide access to a new asset class for institutional investors. In many developing countries, housing finance is relatively expensive and rationed. Pension and insurance funds provide a potentially large source of funding for housing. Because they have long-term liabilities these funds can, in theory, manage the liquidity risk of housing loans more effectively than depository institutions that rely on short-term funding. However, mortgage securitization requires a strong legal and institutional infrastructure and well-developed primary mortgage markets. In addition, there must not only be demand from institutional investors but willingness by lenders to seek access to the capital markets to manage capital and risk. In many cases, funding through deposits may be less expensive for banks than funding through mortgage securities. Thus, mortgage securitization may not be attractive for banks with access to low cost deposits.

71. The government can perform an enabling role in promoting mortgage securities. Most importantly, the government can create and maintain a strong legal system that supports collateralized lending. It could also accept mortgage-backed securities as collateral at the central bank discount window.

72. The experiences of emerging markets carry several lessons for the development of mortgage backed securities markets (Box 1). It is important to gain investor acceptance and build a strong legal and regulatory framework. While government backing and privileges (e.g., acceptance at the central bank window and discounted risk weightings) can help develop the market, subsidization makes the schemes more expensive and hinders the development of private sector markets. Excessive liquidity can also make commercial banks reluctant to sell mortgages to mortgage security intermediaries.

73. Namibia appears well placed to develop a mortgage backed securities market. Namibia's financial market is relatively sophisticated and well regulated. Banks have a high concentration of assets in residential mortgages, which may create an incentive for diversification through securitization. In addition, Namibia is closely tied to South Africa which has already has a market for mortgage securities. This should make it easier to develop products and tap expertise in the development of this market. 


\section{Box III.1. Experiences with the Introduction of Mortgaged Backed Securities Markets}

Several emerging markets have introduced mortgage securities with mixed results. In Chile and Malaysia, mortgage securities markets have been relatively successful and helped to promote housing finance. In Hong Kong and Hungary, mortgage securities helped to fund the housing market but circumstances have led to problems in implementation.

- Chile: As in Namibia, pension and life insurance funds became major investors. Mortgage securities became popular because of the lack of alternative investments. Pensions funds were initially not allowed to invest in stocks, the budget had been in surplus reducing the supply of government debt, and fixed income investments had the disadvantage to require ratings from at least two agencies. Partly as a result, in recent years about 70 percent of mortgage financing in Chile has come from mortgage securities; these securities now make up about 15 percent of pension fund portfolios.

- $\quad$ Malaysia: In 1987, the Malaysian government created the Cagamas Berhad. Cagamas purchases mortgage loans from mortgage originators at fixed or floating rates for 3 to 7 years. Its debt is rated AAA by the Malaysian rating agency and carries a risk weighting of 10 percent, compared with a 50 percent rating for housing loans. In Malaysia, Cagamas has successfully provided liquidity to mortgage lenders, reduced market risks, and helped develop private fixed-income markets.

- Hong Kong: The Hong Kong Mortgage Corporation (HKMC) was established in 1997 to reduce real estate asset concentration and stimulate the development of the housing market. At end-2002, the HKMC was responsible for 5 percent of outstanding residential mortgages and 7 percent of the corporate debt market. However, the development of Hong Kong's mortgage backed securities market has been hampered by excess liquidity which makes commercial banks reluctant to seek wholesale funding. Institutional investors have also been reluctant to invest in the market due to their short-term bias. The government attempted to address these concerns by allowing government housing agencies to sell mortgages to the HKMC. While this increased the HKMC's portfolio of mortgages, it also meant that the HKMC effectively became a government funding mechanism instead of a method to promote development of the private mortgage market.

- Hungary: The government created a mortgage bond market in 1997. There are three mortgage banks of which the largest is government owned. However, the government provides subsidies for loans less than Euro 380,000. Thus, the lending rate for mortgages is less than the yield on treasury bonds. The subsidy causes several problems. The subsidy is not targeted and does not leverage private or government spending. In addition, below market interest rates prevent the development of a private sector mortgage market. 


\section{Development of the public agency and corporate bond market}

74. Development of the corporate bond market could provide additional assets for domestic investment and improve the functioning of Namibia's financial markets. As countries develop, firms typically go through a number of stages with regard to financing needs. Initially, firms rely on self-generated funds. Later, they rely on lending from banks. Finally, as they become larger firms can rely on direct financing through corporate debt and equity markets. By moving to this last stage, firms diversify their capital structure, spread risks, and promote competition.

75. While Namibia has a large government bond market, development of the corporate bond market has lagged. As of end-2006, the value of all bonds outstanding on the Namibia Stock Exchange was N\$8.2 billion. Of this amount, government bonds accounted for 82 percent, commercial bank bonds (Bank Windhoek, First National Bank, and Standard Bank) for 9 percent, and state owned enterprise bonds (Nampower and the Road Fund) for 8 percent. As of end-2007, the value of corporate and public enterprise bonds was approximately 4 percent of GDP. Given this relatively low level, there appears to be room for additional development of the local corporate bond market.

76. The government's foremost role should be to ensure that the legal and regulatory infrastructure promotes growth of the corporate bond market. This includes maintaining a well functioning clearing and settlement system; a regulatory structure that provides for adequate disclosure, accounting standards, and corporate governance; the availability of credit rating agencies; and a clear policy with regard to corporate bond market development. ${ }^{11}$ Namibia already has many of these elements, including a well-functioning legal system and regulatory structure, but some fine-tuning may provide additional benefits.

\section{In addition, the government could provide a catalyst by encouraging credit} worthy public enterprises to issue local currency bonds. Nampower's successful issuance of N\$500 million in 13-year corporate bonds provides an illustration. This was the first of what is expected to be a total issuance of $\mathrm{N} \$ 3$ billion in bonds to fund infrastructure investment. The bond was oversubscribed by 70 percent and priced at 105 basis points above the year 2020 South African government bond. This indicates that there is demand for local currency bonds backed by credit-worthy borrowers.

78. Yet, such efforts would need to be carefully implemented to avoid increasing the contingent liabilities to the government. Only public enterprises that have reliable income streams and good credit should be allowed to borrow. In addition, the government should also make clear that such bonds are not implicitly backed by a government guarantee.

\footnotetext{
${ }^{11}$ For an additional discussion of the challenges of developing local corporate bond markets see Luengnaruemitchai and Ong (2005).
} 


\section{Privatization}

79. The limited number of listed domestic companies could be broadened by diversifying the ownership of public enterprises. In 2006, the government successfully sold 34 percent of the mobile phone provider MTC, raising N\$648 million in public funds. Ownership diversification could contribute to broadening the equity market, and to the extent that investment opportunities strengthen under private management, the demand for financing would progressively increase.

\section{Factoring and leasing}

80. Promoting factoring and leasing could also help develop the non-government securities markets. Factoring and leasing companies could fund their operations by issuing commercial paper or medium-term bonds. This would expand the financial markets by providing additional investment opportunities for investors. At the same time, factoring and leasing companies can improve access to finance by providing funds to small and medium enterprises that have trouble qualifying for traditional forms of finance.

\section{Private equity}

\section{Another potential method to promote investment in Namibia is through} development of a private equity market. Private equity can provide an alternative vehicle for institutional investment and deepen Namibia's financial markets. Private equity also has the potential to fill a gap in the capital markets for firms that have outgrown family or selffinancing but whose risk profile is not attractive to banks or securities markets. In addition, experienced private equity investors can provide management expertise that enhances firm value. For investors, private equity provides another asset class that enhances diversity and has the potential for high returns.

82. In some developing countries the promise of private equity has not been fulfilled; in this respect, proper regulation and implementation is crucial. Three main areas have been of concern: (i) the quality of information available to investors, (ii) regulatory and legal standards, and (iii) the ability of investors to exit. For private equity markets to work well, firms must provide accurate and timely information to investors on both operations and financing. These must be provided not only at the initial investment stage but on an ongoing basis so that investors can monitor fund performance. In some cases, entrepreneurs are not used to providing such information or are reluctant to subject themselves to the judgments of outsiders. This can hinder the development of private equity markets.

\section{It is also important to provide a sound legal and regulatory environment for} private equity investments. When investors do not have direct control over the firms in which they invest, they need access to a legal system that can enforce contracts if there are disputes. Thus, the development of a strong private equity market requires statutory 
protection for minority shareholder rights. Without such systems, private equity investors can suffer serious losses or avoid investments altogether.

84. Finally, development of private equity markets requires a method for investors to exit profitably. Exits usually take the form of initial public offerings, sales to strategic investors, or management buyouts. In mature markets, initial public offerings have been the dominant method for investors to exit private equity and such exits tend to be more profitable than strategic or management buyouts. In developing countries, it has been more difficult to carryout initial public offerings.

\section{Strengthening the business sector}

85. On a parallel track, efforts can be made to strengthen returns on investments in Namibia. Where the business environment and Namibia's comparative advantages offer high rates of return, these will be competitive with foreign investments in attracting financing. The challenge is to identify the aspects of the business environment that are open to improvement through government policies.

86. Namibia has many strengths as a location for business. The World Bank's Doing Business 2008 survey ranked Namibia 43 out of 178 countries, with Namibia rated positively by businesses in regard to the licensing framework, enforcing contracts, and credit availability. Slightly less favorably, the World Economic Forum's Global Competitiveness Report 2007-08 rated Namibia 89 out of 131 countries, yet with strong ratings for the macroeconomy, infrastructure, and institutions.

87. There are no guaranteed steps to a more attractive business climate. Surveys of the business environment produce different results depending on their design and their survey populations. Thus, each country needs to work with businesses to identify local bottlenecks and disincentives. In Namibia's case, a place to start might be the World Bank's recent Foreign Investment Advisory Service (FIAS) assessment, which suggested that Namibia focus on labor skills and protection for property rights. It suggested that Namibia's foreign investment law is outdated and should be replaced as it no longer plays a meaningful role in investors' decisions. It also found that special business incentives have not been effective and a simpler and less discretionary regime with a lower corporate tax rate would be preferable. Steps to improve the quality of education and make the labor market more flexible would also be helpful (see Chapter V).

88. An additional priority is to make existing investments more productive. Since Namibia's domestic investment ratio of around 27 percent is already above the average of 25 percent for lower middle-income countries, higher total returns may not come from further increases in the investment ratio, but from making existing investments more productive. This again comes back to the investment climate, as well as to the merits of extending the privatization program. 


\section{E. Conclusion}

89. Summarizing the above discussions, the staff would offer the following observations on the planned tightening of Namibia's domestic investment requirements:

- Similar (and even higher) requirements are applied in other countries. However, in many cases, these rules are driven by prudential concerns about exchange rate exposure, which do not apply in Namibia's case;

- Where countries have adopted tight domestic investment requirements, this has often been at the expense of rates of return and the risk profile. In cases, it has also encouraged politically-motivated investment decisions that proved financially costly. Thus, steps should be taken to make sure that there are sufficient assets to meet the demand generated by such requirements and projects are adequately screened;

- Domestic investment rules do not necessarily promote financial market deepening. Financial markets work best with a balance of willing buyers and sellers. Where the supply of finance is artificially increased, this can actually distort yields and retard market development. The impact on the Namibian stock exchange is particularly unclear given the competing incentives for local companies to list or remain unlisted, and the clear loss of incentive for the larger foreign companies to remain listed;

- $\quad$ Tighter domestic investment rules will not necessarily reduce capital outflows. The proposed regulations can be readily circumvented (and thus offset) by private individuals and banks, resulting in financing flows that are less easily monitored. Moreover, if markets perceived the regulations as an effort to persuade capital to remain in the country, it could have perverse effects;

- The phasing and macroeconomic impact of regulatory changes require careful scrutiny. The proposed rules would, if strictly enforced, require a large, short-run repatriation of capital. In all likelihood, this would be inflationary (for asset prices, and for the underlying investments) and fuel pressures for real exchange rate appreciation. Given the high levels of foreign currency inflows from mineral exports and the SACU regime, the timing of the proposed capital repatriation does not appear opportune;

- Market-based incentives for investment repatriation are attractive. Because they would be associated with the development of new patterns of financial intermediation (mortgage financing, factoring and leasing, etc), they would likely channel investments to areas of unmet demand for financing, thereby reducing inflationary risks; 
- A strengthened business environment would also serve the interest of pension and insurance clients. By raising the rate of return on domestic investments, funds could invest in the local market without undermining the real return on their clients' savings, a criterion for successful continued growth of the sector; and

- Namibia's investment ratio is already high, and one priority is to make more of these existing investments. This suggests reforms to further strengthen the domestic investment climate, as well as to diversify ownership of public enterprises. 


\section{REFERENCES}

Alfaro, Laura; Sebnem Kalemli-Ozcan; and Vadym Volosovych, "Why Doesn't Capital Flow from Rich to Poor Countries? An Empirical Investigation,” NBER Working Paper No. 11901, December 2005.

Chiquier, Loic; Olivier Hassler; and Michael Lea. "Mortgage Securities in Emerging Markets,” World Bank Policy Research Working Paper No. 3370, August 2004.

Bank of Namibia. Quarterly Bulletin June 2007, Vol. 16, No. 2.

Bank of Namibia. "Private Equity: Lessons for Namibia.” BON Occasional Paper 2/2005.

Bank of Namibia. Review of the Domestic Asset Requirements (Regulation 28 and 34). Research Department, December 2003.

Foreign Investment Advisory Service. Namibia Investment Legislation, Incentives, and Institutions: Recommendations for Reform. December 14, 2006.

Lewis, Karen K. "Trying to Explain Home Bias in Equities and Consumption," The Journal of Economic Literature, Vol. 37, No. 2 (Jun., 1999), pp. 571-608.

Lucas, Robert. "Why Doesn't Capital Flow from Rich to Poor Countries?”, American Economic Review, May 1990, Vol. 80, pp. 92-96.

Luengnaruemitchai, Pipat and Li Lian Ong. "An Anatomy of Corporate Bond Markets: Growing Pains and Knowledge Gains,” IMF Working Paper 05/152.

Namibia Economic Policy Research Institute (NEPRU) and the Institute for Public Policy Research (IPPR). The Namibian Stock Exchange and Domestic Asset Requirements: Options for the Future. NEPRU Research Report No. 26, March 2004.

Prasad, Eswar; Raghuram Rajan; and Arvind Subramanian. "The Paradox of Capital", Finance and Development, International Monetary Fund, March 2007. 


\section{Management of Non-Renewable Natural ResourCes ${ }^{12}$}

\section{A. Introduction}

90. Although Namibia's mineral sector is smaller-relative to GDP — than in many African economies, the impact on income levels, exports, and the financing of the budget are important. Many mineral-rich economies have suffered a so-called "resource curse", with stagnating or declining real incomes. The evidence so far is that Namibia has avoided this problem, achieving lower-middle income status and relatively strong real income growth. Nonetheless, it is useful to take stock of Namibia's success in managing its mineral wealth, highlight steps that Namibia could take to further consolidate resource management, and draw lessons for other countries.

91. This paper reviews a number of issues related to Namibia's management of nonrenewable natural resources. This includes an examination of the importance of nonrenewable natural resources to the Namibian economy, how Namibia's tax and legal regime compares with international standards, and how the authorities can maintain long-term fiscal and macroeconomic sustainability in the face of volatile natural resource income. The paper finds that non-renewable natural resources are a significant contributor to Namibia's economy, though less than in other natural resource producers. Namibia's legal framework for resource exploitation and mineral taxation arrangements are generally in line with international standards and could be regarded as an example to other producers. With regard to the long-term fiscal and macroeconomic sustainability, this paper does not see merit in a dedicated mineral fund to accrue mineral revenues, nor does Dutch disease appear a risk.

\section{B. Overview of Namibia's Mineral Sector}

\section{Non-petroleum resources}

92. Namibia is well endowed with non-renewable natural resources including diamonds, uranium, zinc and gold. These minerals have made an important macroeconomic contribution. Since independence in 1990, mineral exports have averaged 21 percent of nominal GDP and 57 percent of total exports. Similarly, taxes and royalties on minerals have averaged $7 \frac{1}{2}$ of central government revenues. However, mineral extraction is capital intensive and the direct contribution to employment has been modest. The Chamber of Mines estimates total mining sector employment in 2004 at less than 7,500 (around 2 percent of total employment).

93. Diamonds are Namibia's most significant mineral resource, accounting for 70 percent of total mineral exports. Namibia produces more than 2 million carats of gemquality diamonds a year. Since independence, diamond exports have averaged $14 \frac{1}{2}$ percent

\footnotetext{
${ }^{12}$ Prepared by Lawrence Dwight (AFR).
} 
of nominal GDP and 39 percent of the value of total exports while taxes and royalties on diamonds have averaged $6 \frac{1}{2}$ percent of central government revenues. In recent years with the depletion of land-based mines, marine mining of diamonds has become more important. Almost half of total production was recovered at sea in 2006.

\section{Over 90 percent of Namibia's diamonds are produced by Namdeb, a 50-50 joint} venture between the government and DeBeers. DeBeers has agreed that Namdeb will make 16 percent of its production available for local polishing and cutting. Aside from Namdeb, other diamond operators include Diamond Fields International and Samicor. Apart from diamonds, the most important minerals in order of importance are uranium, zinc, gold, and copper (Figure IV.1). Mining for these and other minerals is conducted by the private sector. $^{13}$

Figure IV.1. Namibia: Composition of Mineral Exports, 2006 (US\$ Value)

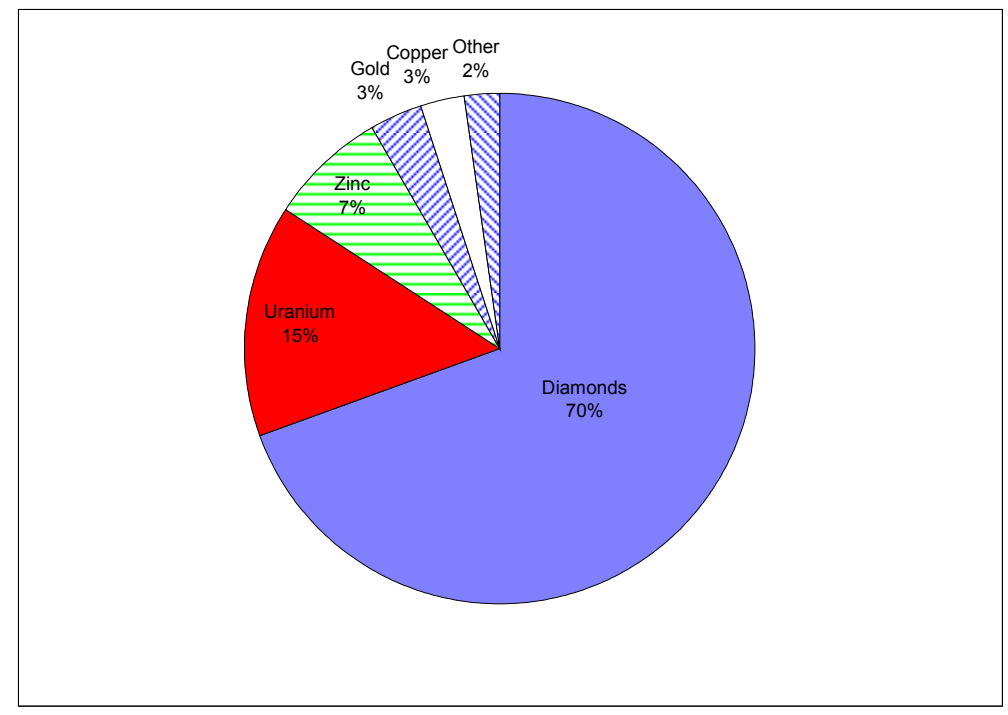

\section{Petroleum resources}

95. Gas production may become important in the future. The Namibian government has plans to develop the Kudu offshore natural gas field, which holds 1.3 trillion cubic feet of proven gas reserves. This is enough gas to power a planned 800-megawatt electricity plant for more than 20 years. The total cost of the project is expected to be US\$1 billion dollars.

\footnotetext{
${ }^{13}$ The six major producers are: Rössing Uranium, which operates the Rössing mine; Anglo American, which operates the Skorpion zinc mine; Namzinc, a zinc refinery; Rosh Pinah Zinc, which operates the Rosh Pinah zinc and lead mine; Ongopolo, which operates three copper mines and a copper smelter; AngloGold Ashanti Namibia, which operates the Navachab gold mine; and Okorusu Fluorspar, which operates the Okorusu mine.
} 
The government included N\$750 million (US\$125 million) in its medium-term economic framework (MTEF) to pay for infrastructure related to Kudu, and Nampower recently issued N\$500 million (US\$ 71 million) of a planned N\$3 billion bond to pay, in part, for the Kudu project. Production is expected to begin in 2010 but due to the complexity of the project could be delayed.

96. The National Petroleum Corporation of Namibia (Namcor) is a state-owned enterprise that imports oil. While Namibia does not currently produce natural gas or oil, private sector oil companies are required to source 50 percent of their oil from Namcor. The remaining 50 percent may be imported directly.

\section{Namibia's Institutional Framework for Resource Exploitation}

\section{In many countries, resource exploitation has failed to deliver improved living} standards. Studies attribute this "resource curse" to rent-seeking behavior and the misallocation of natural resource revenues, with adverse consequences for productivity and growth. Moreover, as natural resources can provide a source of income independent from citizens, it can make a government less accountable to the public. Effective avoidance of rent-seeking behavior requires a rule-based, transparent legal, regulatory, and tax regime for mineral exploration and extraction, transparent operation of state-owned enterprises, inclusion of mineral revenues in the budget, and good governance in both the public and private sector.

98. In practice, Namibia has relatively strong public institutions. Minerals in Namibia are not produced in a competitive environment due to scale economies and the licensing regime. However, according to Transparency International, Namibia had the fifth lowest level of corruption among 45 countries surveyed in Africa in 2006. The 2005 World Economic Forum's Global Competitiveness Report ranked Namibia 53 out of 131 countries on public institutions, with judicial independence ranking 34 and property rights ranking 41 .

\section{The regulatory regime for mineral exploration and extraction}

99. Namibia's legal framework for natural resource exploitation was reviewed by the Fund in 2006. ${ }^{14}$ The review concluded that Namibia's Minerals Act and Diamond Act (Box IV.2) are in line with international best practice. Namibia was assessed to have the essential elements of a transparent fiscal system - including a transparent legal and administrative framework for budget preparation and execution - and meet the basic standards of the IMF's fiscal transparency code. In this respect, the review concluded that Namibia could provide an example of best practice to other countries in the region. To further strengthen openness of the fiscal regime, consideration should be given to

\footnotetext{
${ }^{14}$ Emil Sunley, Taimur Baig, and Philip Daniel. "The Fiscal Regime for Mining and Processing”, FAD TA Report, April 2006.
} 
participation in the Extractive Industry Transparency Initiative (EITI), particularly given the likely growth of new investments in the uranium and natural gas sectors. ${ }^{15}$

\section{Nonetheless, the review did recommend additional technical changes to} Namibia's regime for natural resources. These include recommendations that the authorities improve their budget classification structure, increase the availability of information to the public, improve audit capacity, and upgrade the supervision of parastatals. The review concurred that the Minister of Mines should have the authority to make regulations and narrow the scope of mineral agreements. It recommended, however, that royalty rates be enacted into law and not left to the discretion of the Minister. The review also found that Namibia may benefit from fiscal stability clauses in mining contracts to provide additional assurance to investors. Finally, the review argued that mineral processing that occurs in Economic Processing Zones (EPZ) should receive customs but not income tax relief to discourage abuse of the EPZ system.

\section{The tax and royalty regime}

\section{Namibia has different tax rates for mining and non-mining companies. A} 55 percent corporate profit tax is applied to diamond companies. This compares with a 37.5 percent profit tax for non-diamond mineral companies and 35 percent for ordinary, nonmining corporations. A 10 percent royalty is imposed on the value of rough diamond exports and the government is considering a royalty of up to 5 percent on non-diamond mining companies. For the purposes of taxation, the government does not make a distinction between local and foreign-owned companies nor among types of non-diamond minerals.

Namibia's natural resource taxation regime was reviewed by the Fund in 2006. ${ }^{16}$ The review concluded that Namibia's mineral tax regime is in line with international practice. It recommended that the royalty rate remain at 10 percent for diamonds and the government set at 2-3 percent royalty rate for other hard minerals. However, the 10 percent royalty for diamonds should apply to all diamonds produced in Namibia (not just to exports). With regard to taxation, the review recommended corporate tax rates remain unchanged, i.e., 55 percent for diamond mining companies and 37.5 percent for other mining companies. On transparency, the review recommended that diamond and other mining agreements be made public.

\footnotetext{
${ }^{15}$ Namibia currently participates in the Kimberley Process diamonds initiative.

${ }^{16}$ Ibid.
} 


\section{Box IV.1. Namibia: The Legal and Regulatory Regime for Minerals}

The legal basis for Namibia's non-renewable natural resource sector is embodied in two major laws: the Minerals Act of 1992, and the Diamond Act of 1999.

The Minerals Act: This Act replaced a series of laws inherited from the pre-independence period. It vests all rights related to the exploitation of Namibia's mineral resources in the State. The Act charges the Ministry of Mines and Energy (MME) with regulation and oversight of the mining industry. Recently, the government has proposed amendments to the Minerals Act to give the Minister the power to make regulations and set general royalty rates. However, these amendments would leave the basic framework for mining unchanged.

Rights to prospecting and extraction are provided through exclusive prospecting and mining licenses. An exclusive prospecting license gives the holder the right to prospect a designated area of up to $1000 \mathrm{~km}^{2}$ for up to three years with the possibility of two two-year extensions. A mining license gives the holder the exclusive right to develop and operate a mine for 25 years with the possibility of a 15 year extension. To obtain a mining license an applicant must show that it has the technical expertise and financial backing to develop and operate the mine. Licenses are awarded on a first come, first served basis and applications are evaluated in accordance with the Minerals Act. The MME has the power to grant or refuse mineral licenses, and is advised on this matter by a Mining Commission. Members of the mining industry are represented at the MME through a Minerals Board that advises the Minister. The Board includes representatives of the MME, the Chamber of Mines, and small scale operators.

The Diamond Act regulates the production, ownership and trade of rough and polished diamonds and establishes a system of permits and licenses. It does not replace or substitute for the Minerals Act but creates additional classes of licenses necessary for diamond mining and other value added activities. One section of the Diamond Act (Section 58) allows the Minister of Mines and Energy to require diamond producers to make rough diamonds available to Namibian diamond cutters and polishers. This provision has never been invoked. However, DeBeers recently agreed that 16 percent of Namdeb's annual production would be made available for local polishing and cutting. Another section of the Diamond Act (Section 59) gives the Minister of Mines and Energy the power to require producers to sell up to 10 percent of annual rough diamond production on the international market. This provision is designed to allow the government to test prices of unpolished diamonds. The Diamond Act also establishes a Diamond Board headed by a Diamond Commissioner and comprised of representatives from the Ministries of Mines and Energy, Finance, and Fisheries as well as diamond producers and diamond cutters.

102. With regard to the treatment of mineral revenues, the review found the fiscal regime for the mining sector is clearly stated and comprehensive. All licensing fees, taxes and royalties go directly to the state revenue account and are included in the budget. However, a three percent royalty goes to the Diamond Valuation Fund and 0.05 percent of producer sales go to the Diamond Board Fund. Both of these funds are not reflected in the budget. 
103. Going forward, the tax regime may need to be reviewed to ensure that the budget benefits appropriately from the recent high rents in the mineral sector. At the same time, some sector are of growing importance (uranium and, potentially, natural gas), and the tax regime will need to remain abreast of these changes.

\section{Public expenditure management}

104. As mineral revenues are not separated from general revenues, expenditures based on mineral revenues cannot be separated from general expenditures. Thus, effective use of mineral resources depends upon strong institutions and an accountable government. On these measures, Namibia performs relatively well. Namibia has transparent legal and administrative framework for the budget, information on the Medium Term Expenditure Framework (MTEF) is available to the public, government procurement is subject to internal and external audit, and the government is implementing a system to provide information on budget execution.

\section{The last public expenditure review (PER) occurred in 1994 and covered} Namibia's budget, tax, and expenditure regimes. It found that Namibia's tax system is relatively sound. Although some time has passed since that report, many of the issues remain relevant. The PER found that Namibia has an appropriate balance between direct and indirect taxes. However, there is a significant dependence on Southern Africa Customs Union (SACU) receipts, which make up approximately one third of total revenues. The PER recommended efforts to develop a VAT system and improve tax administration. On the budget and expenditure side, the PER found the budget system is modern and relatively comprehensive. To improve the effectiveness of public expenditures, it recommended improving financial control and accountability, strengthening the evaluation of projects, and increased coordination between the general and development budgets. The report noted that parastatals operate relatively independently and there is an argument to be made for privatization as a way to reduce their drain on the budget.

\section{Going forward, implementation of program-based budgeting would improve} accountability and help prioritize government expenditures. Currently, the medium-term economic framework (MTEF) uses a program classification. However, expenditure data are reported only by line ministry. Thus, there is a need to modernize the budget classification structure and chart of accounts to facilitate informed discussion of policies and to rationalize spending.

\section{Operation of state-owned enterprises}

107. No fully state-owned enterprises operate in the natural resources sector. One state-owned enterprise (Namcor) imports oil. Government involvement in the mining sector is carried out solely via equity investments in three mining companies: Namdeb (50 percent share), DeBeers Marine Namibia (30 percent share) and Rössing Uranium (3 percent share). However, government participation is limited to management with no operational 
involvement. All other companies in the mining sector are private. However, the government receives payments from these companies in the form of taxes and royalties (and in the case of equity participation through profit sharing and dividends). All these sources of funds are included in the central government budget.

\section{Governance requirements for the private sector}

108. Namibia's accounting requirements for the private sector are comprehensive and in accordance with international accounting standards. Natural resource companies are subject by law to the same internal controls and auditing standards as other companies. In particular, mineral producers prepare audited accounts that are produced within six months of the close of the financial year. These accounts cover subsidiaries and are made available to the public annually. However, mining contracts, including those of Namdeb, are not available to the public.

109. In summary, Namibia has set high standards with regard to establishing a rulebased, predictable institutional framework for mineral sector. Technical experts have recommended only two small changes with respect to the revision of the Minerals Act, i.e., the Minerals Act should define the royalty rates for minerals and should limit the discretionary powers of the Minister of Mines and Energy.

\section{Fiscal Management of Natural Resource Earnings}

110. Natural resources pose several fiscal management issues. First, how to manage spending in the face of potentially volatile receipts. Second, issues of long-term fiscal sustainability. Third, how to set appropriate spending levels given the finite nature of resource earnings. These are considered in turn.

\section{Managing volatility in Namibia's resource earnings}

\section{Natural resource revenue volatility is commonly associated with global price} changes. In Namibia's case, however, the U.S. dollar price for rough diamond exports, its main mineral export, has been broadly stable since 1995 (Figure IV.2). For other minerals, prices have risen sharply since 2005, but output and contributions to government revenues remain relatively modest. As a result, export fluctuations have hisorically been driven by changes in output, particularly in the diamond sector (Figures IV.3 and IV.4). 
Figure IV.2. Namibia: Mineral Export Prices, 1995-2006

$(1995=100)$

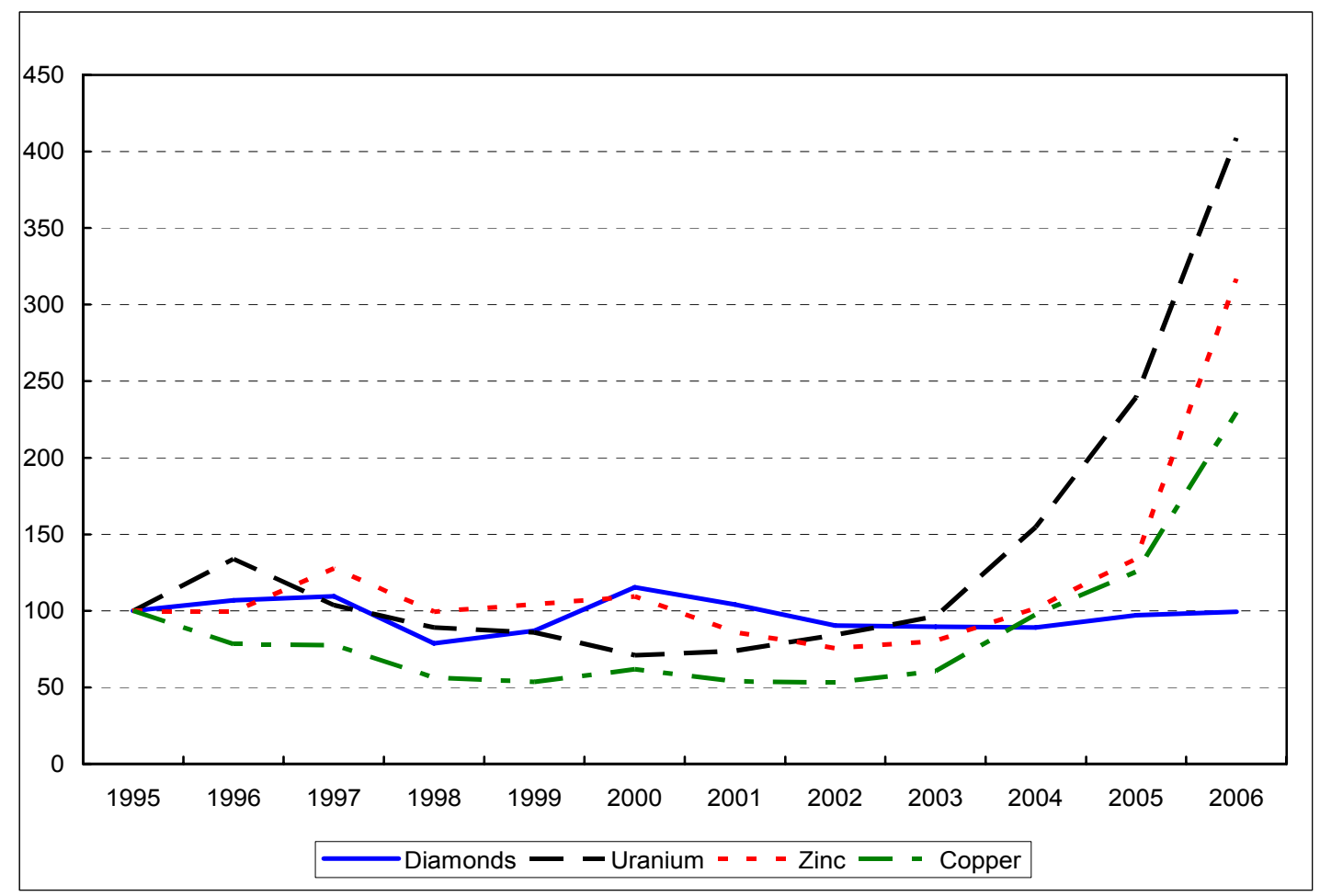

Figure IV.3. Namibia: Mineral Production Volatility, 1990-2006

(Percent Change)

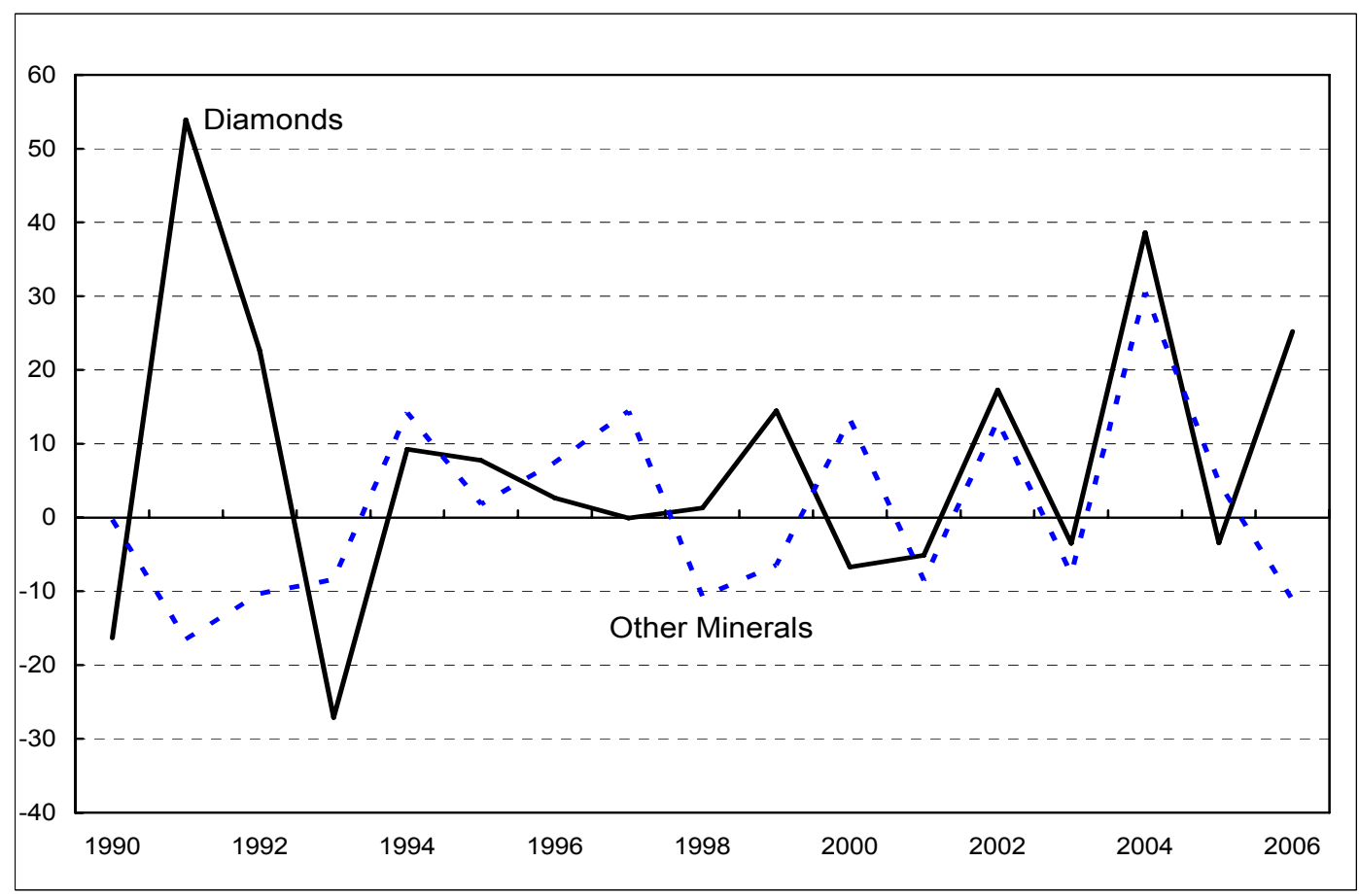


Figure IV.4. Namibia: Mineral Exports and Production, 1990-2006

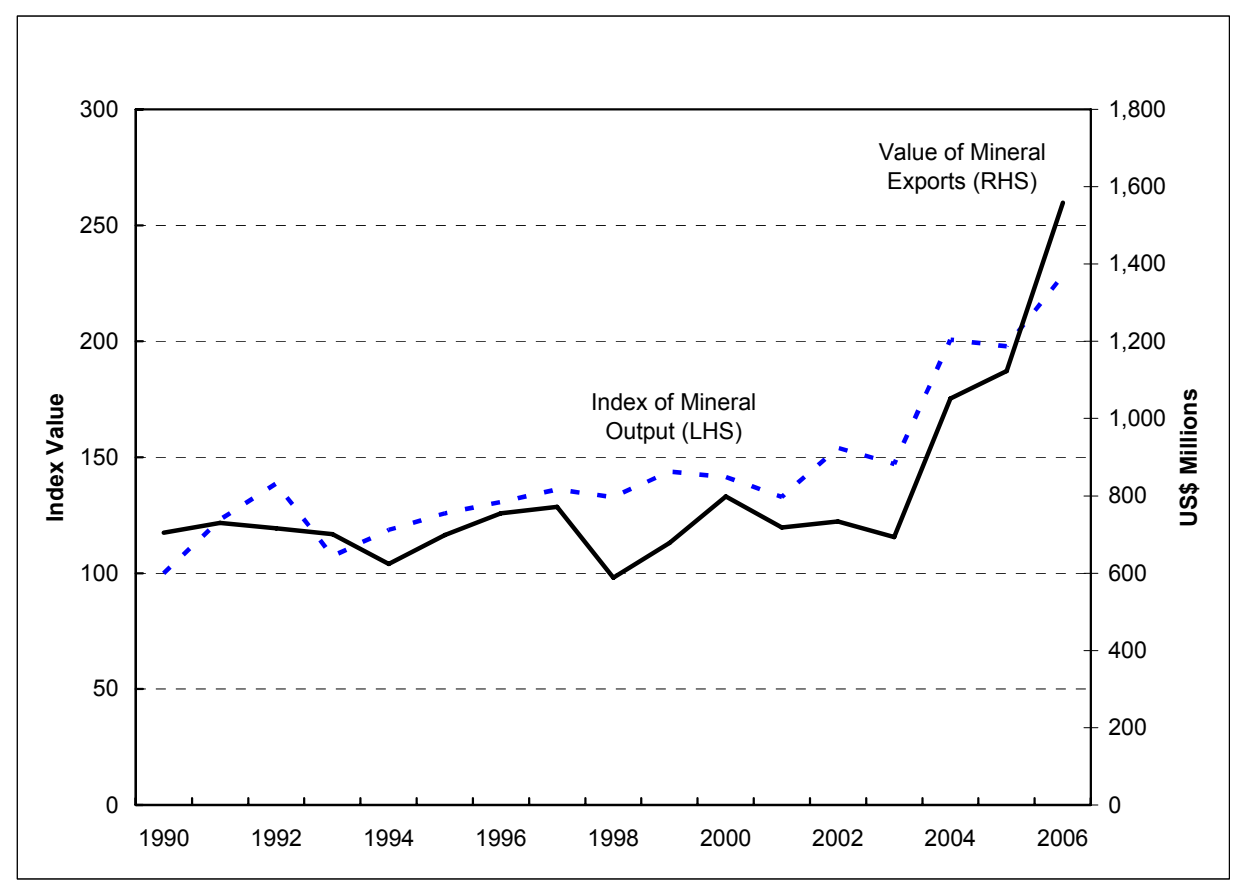

112. The mineral sector is small in Namibia, compared to many African economies. In Angola, for example, oil and gas exports averaged 65 percent of GDP, contributing fiscal revenues of 34 percent of GDP over the last ten years (Table IV.1). Similarly, diamonds have been a much larger factor in the Botswanan economy than for Namibia. Following from this, the volatility of mineral export receipts and fiscal contributions are larger than in Namibia's case.

Table IV.1. Resource Sector Volatility in African Countries, 1997-2006

\begin{tabular}{lccccc}
\hline Country & $\begin{array}{c}\text { Main mineral } \\
\text { export }\end{array}$ & $\begin{array}{c}\text { Mineral } \\
\text { exports }(\% \text { of } \\
\text { GDP) }\end{array}$ & $\begin{array}{c}\text { Standard } \\
\text { deviation of } \\
\text { exports }\end{array}$ & $\begin{array}{c}\text { Mineral } \\
\text { revenues }(\% \\
\text { of GDP) }\end{array}$ & $\begin{array}{c}\text { Standard } \\
\text { deviation of } \\
\text { revenues }\end{array}$ \\
\hline Namibia & Diamonds & 14.7 & 2.1 & 2.5 & 1.2 \\
Botswana & Diamonds & 32.8 & 4.2 & 20.5 & 3.4 \\
Cameroon & Oil & 8.3 & 2.0 & 4.8 & 1.3 \\
Gabon & Oil & 27.0 & 7.2 & 18.9 & 2.9 \\
Angola & Oil & 64.7 & 8.6 & 34.0 & 6.7 \\
\hline
\end{tabular}

Source: IMF staff estimates.

\section{Exchange rate fluctuations have been an important source of volatility in}

Namibia. The peg to the South African rand has given rise to significant currency movements. Thus, depreciation of the rand boosted diamond taxes and royalties to 5 percent of GDP in 2002/03, before falling to 2 percent of GDP in 2004/05 as the currency strengthened. 
Figure IV.5. Namibia: Mineral Tax Revenues and the Exchange Rate, 1990-2006

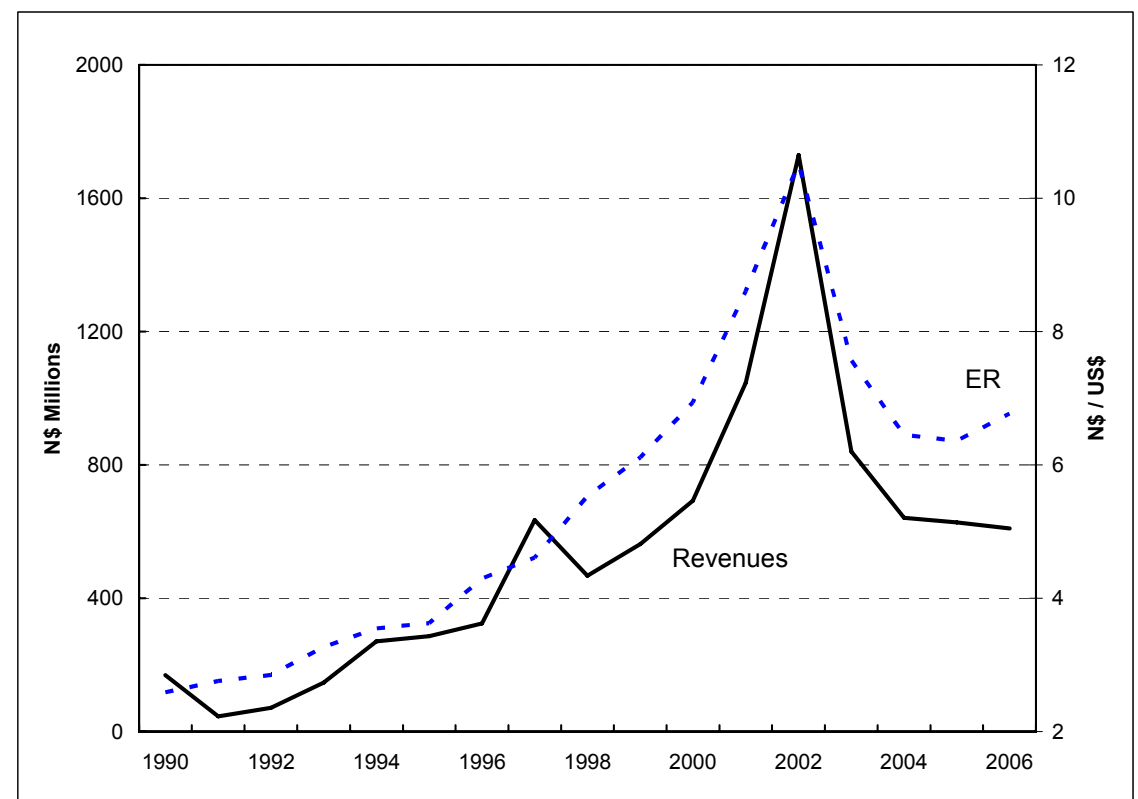

\section{Mineral sector volatility has been managed in some countries through}

stabilization funds. Of 31 oil producing countries examined, the IMF found that 21 had established stabilization funds. Under these arrangements, a stream of mineral revenues, based on a reference export price, is contributed to the general revenue pool to fund government spending. If export prices exceed the reference price, generating a surplus in mineral revenues, this surplus is dedicated to a stabilization fund. Accumulated balances in the fund are available to sustain spending in the event of a shortfall in export prices and/or mineral revenues.

115. Stabilization funds do not guarantee fiscal smoothing, however. The discipline that they provide can be circumvented if governments borrow during periods of high mineral export prices to boost spending. ${ }^{17}$ Given this, sound fiscal management requires that expenditures be insulated from swings in mineral revenues, being based (ideally) on a medium-term evaluation of resource and fiscal sustainability.

\section{Instead of using a stabilization fund, Namibia strives to smooth spending and} achieve fiscal discipline directly. While there are no specific provisions to increase public savings during periods of peak mineral revenue receipts, the government's fiscal goal of limiting public debt to 25 percent of GDP or less prevents borrowing against future mineral receipts. In addition, the use of a medium-term expenditure framework (MTEF) allows the budget to be developed in a multi-year setting, so that expenditures do not excessively reflect short-term revenues, including from the mineral sector.

\footnotetext{
${ }^{17}$ See The Role of Fiscal Institutions in Managing the Oil Revenue Boom. IMF Policy Paper, March 5, 2007.
} 


\section{In practice, mineral receipts do not appear to influence spending decisions.}

Indeed, from 1989 to 2006, increases in mineral revenues were associated, on average, with lower, not higher public spending, relative to GDP (Table IV.2). This likely reflects the role of the exchange rate. Currency depreciation boosts mineral incomes as well as overall GDP, both of which rise relative to incomes and expenditures in the non-mineral economy. Thus, currency depreciation boosts mineral incomes, and, to a lesser extent, strengthens the overall fiscal position. The limited relationship between mineral receipts and the fiscal position is evident from Figure IV.6.

Figure IV.6. Namibia: Revenues and Fiscal Impact, 1989/90-2005/06 (Percent of GDP)

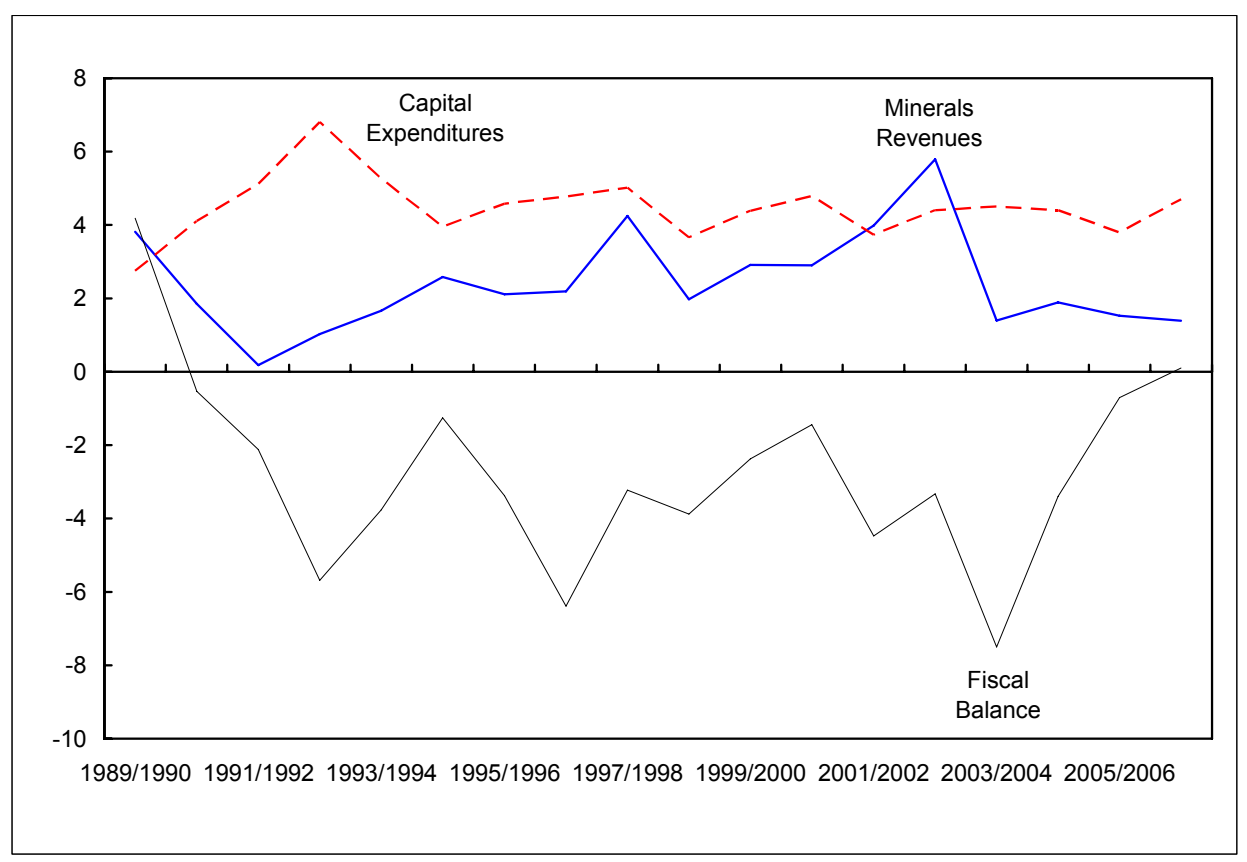

Table IV.2. Namibia: Short-Term Fiscal Pass-Through, 1990-2005

(All original data in percent of GDP)

\begin{tabular}{lccccc}
\hline $\begin{array}{l}\text { Correlation } \\
\text { with: }\end{array}$ & $\begin{array}{c}\text { Total } \\
\text { revenues }\end{array}$ & $\begin{array}{c}\text { Non-SACU } \\
\text { revenues }\end{array}$ & $\begin{array}{c}\text { Current } \\
\text { spending }\end{array}$ & $\begin{array}{c}\text { Capital } \\
\text { spending }\end{array}$ & $\begin{array}{c}\text { Fiscal } \\
\text { balance }\end{array}$ \\
\hline $\begin{array}{l}\text { Mineral } \\
\text { revenues }\end{array}$ & 0.05 & 0.58 & 0.00 & -0.37 & 0.15 \\
SACU revenues & 0.66 & -0.41 & 0.39 & 0.29 & 0.07 \\
\hline
\end{tabular}

Source: Fund staff estimates

118. Mineral revenues are important but not essential to government spending. Since 1990, mineral revenues have averaged just 21/2 percent of GDP (Figure IV.7), compared to total public expenditures of 32 percent of GDP. Thus, revenue administration and public expenditure management are more critical to fiscal stability than the mineral revenue regime. 
Figure IV.7. Namibia: Mineral and Other Revenue Contributions, 1991/92-2005/06 (Percent of GDP)

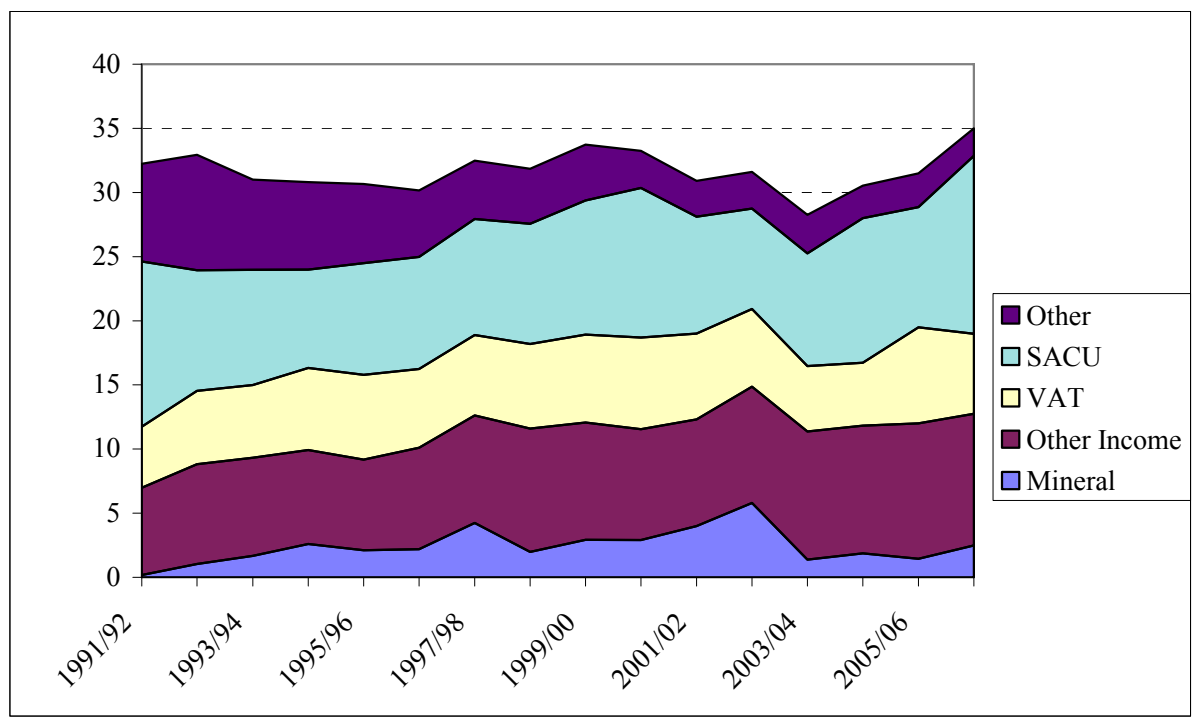

119. In practice, Namibia's budget is more at risk from volatility in SACU revenues. These averaged more than 9 percent of GDP over the past ten years compared with 2-3 percent of GDP for mineral revenues. Moreover, they have been more closely correlated with government expenditures, with a one percentage point of GDP increase in SACU revenues correlated with a 0.68 percentage point of GDP increase in total spending (Table IV.2). This underlines the importance of caution when projecting SACU revenues and the expenditures which they would finance.

\section{Ensuring long-term fiscal sustainability}

\section{Namibia's non-petroleum mineral extraction is projected to remain robust at} least through 2020, supplemented thereafter by natural gas reserves. Namibia's diamond production is expected to continue at about $2 \frac{1}{4}$ million carats per year through the year 2010 and then decline gradually to about 1.9 million carats by the year 2020, when land-based resources are expected to be depleted. Marine-based diamonds are only beginning to be exploited and the long-term prospects are particularly uncertain at this stage. With stable international prices, diamond exports are expected to contribute 12-13 percent of real GDP in the medium-term, but gradually decline to about 11 percent of GDP by 2020 (see Appendix). ${ }^{18}$

\footnotetext{
${ }^{18}$ Prospects for the smaller part of mineral production in the non-diamond sector are more difficult to assess. Uranium production at the Rössing mine was initially expected to last until 2009 but due to high international prices, the life of the mine has been extended to 2021, and a large number of new uranium investments are in train. The Skorpion zinc mine is expected to remain in production for a period of 15 years, to 2020 . While Namibia does not currently produce oil or gas, the development of the Kudu gas fields beginning in 2010-12 may offset declining production of other minerals.
} 
121. The permanent annuity value of Namibia's diamonds to the budget is smallabout one-half of one percent of GDP per annum. Since the projected fiscal revenues of about $1-1 \frac{1}{2}$ percent of GDP from the diamond sector over the next decade (see Appendix) exceed this annuity value, a case can be made for saving the difference (equivalent to 1 percent of GDP or less). However, this "optimal" saving is small, and does not merit a separate mineral fund. Indeed, the projected public saving rate of more than 5 percent of GDP (Figure II.3) adequately encompasses this specific savings goal. (In practice, under government proposals, these savings will finance domestic infrastructures).

\section{E. The Macroeconomic Impact of Resource Extraction}

\section{Several authors have found that countries endowed with plentiful natural} resources experience slower growth. Sachs and Warner (1995) find that in a sample of 97 developing countries for the period 1970 to 1989 , those with a high value of resource based exports to GDP experience lower subsequent growth. Collier (2007) studies the experiences of commodity exporting countries from 1960 to 2004 . He finds that booms in the prices of nonagricultural natural resources have a negative effect on growth, with the level of real GDP lowered by 26 percent after 25 years. Economists have proposed several possible causes for this negative impact of natural resource endowments on growth, including Dutch disease, increased volatility of growth, increased debt, corruption, and large economic rents. These risks are reviewed below.

\section{Dutch disease}

123. Dutch disease is a lesser concern for Namibia than other raw material exporters for several reasons. First, mineral exports have been a relatively moderate share of GDP (20-25 percent), with a general downward trend (Figure IV.8). Moreover, this overstates the domestic expenditures by the mineral sector. Much of the capital equipment is imported, and labor costs are low (mining accounts for about 2 percent of national employment). At the same time, fiscal revenues from the mining sector have averaged just 2-3 percent of GDP. To this extent, the domestic pricing pressures from the mineral sector are relatively modest. Equally, with high unemployment, wage pressures are unlikely to be large, except for certain pools of skilled personnel. 
Figure IV.8. Namibia: Mineral Exports as a Share of GDP, 1990-2006 (Percent)

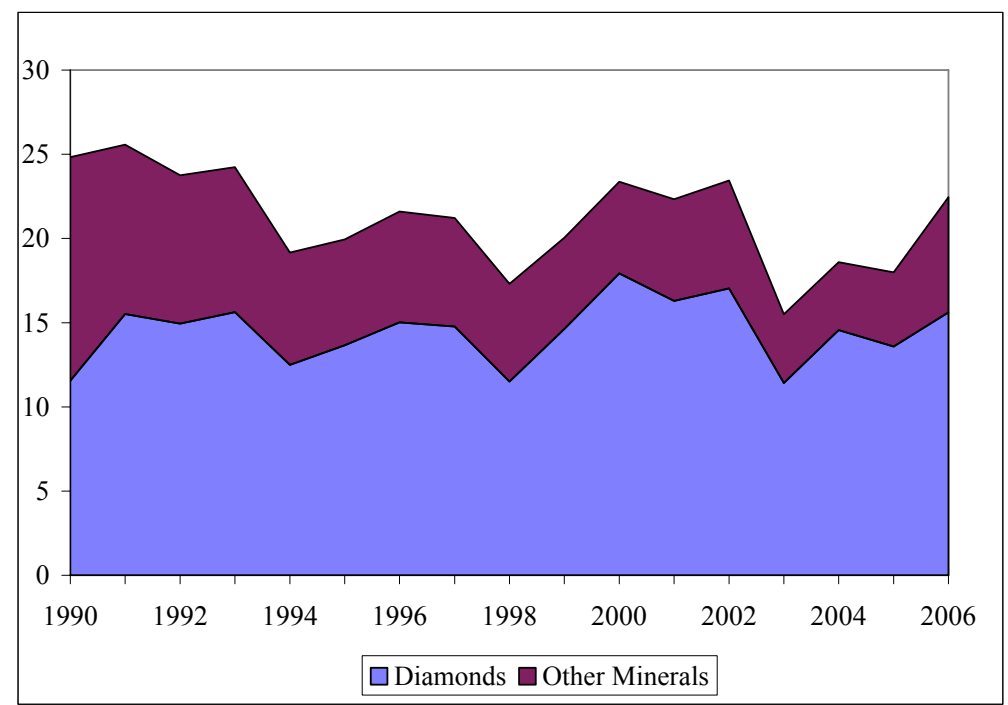

\section{Growth volatility issues}

\section{Mineral sector volatility has not been an excessive concern for Namibia. Its} mineral sector is smaller than in many resource-rich countries, and the volatility in export and fiscal proceeds is correspondingly more modest. As noted above, the pass-through from mineral incomes to spending has been limited, damping any tendency for stop-go spending patterns in the budget. Thus, while the contributions of the diamond sector to overall GDP growth has been unpredictable, this has not prevented sustained, albeit modest growth in the non-diamond economy (Figure IV.9).

Figure IV.9. Namibia: Contributions to Real GDP Growth, 1991-2006 (Percent)

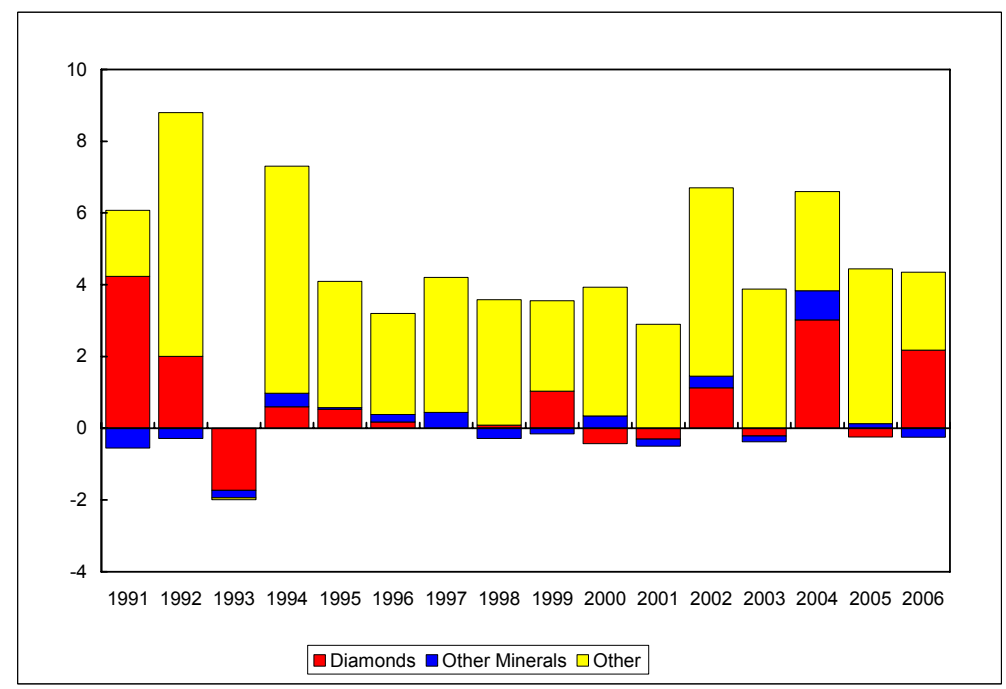




\section{Government borrowing}

125. A third possible cause of the negative impact of natural resource endowments on growth is through government debt. Since natural resources provide a revenue stream in foreign currency, countries with large natural resource endowments may find it easier to borrow abroad and fall into a debt trap. In Namibia's case, the government aims at keeping public debt to GDP at or below 25 percent. While public debt to GDP has risen as high as 34 percent, government debt is still much lower than in many other African countries. In addition, external debt of the government has also been low, measuring only $53 / 4$ percent of GDP as of June 2007.

\section{Overall assessment}

126. In conclusion, while mineral production comprises a large portion of value added in the economy, it has so far had minimal impact on the level and volatility of growth. Namibia should be relatively immune from Dutch disease effects. In addition, the Namibian government has been relatively prudent in borrowing, establishing a goal that public debt should be no more than 25 percent of GDP. For these reasons, mineral production has had a relatively benign impact on Namibia's growth.

\section{F. Conclusion}

127. Namibia's non-renewable natural resource sector is a significant contributor to Namibia's economy, comprising 21 percent of GDP, 57 percent of exports, and $7 \frac{1}{2}$ percent of government revenues. Namibia's regime for mining and processing is in line with international best practice and the IMF has recommended only minor changes. Namibia does appear to have suffered from a resource curse and public institutions rank well in international comparisons. As to shocks, most volatility arises from changes to diamond output and the exchange rate. Since mineral revenues are relatively small compared to GDP (only 1-2 percent) there does not appear to be an argument to create a stabilization/savings fund. In addition, Namibia is able to achieve its fiscal targets through an appropriate set of fiscal rules such as the requirement that public debt remain at or below 25 percent of GDP. As far as macroeconomic impact, Namibia's mineral income has remained relatively stable as a percent of GDP and exports and contributed about one percent of GDP on average to growth since independence. Thus, economic management of the impact of mineral income has not been difficult.

\section{Looking forward, it will be important for Namibia to continue manage its} mineral resources wisely. In this regard, the government may want to examine ways to improve the tax regime for mining. This could help to deal with projected decline in customs union revenues over the medium-term. The government may also want to consider ways to use its mineral wealth to diversify the economy to deal with economic shocks and the eventual exhaustion of its mineral resources. 


\section{REFERENCES}

Collier, Paul and Benedikt Goderis. Commodity Prices, Growth, and the Natural Resource Curse: Reconciling a Conundrum. Centre for the Study of African Economies Working Paper 2007-15. University of Oxford. August 2007.

Collier, Paul. Managing Commodity Booms: Lessons of International Experience. Centre for the Study of African Economies, Department of Economics, Oxford University. January 2007.

Insight Magazine. Mining in Namibia: Past Performance and Future Prospects. August 2006.

International Monetary Fund, Africa Regional Outlook, April 2007.

Sachs, Jeffrey D. and Andrew M. Warner. Natural Resource Abundance and Economic Growth. NBER Working Paper 5398, 1995. 


\section{APPENDIX}

\section{Assessment of Long-Run Diamond Income and the Permanent Income Hypothesis}

To maintain long-run fiscal sustainability some countries have instituted mineral stabilization/savings funds with strict rules on how such funds can be spent. The idea is to save a portion of mineral revenues in order to create a sustainable source of long-run income for the government. A savings fund can cushion the impact of fluctuations in other sources of revenues. This appendix examines the rationale for such a fund in Namibia. The general conclusion is that a savings fund in Namibia would generate only small amounts of income relative to GDP and thus would probably not be needed.

Various assessments of Namibia's diamond resources indicate that they can be exploited at close to current levels out to 2020. In 2006, Namdeb's total diamond output (more than 90 of Namibia's total) was 2.2 million carats. Namdeb has stated that it believes it can achieve annual output at or above 2 million carats out to 2010, and this exercise assumes production of 2.3 million carats out to 2012. The outlook beyond 2012 is uncertain and this appendix examines three scenarios. The baseline scenario assumes output falls gradually to 1.9 million carats in 2020 at which point diamond production begins to decline as resources are depleted. Diamonds are exhausted by 2035 . The optimistic scenario assumes marine mining of diamonds is more successful, producing a higher level of output, and diamond resources are not exhausted until 2040. In the pessimistic scenario output declines to zero by 2030.

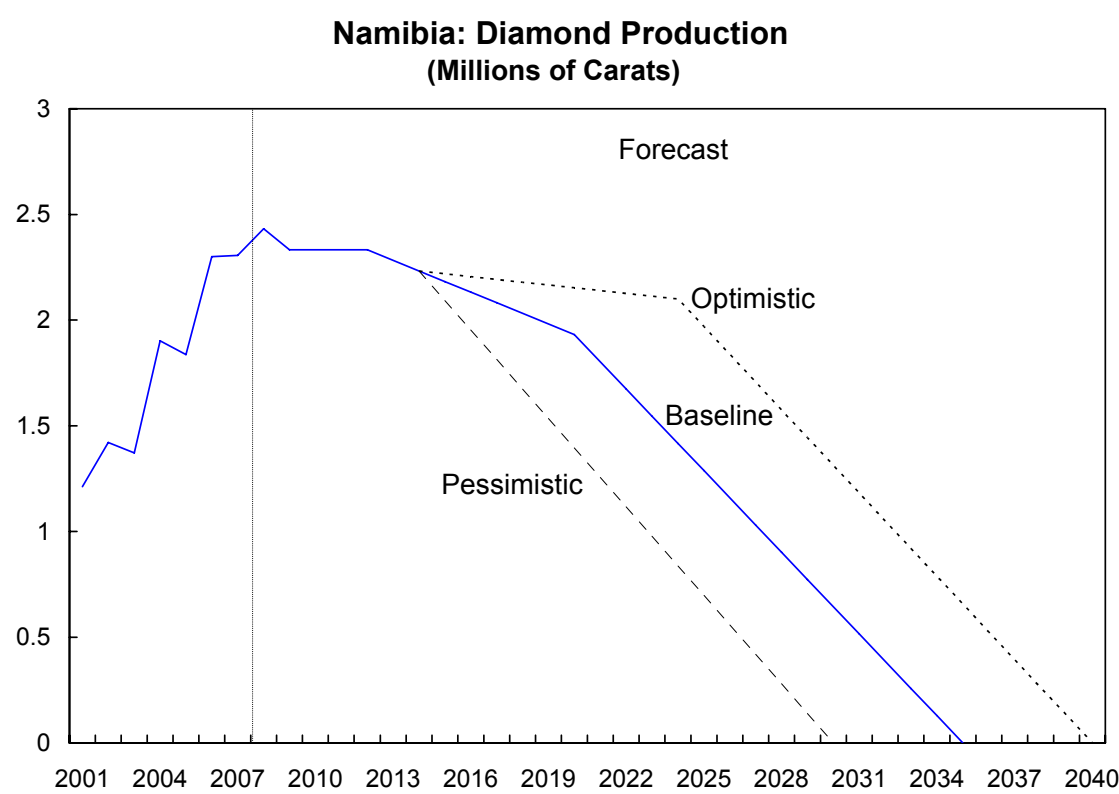

Under the permanent income hypothesis of consumption, individuals attempt to smooth consumption in the face of income shocks. They do this by saving income in good years to pay for consumption in bad years. 
Formally, individuals maximize a lifetime utility function:

$U=\sum_{j=0}^{\infty} \beta^{j} u\left(C_{t+j}\right)$

Subject to the budget constraint:

$\sum_{j=0}^{\infty} \frac{C_{t+j}}{(1+i)^{j}} \leq W_{0}+\sum_{j=1}^{\infty} \frac{Y_{t}}{(1+i)^{j}}$

Where:

$C_{t}=$ period consumption

$\mathrm{Y}_{\mathrm{t}}=$ period income

$\mathrm{W}_{0}=$ initial wealth

Solving this equation gives the first order condition:

$u^{\prime}\left(C_{t}\right)=\beta(1+r) u^{\prime}\left(C_{t}\right)$

With $\beta(1+r)=1$ or with quadratic utility consumption is constant over time, $C_{t}=C_{t+j}, \forall \mathrm{j}$.

To apply this to the case of Namibia's mineral wealth we make a number of simplifying assumptions:

1. Initial wealth is zero, $\mathrm{W}_{0}=0$.

2. Individuals want consumption to rise over time at the rate of GDP growth, g, so that $C_{t+1}=\mathrm{C}_{\mathrm{t}}(1+g)$.

3. The government maximizes utility on behalf of individuals so that $C_{t}=\mathrm{G}_{\mathrm{t}}$.

4. The government only smooths consumption from mineral income. Moreover, because mineral resources will eventually be depleted, income stops after year T.

Inserting these assumptions into the budget constraint gives:

$\sum_{j=0}^{\infty} \frac{G_{t+j}}{(1+i)^{j}}=\mathrm{NPV}_{\text {minerals }}$

$G_{t} \sum \frac{(1+g)^{j}}{(1+i)^{j}}=\frac{1}{(i-g)} G_{t}=\mathrm{NPV}_{\text {minerals }}$

where $\mathrm{NPV}_{\text {minerals }}=\sum_{\mathrm{j}=0}^{\mathrm{T}} \mathrm{Y}_{\mathrm{t}+\mathrm{j}}$ 
or

$G_{t+j}=(i-g) \mathrm{NPV}_{\text {minerals }}(1+g)^{j} \quad \forall j \geq 0$

Thus the mineral wealth, NPV minerals, can be converted into an annuity of (i-g) x NPV minerals in year 0 , that grows at the same rate as GDP.

Projections were made based on the following assumptions, with 2006 corresponding to year zero:

\begin{tabular}{lc}
\hline \multicolumn{1}{c}{ Variable } & Value \\
\hline Nominal interest, i & $12.0 \%$ \\
Real GDP growth & $5.0 \%$ \\
Inflation & $5.5 \%$ \\
Nominal GDP growth, g & $10.8 \%$ \\
\hline
\end{tabular}

In the baseline forecast, the annuity value of Namibia's diamond tax revenues is only 0.40 percent of GDP per year. Because the result varies with the interest rate assumption, a sensitivity analysis was carried out. If $(\mathrm{i}-\mathrm{g})$ rises from its historical average of 1.2 percent to 2.0 percent, the annuity value rises to 0.54 percent of GDP per annum.

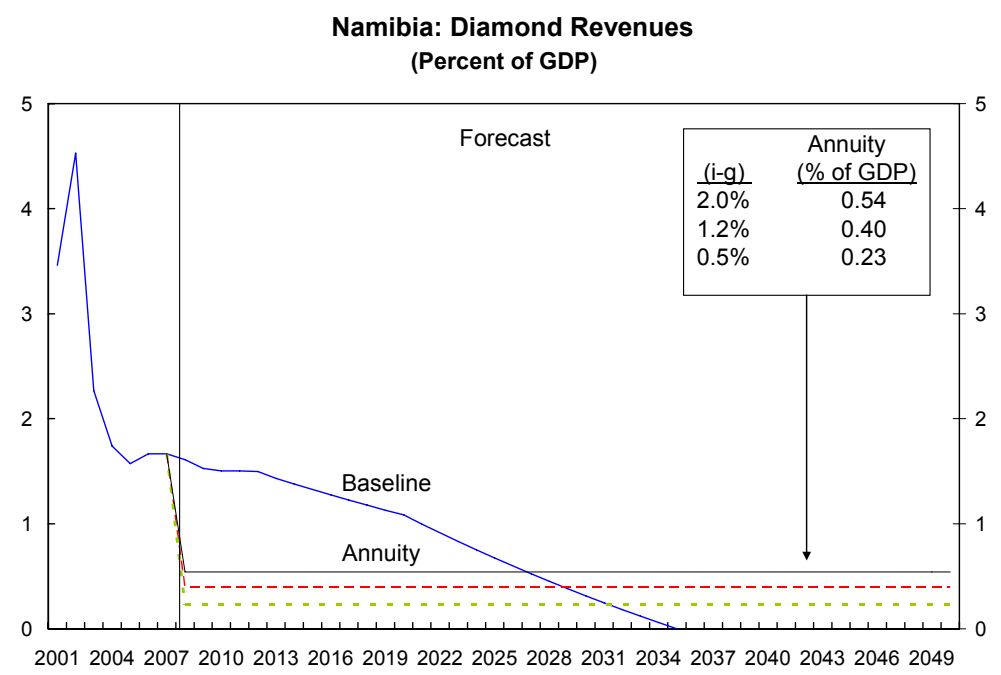

Under the optimistic scenario with ( $\mathrm{i}-\mathrm{g})$ at 1.2 percent the annuity value of Namibia's diamond tax revenues is 0.48 percent of GDP. 


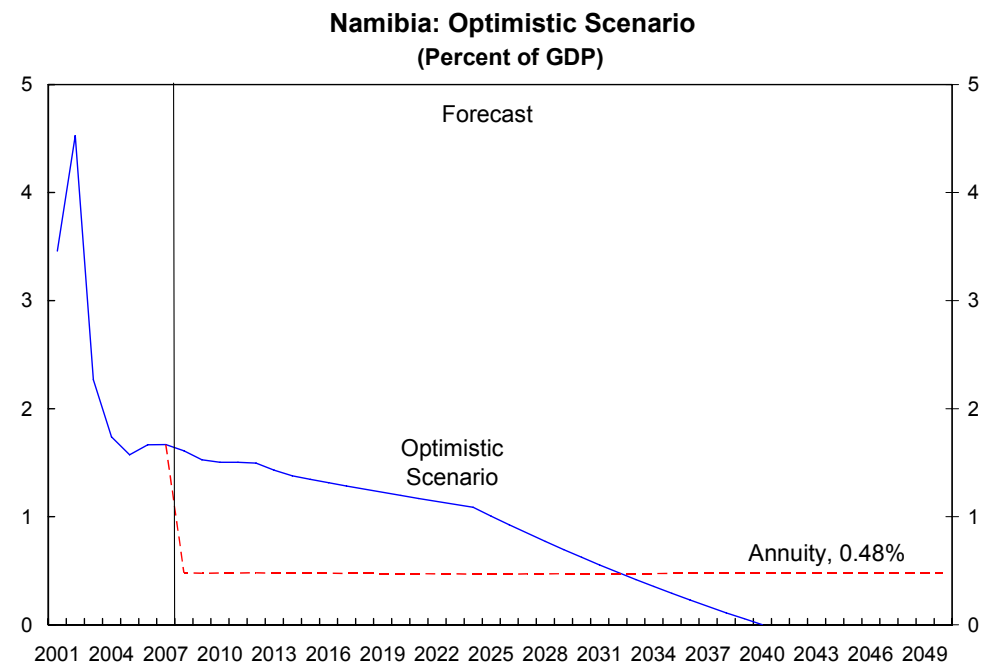

Under the pessimistic scenario the annuity value falls to 0.33 percent of GDP.

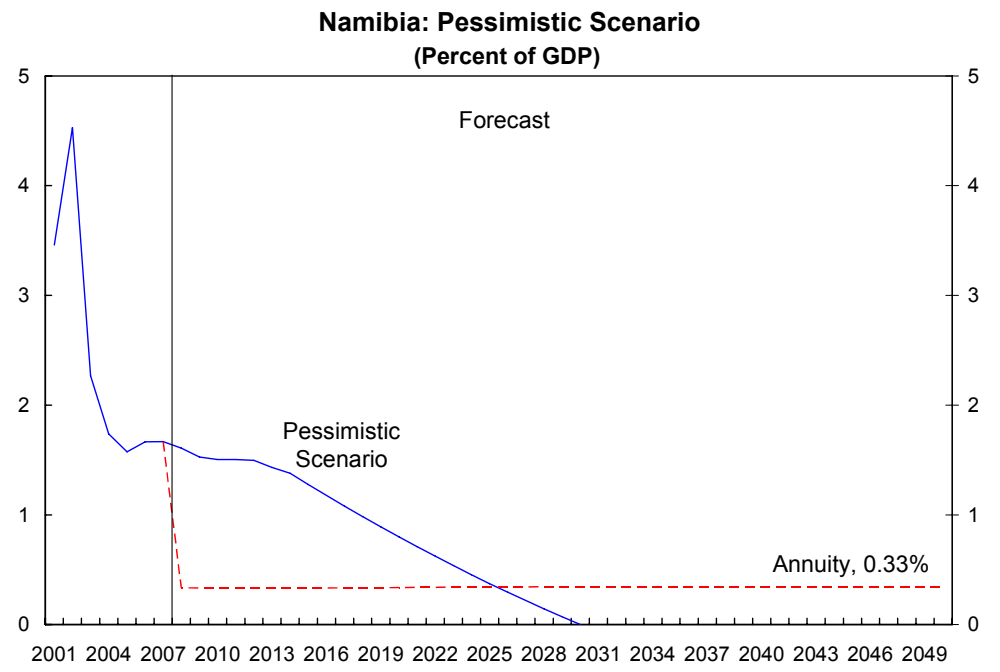

In conclusion, the annuity value of Namibia's diamond tax revenues is relatively small, measuring 0.6 percent of GDP or less per annum, under all scenarios. This compares with recent tax revenues from the diamond sector of $1 \frac{1}{2}-3 \frac{1}{2}$ percent of GDP. By implication, the government should save the difference between the actual and the annuity value of revenues to smooth revenues, amounting to one percent or more of GDP per annum. This is relatively modest and broadly in line with actual average public saving of $1 \frac{1}{2}$ percent of GDP during 1 1 $\frac{1}{2}$ percent of GDP during 1990-2005 (see Chapter 1). Given the modest size of the implied savings, there appears to be little justification for separating diamond revenues from the general budget for a savings fund. 


\section{The Challenges OF ReduCing Unemployment ${ }^{19}$}

\section{A. Introduction}

129. High and persistent unemployment is one of the most pressing issues facing Namibia. Despite annual GDP growth of 4.6 percent during 2000 to 2005, the unemployment rate has risen from 34.5 percent in 2000 to 36.7 percent in $2004,{ }^{20}$ which is high by broader African standards.

\section{Employment growth has been inhibited by generally low skill levels, lack of} diversification of the economy, and labor market inflexibilities. At independence in 1990, Namibia inherited a poor education system that did not prepare students well for the work place. Job opportunities have also been restricted by a heavy dependence on the capitalintensive mining and mineral processing. At the same time, labor market impediments have deterred job creation outside the mining sector.

131. Faster growth in low-skill job opportunities and more flexible labor market institutions would help tackle unemployment in the short run. While improvements in education and training are required over the long run, near-term job creation may require lower-skill, entry-level positions in manufacturing, tourism, and other service activities. More competitive labor costs and flexible labor market institutions would help encourage investments in these sectors.

\section{B. Unemployment Overview}

132. Weak job growth has resulted in rising unemployment. Employment growth of less than 1 percent per annum during 1992-2004 contrasted with annual labor force growth of about 3 percent, resulting in an increase in unemployment from 19 percent in 1992 to 37 percent in 2004, comparable to Lesotho and South Africa, but well above a number of other African peers (Table V.1).

\footnotetext{
${ }^{19}$ Prepared by Chuling Chen (AFR).

${ }^{20}$ Broad definition. Data from Namibia Labour Force Survey 2000, 2004.
} 
Figure V.1. Namibia: GDP Growth, Employment, and the Labor Force
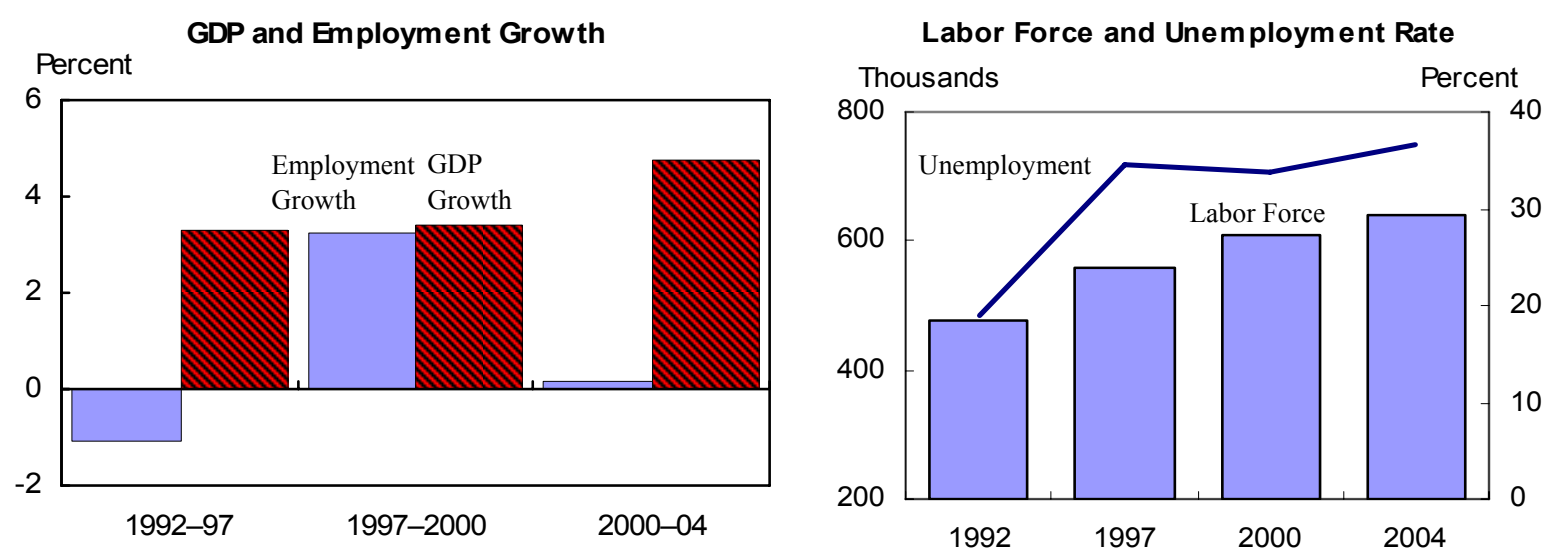

Table V.1. Labor Force Participation and Unemployment

\begin{tabular}{lccc}
\hline Country & Year & Labor Participation & Unemployment Rate 1/ \\
\hline Namibia & 1997 & 53.5 & 19.5 \\
Namibia & 2000 & 54.0 & 20.2 \\
Namibia & 2004 & 47.9 & 21.9 \\
& & & \\
Botswana & 2006 & 57.2 & 15.3 \\
Cameroon & 2001 & 68.9 & 7.5 \\
Egypt & 2005 & 49.3 & 11.2 \\
Lesotho & 1999 & 64.0 & 27.3 \\
Mauritius & 2006 & 65.5 & 9.1 \\
South Africa & 2006 & 65.1 & 25.5 \\
Tunisia & 2005 & 54.9 & 14.2 \\
\hline
\end{tabular}

Sources: Namibia Labour Force Survey; International Labor Organization; and World Bank Development Indicators

$1 /$ Narrow definition, excluding those not looking for work

133. Unemployment varies significantly by region, gender, age, and education level.

On a broad definition, including those seeking work, unemployment ranges regionally from a low of 19 percent to a high of 65 percent. On the same basis, rural unemployment is higher than urban (45 percent, compared to 29 percent), and women are more likely to be unemployed than men (43 percent, compared to 30 percent). Unemployment is particularly high among the young, reaching 57 percent in the 20-24 age group. Unemployment is also higher for those with lower education levels: those with less than secondary education face unemployment rates of over 30 percent (Figure V.2). 
Figure V.2. Namibia: Unemployment Characteristics
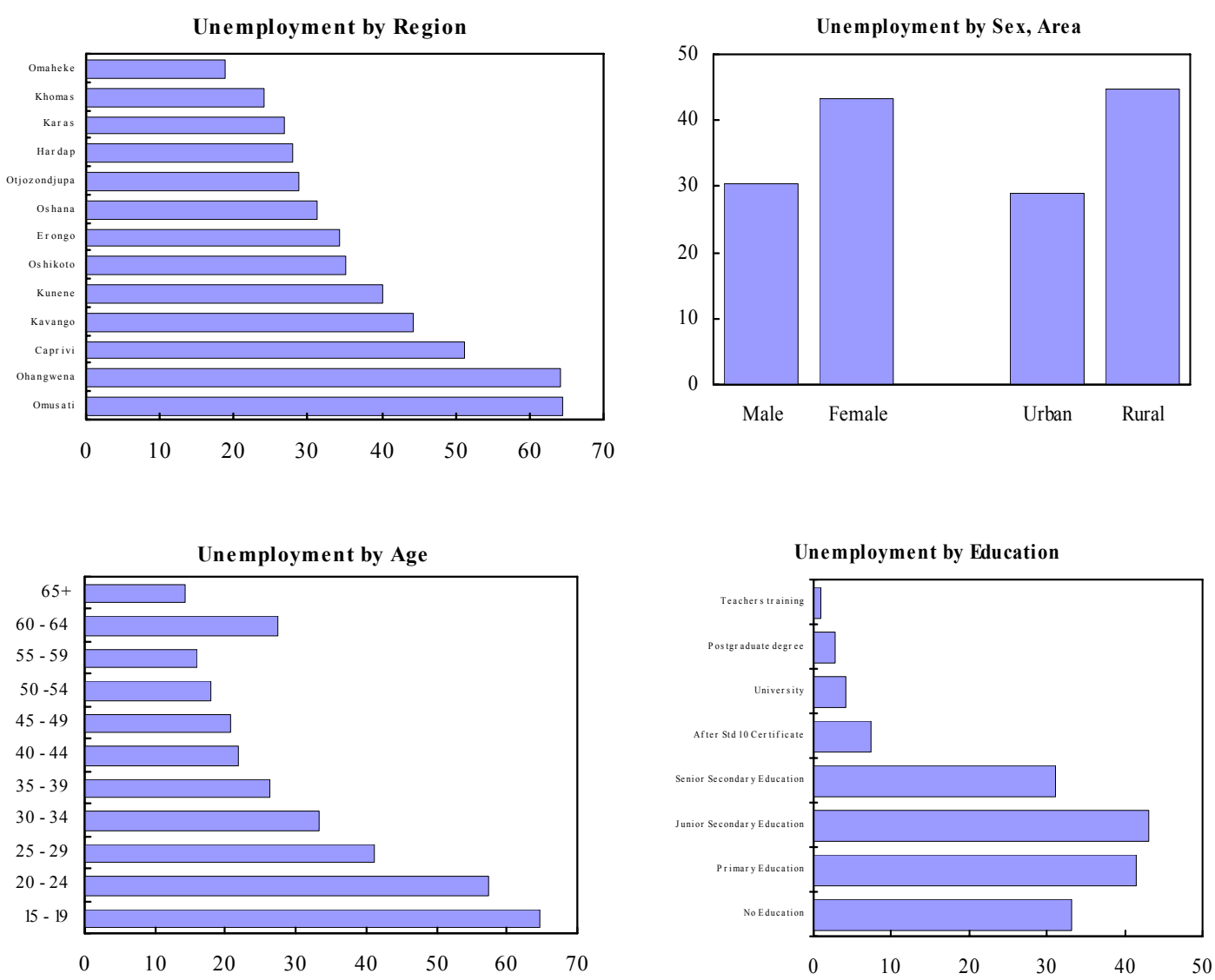

134. Discouraged workers and underemployment are common. Almost half of the unemployed are not seeking jobs, while 56 percent of those actively looking for employment have been unemployed for more than 2 years. At the same time, nearly one third of employed workers experience some degree of underemployment and are interested in additional work.

Figure V.3. Namibia: Discouraged Workers and Under Employment
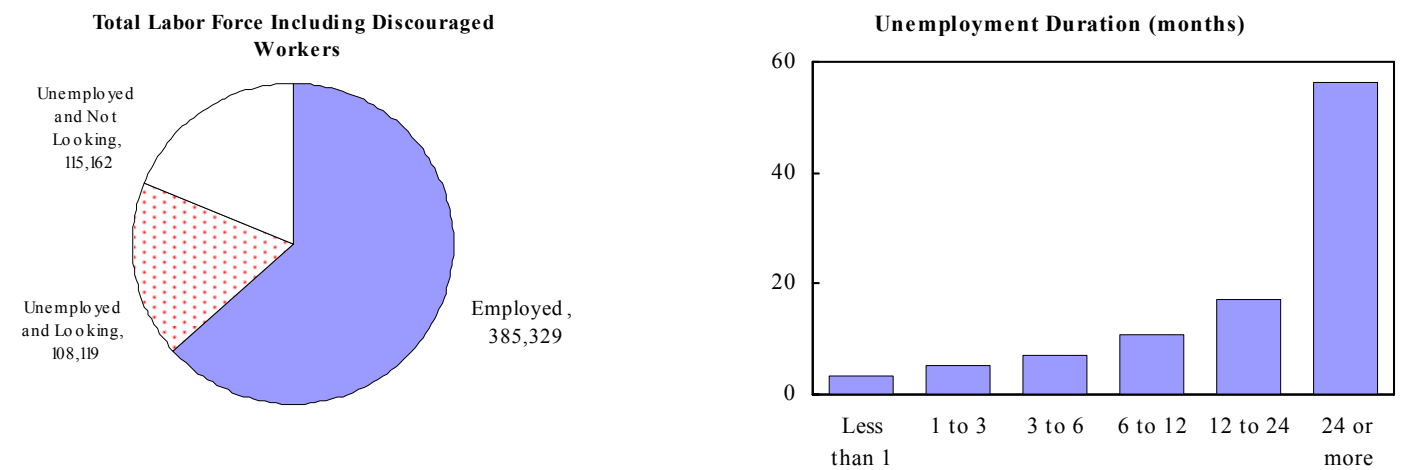


\section{Contributions to High Unemployment}

\section{Low skills}

135. Lack of skills and low educational attainment contribute to high unemployment. Compared to workers with no education, those with senior secondary education (beyond grade 10) face a 60 to 80 percent higher probability of being employed (Figure V.4). Perhaps surprisingly, primary and junior secondary education does not appear to strengthen job prospects. This finding is consistent with a recent World Bank (2005) study, which finds a negative return on primary education in raising employees' wage levels. The apparently weak impact of education through the junior secondary level is a concern, given that only 20 percent of the working age population is educated beyond this point.

Figure V.4. Namibia: Education and Employment Probability
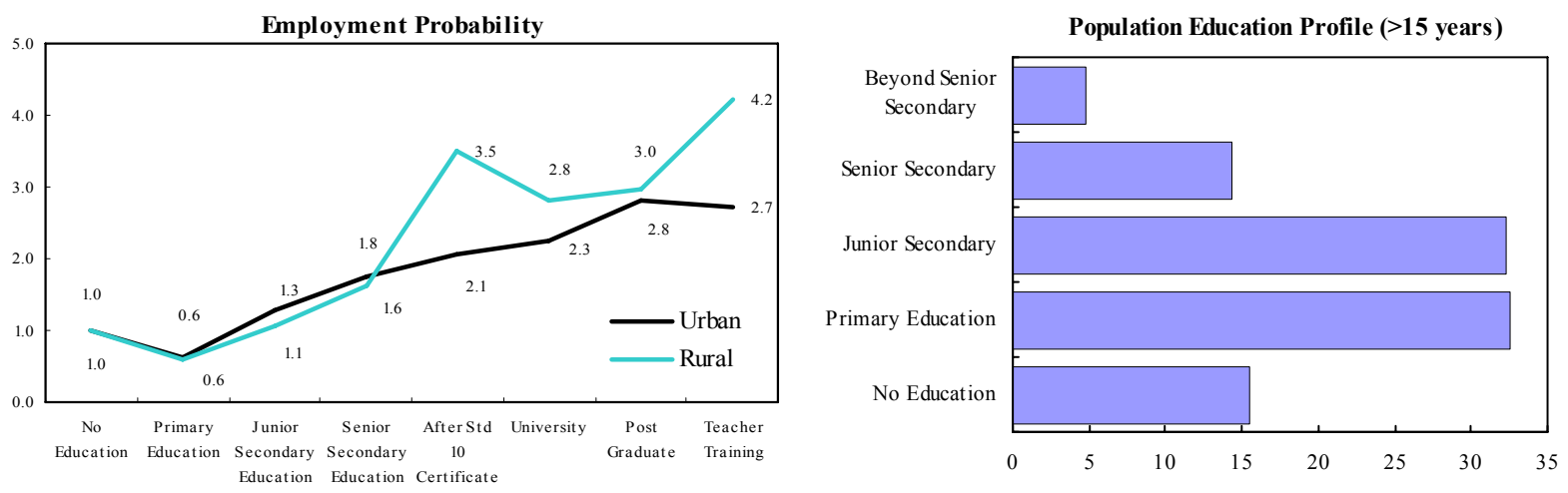

136. Scarcity of skilled workers results in high wage premia. Skilled workers earn about 5 times the wage of the unskilled, and for professional and managerial workers, wages are about 10 times higher. These skill premia appear large, by international standards (Table V.2).

Table V.2. Wage Differentials

Namibia Wage Differential 2001-07

\begin{tabular}{lcc}
\hline & $2001-04$ & $2005-07$ \\
\hline Unskilled & 1 & 1 \\
Semi-skilled & 3 & 3 \\
Skilled & 5 & 5 \\
Highly skilled, professional & 10 & 9 \\
Highly skilled, managerial & 17 & 12 \\
\hline
\end{tabular}

Source: Jobs Unlimited Salary Survey (2001-07)
Wage Differential in Selected Countries

\begin{tabular}{lcc}
\hline & Differential & \\
\hline Namibia & 5 & $1 /$ \\
Latin America & 4.3 & $2 /$ \\
East Asia & 3.4 & $2 /$ \\
US & 1.8 & $3 /$ \\
\hline
\end{tabular}

\footnotetext{
1/ Median wage of skilled to unskilled, staff estimate 2/ 90th to 10th percentile of wage for manufacturing workers in 1995, Avalos and Savvides (2003)

3 / Weighted average wage of college graduate to high school diploma in the mid 90s, Murphy and Welch (2002)
} 


\section{Economic structure}

137. Structural change has been biased against those with lower skills. Although the primary and secondary sectors offer proportionally more low-skill jobs, employment in these sectors declined between 1997 to 2004 by 3.6 percent and 0.8 percent per annum, respectively. By contrast, jobs in the service sector, which tend to be more high-skill, expanded by 1.7 percent per annum (Figure V.5). The bias of structural change toward high-skill jobs has also been noted for the South African labor market by Rodrik (2006). As in Namibia, this trend has been associated in South Africa with a stubbornly high unemployment for labor force participants with limited education and skills.

Figure V.5. Namibia: Annual Employment Growth by Industry, 1997-2004

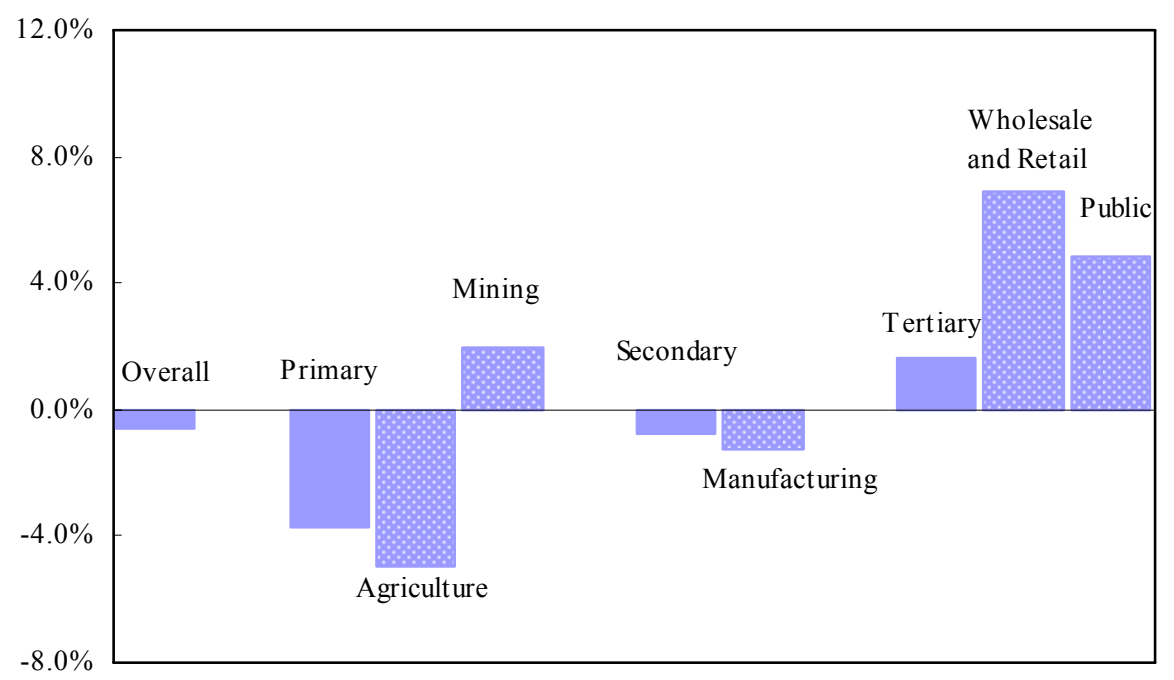

138. Mining and agriculture are not the answer. The mining sector is highly capital-intensive, and although employment has been rising, the base is very small, and unable to make a significant dent in unemployment. While the agricultural sector is a large employer of low-skill workers, value-added per worker is low (as well as incomes), and employment has been declining over the past decade. Moreover, with very low rainfall, Namibia is less well-suited to agricultural production than many economies, including a number of regional peers.

\section{Manufacturing is possibly an option, though the base is also small. The} manufacturing sector accounts for just 12-13 percent of employment and GDP. With a population of just two million, Namibia cannot build a manufacturing base without developing export markets. Progress on this front is also lagging, with manufacturing goods representing a smaller share of merchandise exports than for many peers (Table V.3). Beyond manufacturing, job options include construction and labor-intensive service sectors, including tourism. 
Table V.3. Manufacturing Share in GDP and Merchandise Exports

\begin{tabular}{lccc}
\hline Country & $\begin{array}{c}\text { Manufacturing, value } \\
\text { added (\% of GDP) }\end{array}$ & $\begin{array}{c}\text { Manufactures exports (\% of } \\
\text { merchandise exports) }\end{array}$ & \\
\hline Namibia & 13 & 41 & $2 /$ \\
Botswana & 4 & 86 & $2 /$ \\
Lesotho & 16 & n.a. & \\
South Africa & 19 & 57 & $3 /$ \\
Swaziland & 37 & 76 & \\
& & & \\
China & 33 & 92 & \\
Indonesia & 28 & 47 & \\
Korea & 28 & 91 & \\
Thailand & 35 & 77 & \\
\hline
\end{tabular}

Source: World Development Indicators

1/ Data for 2005, unless otherwise indicated.

2/ Data for 2003.

3/ Data for 2002.

\section{Labor costs}

140. Wage levels need to be competitive for labor-intensive export sectors in a global market. A recent World Bank report shows that the median monthly wage for a production worker in Namibia is higher than most other middle-income countries, except South Africa. While this is matched by relatively high productivity and capital intensity for existing companies, it could be an obstacle to the expansion of low-skill employment.

Figure V.6. Namibia: Median Monthly Wage for Production Workers

(U.S. dollars)

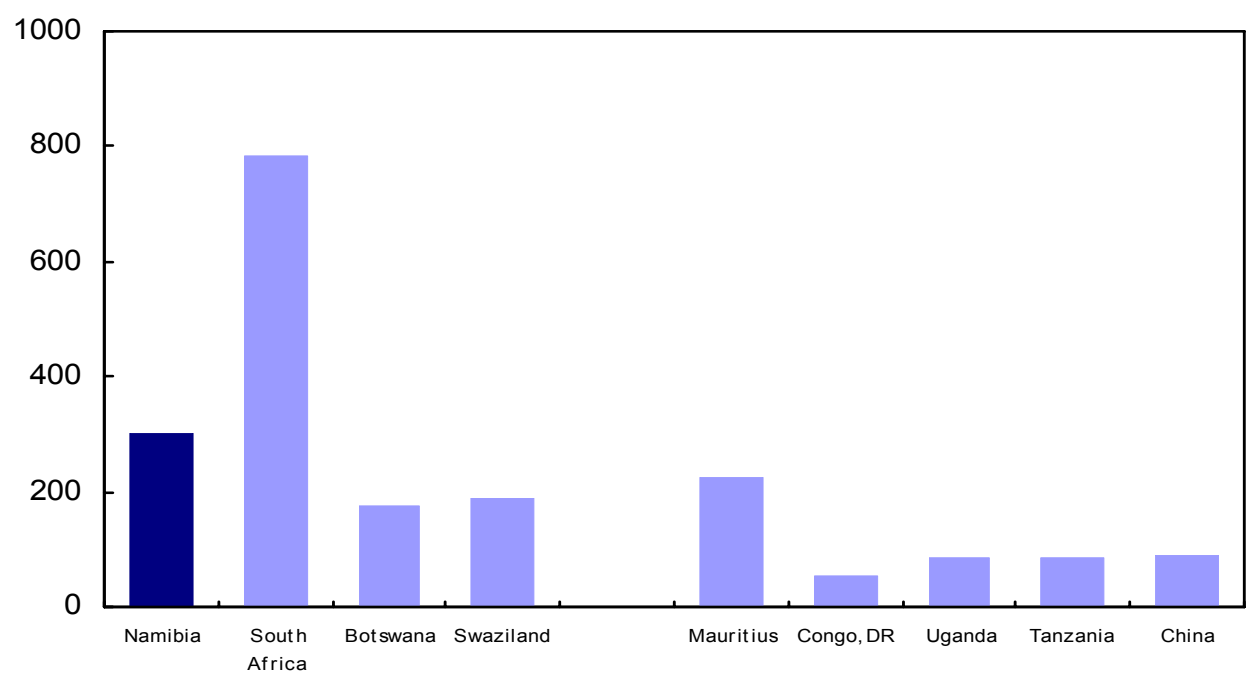


141. It is also important to minimize non-wage labor cost. Non-wage benefits constitute an important part of the overall labor cost in Namibia. The new Labor Act will increase minimum annual leave from 24 consecutive days (about 18 working days) to 24 working days; a further 5 days of compassionate leave will also be provided. ${ }^{21}$ These leave benefits are generous compared to many potential export competitors (Table V.4).

Table V.4. Statutory Leave Comparisons

\begin{tabular}{|c|c|c|c|}
\hline & $\begin{array}{c}\text { GDP Per Capita (PPP } \\
\text { basis, } 2006)\end{array}$ & $\begin{array}{l}\text { Unemployment } \\
\text { Rate, }(\%, 2006)\end{array}$ & $\begin{array}{l}\text { Paid Annual } \\
\text { Leave (days) }\end{array}$ \\
\hline \multicolumn{4}{|l|}{ Namibia } \\
\hline Current $1 /, 2 /$ & 8,600 & 22 & 18 \\
\hline New Labor Act $3 /$ & & & 29 \\
\hline South A frica & 13,000 & 26 & 15 \\
\hline Botswana $1 /$ & 15,700 & 24 & 15 \\
\hline Chile 4/ & 12,800 & 8 & 15 \\
\hline Malaysia 5/ & 12,000 & 3 & $8-16$ \\
\hline Thailand $6 /$ & 9,200 & 2 & 6 \\
\hline \multicolumn{4}{|c|}{ Sources: IM F database, and various sources for leave days } \\
\hline \multicolumn{4}{|c|}{$1 /$ Unemployment data for 2004} \\
\hline \multicolumn{4}{|c|}{$2 /$ Leave of 24 consecutive days. } \\
\hline \multicolumn{4}{|c|}{$3 /$ Leave of 24 working days plus 5 compassionate days. } \\
\hline \multicolumn{4}{|c|}{ 4/ Leave after 1 year's service. } \\
\hline \multicolumn{4}{|c|}{$5 /$ Leave rises from 8 days with up to 2 years' service to 16 days with 5 years or more with one employer. } \\
\hline
\end{tabular}

\section{Labor market institutions}

142. Rigidities in hiring and firing have been a deterrent to employment. The Namibian labor market is characterized by a high level of regulation. Private sector employers have complained about the difficulty in hiring part-time labor and expatriate workers. Lack of appropriate regulatory measures for temporary employment agencies have reduced contract jobs for unskilled and semi skilled workers. On the other hand, the burdensome and ineffective process of firing employees under the old Labor Act has made employers cautious in increasing employment levels (Box V.1).

\footnotetext{
${ }^{21}$ Employers will also be required under the new Labor Law to contribute to the benefits of workers on maternity leave, in contrast to the current regime, where payments are funded by the Social Security Commission.
} 


\section{Box V.1. Labor Dispute Resolution in Namibia}

Under the 1992 Act, labor disputes should be first resolved at the District Labor Courts, which handle complaints from either an employee or an employer on issues concerning labor laws, employment contracts or collective bargaining agreements. This results in an adversarial labor relations, with cases appealed to the higher labor courts and a high incidence of strikes and lockouts. The system has also been criticized for its low efficiency and difficulties in enforcing decisions resulted from its complicated structure. The new Labor Act seeks to improve the resolution process by using conciliation and arbitration instead of the District Labor Courts. Under the new Act, dispute will be referred to a Labor Commissioner, who appoints a conciliator and oversees the whole process of conciliation and arbitration. The conciliator is required to resolve the case within 30 days. If this fails, the parties can seek arbitration based on mutual agreement. In certain cases, the Labor Commissioner may require compulsory arbitration.

143. Strong union power is a feature of the Namibian labor market. Union membership is particularly high among government employees ( 57 percent), and unions appear to have been successful in raising the incomes of their members, with the 2003 Household Survey indicating that the mean hourly wage for a trade union member is about 45 percent higher than for a non-union member.

Figure V.7. Namibia: Unionization
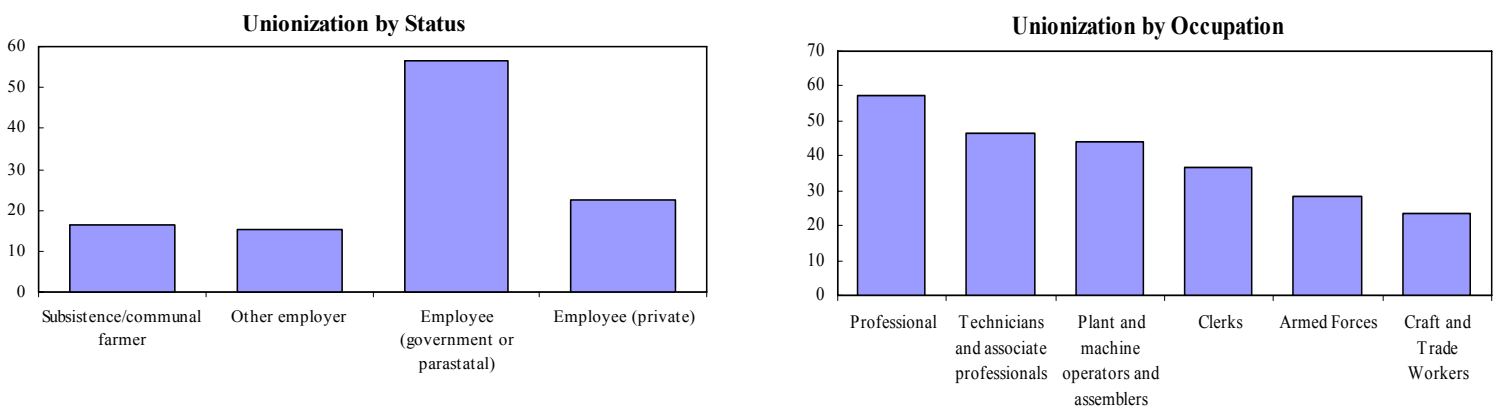

\section{Policies to Reduce Unemployment}

144. Over the longer term, strengthened education and training are a top priority for reducing unemployment. Efforts are needed to strengthen the quality of education through the junior secondary level, increase the proportion of students benefiting from higher secondary and tertiary education, and provide continuing education and training for those in the workforce. The government has initiated several programs in this area. A center-piece is the government's Education and Training Sector Improvement Program (ETSIP), which aims 
to improve the quality of general education, develop the use of information and communication technology, and expand vocational education and training. The program is to be implemented in three phases over 15 years, and funding was secured in May 2007 for the first phase from a coalition of development partners including the World Bank.

145. Policy measures are also needed to open up low skill employment. This will be important, given the time required to strengthen education and training in a broad-based manner. Given the limited prospects for job growth in mining and agriculture, policies should be focused on tackling obstacles to investment and growth of labor-intensive sectors such as manufacturing and construction.

146. More flexible labor market institutions could encourage labor demand. Relaxing the work permit regime to permit entry by foreign workers with critical skills could create rather than eliminate jobs for nationals by broadening the economic base. In addition, steps to eliminate undue restrictions on temporary work and worker dismissals could encourage employers to increase hiring. The latter is being addressed in the new Labor Act through a proposed expansion of conciliation and arbitration.

147. A more pro-business approach within the public sector would also be beneficial. It is important that public sector employees recognize the contribution of the private sector to job creation, and be helpful in minimizing any undue bureaucratic obstacles. This approach could be fostered through training provided to the civil service in the planned National Institute of Public Administration and Management, scheduled for opening in 2009. 


\section{REFERENCES}

Avalos, Antonio and Andreas Savvides, "On the Determinants of the Wage Differential in Latin America and East Asia: Openness, Technology Transfer and Labor Supply," LAEBA Working Paper No. 19, Inter-American Development Bank, October 2003.

Banerjee, Abhijit, Sebastian Galiani, Jin Levinsohn, and Ingrid Woolard, "Why Has Unemployment Risen in the New South Africa," NBER Working Paper No. 13167, June 2007.

Fox, Louise and Melissa Sekkel, "Work in Progress: Job Creation and the Quality of Growth in Africa," World Bank discussion paper, November 2006.

Marope, Mmantsetsa, "Namibia Human Capital and Knowledge Development for Economic Growth with Equity," World Bank Africa Region Human Development Working Paper Series 84, February 2005.

Murphy, Kevin and Finis Welch, "Wage Differentials in the 1990s: Is the Glass Half-full or Half-empty?", in The Causes and Consequences of Increasing Inequality, edited by Finis Welch, Chicago and London: University of Chicago Press, 2001, pp. 341-64.

Namibia Labor Force Survey 1997, 2000, 2004

Rodrik, Dani, “Understanding South Africa's Economic Puzzles," NBER Working Paper No. 12565, October 2006.

The Wage Bargaining Report 2004, 2005. 
Table 1. Namibia: GDP and Gross National Income (GNI) at Current Prices, 2001-06 1/

\begin{tabular}{|c|c|c|c|c|c|c|}
\hline & 2001 & 2002 & 2003 & 2004 & 2005 & 2006 \\
\hline & \multicolumn{6}{|c|}{ (In millions of Namibia dollars) } \\
\hline GDP at factor cost & 25,192 & 29,878 & 30,879 & 32,680 & 35,581 & 42,367 \\
\hline Compensation of employees & 10,616 & 12,012 & 13,051 & 13,903 & 14,973 & 16,473 \\
\hline Consumption of fixed capital & 3,561 & 4,073 & 5,303 & 5,913 & 6,585 & 6,300 \\
\hline Net operating surplus & 11,015 & 13,793 & 12,525 & 12,863 & 14,023 & 19,594 \\
\hline Taxes on production and imports & 3,158 & 3,582 & 3,104 & 4,030 & 4,367 & 4,847 \\
\hline Subsidies & -663 & -552 & -140 & -213 & -238 & -244 \\
\hline GDP at market prices & 27,686 & 32,908 & 33,842 & 36,476 & 39,711 & 46,971 \\
\hline Net primary incomes from rest of world & -10 & 356 & 1,732 & 539 & -715 & -489 \\
\hline Receivable from rest of world & 1,704 & 1,803 & 2,123 & 1,483 & 955 & 1,185 \\
\hline Payable to rest of world & $-1,714$ & $-1,447$ & -391 & -944 & $-1,670$ & $-1,674$ \\
\hline GNI at market prices & 27,677 & 33,264 & 35,574 & 37,035 & 38,996 & 46,482 \\
\hline Net current transfers & 2,985 & 2,894 & 3,467 & 4,304 & 4,262 & 6,465 \\
\hline Receivable from rest of world & 3,297 & 3,202 & 3,670 & 4,529 & 4,548 & 6,771 \\
\hline Payable to rest of world & -312 & -308 & -203 & -225 & -286 & -306 \\
\hline Gross national disposable income & 30,661 & 36,158 & 39,041 & 41,339 & 43,258 & 52,947 \\
\hline \multicolumn{7}{|l|}{ Memorandum items: } \\
\hline Real GNI at constant 1995 prices & 17,541 & 19,054 & 18,942 & 19,282 & 20,580 & 22,483 \\
\hline Percentage change & 5.6 & 8.6 & -0.6 & 1.8 & 6.7 & 9.2 \\
\hline Per capita GDP at current market prices & 14,346 & 16,789 & 17,041 & 18,154 & 19,550 & 22,934 \\
\hline Per capita GNI at current market prices & 15,887 & 18,447 & 19,658 & 20,574 & 21,296 & 25,852 \\
\hline
\end{tabular}

Source: Central Bureau of Statistics and IMF staff estimates.

1/ Columns may not sum due to rounding error. 
Table 2. Namibia: GDP by Industrial Origin at Current Prices, 2001-06 1/

\begin{tabular}{|c|c|c|c|c|c|c|}
\hline & 2001 & 2002 & 2003 & 2004 & 2005 & 2006 \\
\hline & \multicolumn{6}{|c|}{ (In millions of Namibia dollars) } \\
\hline GDP at basic prices & 24,916 & 29,747 & 31,187 & 32,930 & 35,798 & 42,698 \\
\hline Agriculture & 1,137 & 1,687 & 1,814 & 1,873 & 2,398 & 2,909 \\
\hline Commercial agriculture & 711 & 1,309 & 1,353 & 1,294 & 1,681 & 1,945 \\
\hline Subsistence agriculture & 425 & 378 & 461 & 579 & 717 & 963 \\
\hline Fishing & 1,445 & 1,608 & 1,757 & 1,547 & 1,916 & 1,958 \\
\hline Mining and quarrying & 3,663 & 4,565 & 2,975 & 3,489 & 3,391 & 5,518 \\
\hline Diamond mining & 2,854 & 3,427 & 2,630 & 3,048 & 2,782 & 4,054 \\
\hline Other mining and quarrying & 809 & 1,138 & 345 & 441 & 609 & 1,463 \\
\hline Subtotal, primary industries & 6,244 & 7,859 & 6,546 & 6,909 & 7,704 & 10,385 \\
\hline Manufacturing & 2,604 & 3,305 & 3,870 & 4,001 & 4,055 & 5,628 \\
\hline Meat processing & 142 & 143 & 139 & 126 & 121 & 81 \\
\hline Fish processing & 494 & 703 & 876 & 750 & 466 & 608 \\
\hline Food products and beverages & 1,215 & 1,515 & 1,650 & 1,690 & 1,772 & 1,979 \\
\hline Other manufacturing & 753 & 944 & 1,205 & 1,434 & 1,696 & 2,959 \\
\hline Electricity and water & 620 & 854 & 1,003 & 1,197 & 1,344 & 1,250 \\
\hline Construction & 789 & 725 & 1,029 & 1,100 & 1,247 & 1,743 \\
\hline Subtotal, secondary industries & 4,013 & 4,884 & 5,901 & 6,298 & 6,646 & 8,621 \\
\hline Wholesale and retail trade and repairs & 3,004 & 3,428 & 3,987 & 3,985 & 4,235 & 5,191 \\
\hline Hotels and restaurants & 477 & 576 & 648 & 653 & 670 & 724 \\
\hline Transport and communications & 1,533 & 2,083 & 2,382 & 2,671 & 3,019 & 3,341 \\
\hline Transport and storage & 975 & 1,289 & 1,409 & 1,497 & 1,639 & 1,848 \\
\hline Post and telecommunications & 558 & 794 & 973 & 1,173 & 1,380 & 1,493 \\
\hline Finance, real estate, and business services & 3,131 & 3,562 & 3,973 & 4,361 & 4,779 & 7,115 \\
\hline Financial intermediation & 964 & 1,088 & 1,249 & 1,213 & 1,455 & 1,562 \\
\hline Financial services indirectly measured & -330 & -359 & -432 & -394 & -440 & -544 \\
\hline Real estate and business services & 2,497 & 2,832 & 3,156 & 3,542 & 3,764 & 4,073 \\
\hline Owner-occupied dwellings & 1,317 & 1,449 & 1,593 & 1,748 & 1,861 & 2,024 \\
\hline Other real estate and business services & 1,180 & 1,382 & 1,563 & 1,794 & 1,902 & 2,048 \\
\hline Community, social, and personal services & 216 & 244 & 281 & 282 & 320 & 354 \\
\hline General government & 5,810 & 6,553 & 6,863 & 7,142 & 7,752 & 8,269 \\
\hline Other producers & 487 & 558 & 606 & 647 & 673 & 721 \\
\hline Subtotal, tertiary industries & 14,659 & 17,002 & 18,740 & 19,722 & 21,448 & 23,692 \\
\hline Taxes less subsidies on products & 2,771 & 3,161 & 2,655 & 3,567 & 3,913 & 4,273 \\
\hline GDP at current market prices & 27,686 & 32,908 & 33,842 & 36,496 & 39,711 & 46,971 \\
\hline
\end{tabular}

Sources: Namibian authorities; and IMF staff estimates.

$1 /$ Columns may not sum due to rounding error. 
Table 3. Namibia: Sector Shares of GDP at Current Prices, 2001-06

\begin{tabular}{|c|c|c|c|c|c|c|}
\hline & 2001 & 2002 & 2003 & 2004 & 2005 & 2006 \\
\hline & \multicolumn{6}{|c|}{ (In percent of GDP) } \\
\hline GDP at basic prices & 90.0 & 90.4 & 92.2 & 90.2 & 90.1 & 90.9 \\
\hline Agriculture & 4.1 & 5.1 & 5.4 & 5.1 & 6.0 & 6.2 \\
\hline Commercial agriculture & 2.6 & 4.0 & 4.0 & 3.5 & 4.2 & 4.1 \\
\hline Subsistence agriculture & 1.5 & 1.1 & 1.4 & 1.6 & 1.8 & 2.1 \\
\hline Fishing & 5.2 & 4.9 & 5.2 & 4.2 & 4.8 & 4.2 \\
\hline Mining and quarrying & 13.2 & 13.9 & 8.8 & 9.6 & 8.5 & 11.7 \\
\hline Diamond mining & 10.3 & 10.4 & 7.8 & 8.4 & 7.0 & 8.6 \\
\hline Other mining and quarrying & 2.9 & 3.5 & 1.0 & 1.2 & 1.5 & 3.1 \\
\hline Subtotal, primary industries & 22.6 & 23.9 & 19.3 & 18.9 & 19.4 & 22.1 \\
\hline Manufacturing & 9.4 & 10.0 & 11.4 & 11.0 & 10.2 & 12.0 \\
\hline Meat processing & 0.5 & 0.4 & 0.4 & 0.3 & 0.3 & 0.2 \\
\hline Fish processing & 1.8 & 2.1 & 2.6 & 2.1 & 1.2 & 1.3 \\
\hline Food products and beverages & 4.4 & 4.6 & 4.9 & 4.6 & 4.5 & 4.2 \\
\hline Other manufacturing & 2.7 & 2.9 & 3.6 & 3.9 & 4.3 & 6.3 \\
\hline Electricity and water & 2.2 & 2.6 & 3.0 & 3.3 & 3.4 & 2.7 \\
\hline Construction & 2.8 & 2.2 & 3.0 & 3.0 & 3.1 & 3.7 \\
\hline Subtotal, secondary industries & 14.5 & 14.8 & 17.4 & 17.3 & 16.7 & 18.4 \\
\hline Wholesale and retail trade and repairs & 10.8 & 10.4 & 11.8 & 10.9 & 10.7 & 11.1 \\
\hline Hotels and restaurants & 1.7 & 1.7 & 1.9 & 1.8 & 1.7 & 1.5 \\
\hline Transport and communications & 5.5 & 6.3 & 7.0 & 7.3 & 7.6 & 7.1 \\
\hline Transport and storage & 3.5 & 3.9 & 4.2 & 4.1 & 4.1 & 3.9 \\
\hline Post and telecommunications & 2.0 & 2.4 & 2.9 & 3.2 & 3.5 & 3.2 \\
\hline Finance, real estate, and business services & 11.3 & 10.8 & 11.7 & 11.9 & 12.0 & 15.1 \\
\hline Financial intermediation & 3.5 & 3.3 & 3.7 & 3.3 & 3.7 & 3.3 \\
\hline Financial services indirectly measured & -1.2 & -1.1 & -1.3 & -1.1 & -1.1 & -1.2 \\
\hline Real estate and business services & 9.0 & 8.6 & 9.3 & 9.7 & 9.5 & 8.7 \\
\hline Owner-occupied dwellings & 4.8 & 4.4 & 4.7 & 4.8 & 4.7 & 4.3 \\
\hline Other real estate and business services & 4.3 & 4.2 & 4.6 & 4.9 & 4.8 & 4.4 \\
\hline Community, social, and personal services & 0.8 & 0.7 & 0.8 & 0.8 & 0.8 & 0.8 \\
\hline General government & 21.0 & 19.9 & 20.3 & 19.6 & 19.5 & 17.6 \\
\hline Other producers & 1.8 & 1.7 & 1.8 & 1.8 & 1.7 & 1.5 \\
\hline Subtotal, tertiary industries & 52.9 & 51.7 & 55.4 & 54.0 & 54.0 & 50.4 \\
\hline Taxes less subsidies on products & 10.0 & 9.6 & 7.8 & 9.8 & 9.9 & 9.1 \\
\hline GDP at market prices & 100.0 & 100.0 & 100.0 & 100.0 & 100.0 & 100.0 \\
\hline
\end{tabular}

Sources: Namibian authorities; and IMF staff estimates. 
Table 4. Namibia: GDP by Industrial Origin at Constant 1995 Prices, 2001-06 1/

\begin{tabular}{|c|c|c|c|c|c|c|}
\hline & 2001 & 2002 & 2003 & 2004 & 2005 & 2006 \\
\hline & \multicolumn{6}{|c|}{ (In millions of Namibia dollars) } \\
\hline GDP at constant basic prices & 13,488 & 14,439 & 14,986 & 16,088 & 16,938 & 17,650 \\
\hline Agriculture & 899 & 975 & 1,010 & 1,019 & 1,130 & 1,175 \\
\hline Commercial agriculture & 589 & 723 & 755 & 681 & 738 & 746 \\
\hline Subsistence agriculture & 310 & 252 & 255 & 338 & 391 & 430 \\
\hline Fishing & 631 & 703 & 732 & 666 & 643 & 612 \\
\hline Mining and quarrying & 1,117 & 1,296 & 1,237 & 1,688 & 1,665 & 1,922 \\
\hline Diamond mining & 803 & 942 & 909 & 1,260 & 1,217 & 1,524 \\
\hline Other mining and quarrying & 314 & 355 & 328 & 428 & 448 & 398 \\
\hline Subtotal, primary industries & 2,647 & 2,974 & 2,979 & 3,372 & 3,438 & 3,709 \\
\hline Manufacturing & 1,657 & 1,816 & 1,911 & 1,968 & 2,009 & 1,842 \\
\hline Meat processing & 107 & 109 & 97 & 88 & 95 & 84 \\
\hline Fish processing & 204 & 183 & 277 & 269 & 256 & 159 \\
\hline Food products and beverages & 808 & 875 & 872 & 885 & 929 & 980 \\
\hline Other manufacturing & 538 & 648 & 665 & 726 & 728 & 618 \\
\hline Electricity and water & 228 & 230 & 266 & 279 & 315 & 299 \\
\hline Construction & 527 & 459 & 564 & 562 & 586 & 777 \\
\hline Subtotal, secondary industries & 2,412 & 2,505 & 2,741 & 2,808 & 2,910 & 2,918 \\
\hline Wholesale and retail trade and repairs & 1,496 & 1,607 & 1,674 & 1,801 & 1,915 & 2,117 \\
\hline Hotels and restaurants & 292 & 316 & 332 & 321 & 322 & 332 \\
\hline Transport and communications & 1,196 & 1,332 & 1,372 & 1,558 & 1,815 & 2,014 \\
\hline Transport and storage & 725 & 837 & 753 & 816 & 863 & 964 \\
\hline Post and telecommunications & 471 & 494 & 619 & 741 & 952 & 1,050 \\
\hline Finance, real estate, and business services & 1,733 & 1,854 & 1,958 & 2,123 & 2,263 & 2,316 \\
\hline Financial intermediation & 498 & 514 & 564 & 646 & 768 & 788 \\
\hline Financial services indirectly measured & -158 & -155 & -178 & -206 & -233 & -276 \\
\hline Real estate and business services & 1,393 & 1,494 & 1,572 & 1,683 & 1,728 & 1,804 \\
\hline Owner-occupied dwellings & 711 & 740 & 759 & 778 & 816 & 861 \\
\hline Other real estate and business services & 682 & 754 & 813 & 906 & 912 & 943 \\
\hline Community, social, and personal services & 133 & 137 & 144 & 135 & 140 & 144 \\
\hline General government & 3,281 & 3,408 & 3,475 & 3,650 & 3,811 & 3,769 \\
\hline Other producers & 298 & 307 & 310 & 318 & 324 & 330 \\
\hline Subtotal, tertiary industries & 8,428 & 8,959 & 9,266 & 9,907 & 10,591 & 11,023 \\
\hline Taxes less subsidies on products & 1,974 & 2,055 & 2,083 & 2,112 & 2,140 & 2,204 \\
\hline GDP at constant 1995 prices & 15,462 & 16,494 & 17,069 & 18,201 & 19,077 & 19,854 \\
\hline \multicolumn{7}{|l|}{ Memorandum items: } \\
\hline GDP at current basic prices & 24,916 & 29,747 & 31,187 & 32,930 & 35,798 & 42,698 \\
\hline GDP deflator & 179 & 200 & 198 & 201 & 208 & 237 \\
\hline GDP at current market prices & 27,686 & 32,908 & 33,842 & 36,496 & 39,711 & 46,971 \\
\hline
\end{tabular}

Source: Central Bureau of Statistics.

1 / Columns may not sum due to rounding error. 
Table 5. Namibia: GDP Growth by Industrial Origin at Constant 1995 Prices, 2001-06

\begin{tabular}{|c|c|c|c|c|c|c|}
\hline & 2001 & 2002 & 2003 & 2004 & 2005 & 2006 \\
\hline & \multicolumn{6}{|c|}{ (Annual percentage change) } \\
\hline GDP at constant basic prices & 2.1 & 7.1 & 3.8 & 7.4 & 5.3 & 4.2 \\
\hline Agriculture & -14.9 & 8.5 & 3.6 & 0.9 & 10.9 & 4.0 \\
\hline Commercial agriculture & -9.2 & 22.8 & 4.4 & -9.8 & 8.4 & 1.1 \\
\hline Subsistence agriculture & -24.0 & -18.7 & 1.2 & 32.5 & 15.7 & 10.0 \\
\hline Fishing & -1.5 & 11.4 & 4.2 & -9.0 & -3.5 & -4.8 \\
\hline Mining and quarrying & -6.1 & 16.0 & -4.6 & 36.5 & -1.4 & 15.4 \\
\hline Diamond mining & -5.1 & 17.3 & -3.5 & 38.6 & -3.4 & 25.2 \\
\hline Other mining and quarrying & -8.5 & 13.1 & -7.6 & 30.5 & 4.7 & -11.2 \\
\hline Subtotal, primary industries & -8.3 & 12.4 & 0.2 & 13.2 & 2.0 & 7.9 \\
\hline Manufacturing & 5.5 & 9.6 & 5.2 & 3.0 & 2.1 & -8.3 \\
\hline Meat processing & 6.4 & 2.1 & -11.2 & -9.3 & 8.0 & -11.6 \\
\hline Fish processing & -15.3 & -10.3 & 51.4 & -2.9 & -4.8 & -37.9 \\
\hline Food products and beverages & 4.4 & 8.3 & -0.4 & 1.5 & 5.0 & 5.5 \\
\hline Other manufacturing & 18.3 & 20.5 & 2.6 & 9.2 & 0.3 & -15.1 \\
\hline Electricity and water & -23.8 & 1.1 & 15.4 & 4.9 & 12.9 & -5.1 \\
\hline Construction & 53.1 & -13.0 & 22.9 & -0.4 & 4.3 & 32.6 \\
\hline Subtotal, secondary industries & 8.9 & 3.9 & 9.4 & 2.4 & 3.6 & 0.3 \\
\hline Wholesale and retail trade and repairs & 2.8 & 7.4 & 4.2 & 7.6 & 6.3 & 10.5 \\
\hline Hotels and restaurants & 8.4 & 8.4 & 4.9 & -3.3 & 0.3 & 3.1 \\
\hline Transport and communications & 14.0 & 11.4 & 3.0 & 13.6 & 16.5 & 11.0 \\
\hline Transport and storage & 8.1 & 15.4 & -10.0 & 8.4 & 5.8 & 11.7 \\
\hline Post and telecommunications & 24.3 & 5.0 & 25.3 & 19.7 & 28.5 & 10.3 \\
\hline Finance, real estate, and business services & 3.4 & 7.0 & 5.6 & 8.4 & 6.6 & 2.3 \\
\hline Financial intermediation & 1.7 & 3.3 & 9.7 & 14.5 & 18.9 & 2.6 \\
\hline Financial services indirectly measured & 4.5 & -1.9 & 15.1 & 15.7 & 13.1 & 18.5 \\
\hline Real estate and business services & 4.1 & 7.3 & 5.2 & 7.1 & 2.7 & 4.4 \\
\hline Owner-occupied dwellings & 2.5 & 4.1 & 2.6 & 2.5 & 4.9 & 5.5 \\
\hline Other real estate and business services & 5.8 & 10.6 & 7.8 & 11.4 & 0.7 & 3.4 \\
\hline Community, social, and personal services & 0.2 & 2.9 & 5.2 & -6.3 & 3.7 & 2.9 \\
\hline General government & 1.4 & 3.9 & 2.0 & 5.0 & 4.4 & -1.1 \\
\hline Other producers & 2.2 & 2.9 & 1.0 & 2.6 & 1.9 & 1.9 \\
\hline Subtotal, tertiary industries & 3.9 & 6.3 & 3.4 & 6.9 & 6.9 & 4.1 \\
\hline Taxes less subsidies on products & 4.5 & 4.1 & 1.4 & 1.4 & 1.3 & 3.0 \\
\hline GDP at constant 1995 prices & 2.4 & 6.7 & 3.5 & 6.6 & 4.8 & 4.1 \\
\hline \multicolumn{7}{|l|}{ Memorandum items: } \\
\hline GDP at current basic prices & 16.6 & 19.4 & 4.8 & 5.6 & 8.7 & 19.3 \\
\hline GDP deflator & 14.1 & 11.4 & -0.6 & 1.1 & 3.8 & 13.7 \\
\hline GDP at current market prices & 16.9 & 18.9 & 2.8 & 7.8 & 8.8 & 18.3 \\
\hline
\end{tabular}

Source: Central Bureau of Statistics. 
Table 6. Namibia: Expenditure on GDP, 2001-06 1/

\begin{tabular}{|c|c|c|c|c|c|c|}
\hline & 2001 & 2002 & 2003 & 2004 & 2005 & 2006 \\
\hline & \multicolumn{6}{|c|}{ (In millions of Namibia dollars) } \\
\hline Expenditure on GDP at market prices & 27,686 & 32,908 & 33,842 & 36,496 & 39,711 & 46,971 \\
\hline Gross domestic expenditure & 30,434 & 33,477 & 37,853 & 39,424 & 40,874 & 46,314 \\
\hline Final consumption expenditure & 23,949 & 26,981 & 27,766 & 30,059 & 30,617 & 33,758 \\
\hline Private & 16,094 & 18,289 & 18,797 & 21,031 & 20,882 & 23,204 \\
\hline General government & 7,856 & 8,692 & 8,969 & 9,027 & 9,734 & 10,554 \\
\hline Gross capital formation & 6,073 & 6,964 & 9,867 & 9,190 & 9,727 & 12,235 \\
\hline Public & 2,417 & 2,052 & 2,383 & 2,673 & 2,640 & 2,923 \\
\hline Producers of government services & 1,059 & 1,042 & 1,058 & 1,340 & 1,497 & 1,673 \\
\hline Public corporations and enterprises & 1,358 & 1,010 & 1,325 & 1,333 & 1,143 & 1,250 \\
\hline Private & 3,656 & 4,912 & 7,484 & 6,692 & 7,087 & 9,312 \\
\hline Changes in inventories $2 /$ & 412 & -468 & 220 & 175 & 530 & 321 \\
\hline Discrepency 2/ & -968 & 77 & $-2,790$ & -693 & 197 & 799 \\
\hline Net exports & $-1,780$ & -646 & $-1,221$ & $-2,235$ & $-1,360$ & -142 \\
\hline Exports of goods and services & 12,446 & 16,320 & 17,396 & 16,757 & 18,901 & 24,534 \\
\hline \multirow[t]{2}{*}{ Imports of goods and services } & 14,226 & 16,966 & 18,617 & 18,992 & 20,261 & 24,676 \\
\hline & \multicolumn{6}{|c|}{ (Percent of expenditure on GDP) } \\
\hline Gross domestic expenditure & 109.9 & 101.7 & 111.9 & 108.0 & 102.9 & 98.6 \\
\hline Final consumption expenditure & 86.5 & 82.0 & 82.0 & 82.4 & 77.1 & 71.9 \\
\hline General government & 28.4 & 26.4 & 26.5 & 24.7 & 24.5 & 22.5 \\
\hline Private & 58.1 & 55.6 & 55.5 & 57.6 & 52.6 & 49.4 \\
\hline Gross capital formation & 21.9 & 21.2 & 29.2 & 25.2 & 24.5 & 26.0 \\
\hline Public & 8.7 & 6.2 & 7.0 & 7.3 & 6.6 & 6.2 \\
\hline Private & 13.2 & 14.9 & 22.1 & 18.3 & 17.8 & 19.8 \\
\hline Changes in inventories 2/ & 1.5 & -1.4 & 0.7 & 0.5 & 1.3 & 0.7 \\
\hline Discrepency $2 /$ & -3.5 & 0.2 & -8.2 & -1.9 & 0.5 & 1.7 \\
\hline Net exports & -6.4 & -2.0 & -3.6 & -6.1 & -3.4 & -0.3 \\
\hline Exports of goods and services & 45.0 & 49.6 & 51.4 & 45.9 & 47.6 & 52.2 \\
\hline Imports of goods and services & 51.4 & 51.6 & 55.0 & 52.0 & 51.0 & 52.5 \\
\hline
\end{tabular}

Sources: Namibian authorities; and IMF staff estimates.

$1 /$ Columns may not sum due to rounding error.

2/ Changes in inventories includes only livestock, ores and minerals. Discrepency includes other changes in inventories. 


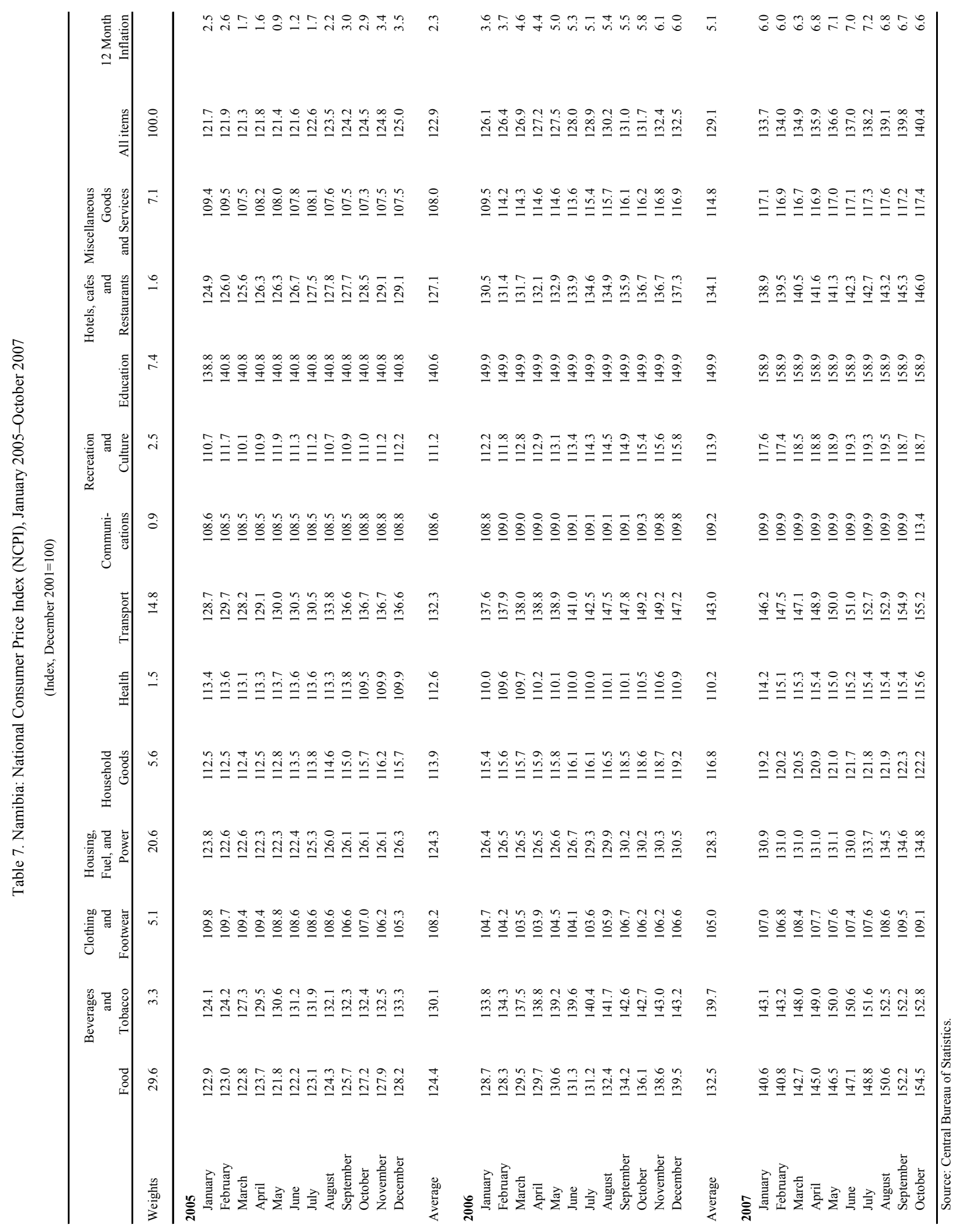


Table 8. Namibia: Financial Operations of the Central Government, 2001/02-2006/07 1/

\begin{tabular}{|c|c|c|c|c|c|c|}
\hline & $2001 / 02$ & $2002 / 03$ & $2003 / 04$ & $2004 / 05$ & $2005 / 06$ & $2006 / 07$ \\
\hline & \multicolumn{6}{|c|}{ (In millions of Namibia dollars) } \\
\hline Revenue and grants & 8,960 & 10,469 & 9,754 & 11,388 & 13,075 & 16,893 \\
\hline Revenue & 8,902 & 10,435 & 9,720 & 11,317 & 13,036 & 16,843 \\
\hline Tax revenue & 8,054 & 9,196 & 8,633 & 10,358 & 11,887 & 15,734 \\
\hline Personal income tax & 1,833 & 2,181 & 2,334 & 2,662 & 2,905 & 3,374 \\
\hline Corporate income tax & 1,335 & 2,113 & 1,198 & 1,222 & 1,573 & 2,161 \\
\hline Diamond mining & 764 & 1,157 & 175 & 301 & 199 & 360 \\
\hline Other mining & 106 & 284 & 3 & 8 & 1 & 351 \\
\hline Non-mining & 465 & 672 & 1,020 & 913 & 1,373 & 1,451 \\
\hline VAT and sales taxes & 1,938 & 2,009 & 1,756 & 1,828 & 3,108 & 3,002 \\
\hline International taxes (SACU receipts) 2/ & 2,641 & 2,597 & 3,036 & 4,207 & 3,892 & 6,698 \\
\hline Other & 306 & 296 & 309 & 439 & 408 & 500 \\
\hline Nontax revenue & 847 & 1,239 & 1,087 & 959 & 1,150 & 1,109 \\
\hline Diamond royalties & 286 & 479 & 302 & 385 & 405 & 482 \\
\hline Administrative fees, including license revenu & 258 & 388 & 461 & 349 & 519 & 412 \\
\hline Other & 303 & 372 & 324 & 225 & 226 & 215 \\
\hline Grants (tied) & 58 & 34 & 34 & 70 & 39 & 50 \\
\hline Expenditures & 10,256 & 11,573 & 12,335 & 12,640 & 13,279 & 15,243 \\
\hline Current expenditure & 8,717 & 9,482 & 10,387 & 10,684 & 11,614 & 12,512 \\
\hline Personnel & 4,326 & 4,709 & 5,117 & 5,446 & 5,889 & 6,213 \\
\hline Goods and services & 2,034 & 2,057 & 2,150 & 1,957 & 2,018 & 2,289 \\
\hline Interest payments & 587 & 823 & 865 & 999 & 1,162 & 1,263 \\
\hline Domestic & 559 & 772 & 814 & 930 & 1,080 & 1,169 \\
\hline Foreign & 28 & 52 & 51 & 69 & 82 & 94 \\
\hline Subsidies and current transfers & 1,770 & 1,893 & 2,255 & 2,282 & 2,546 & 2,747 \\
\hline Other & 0 & 0 & 0 & 0 & 0 & 0 \\
\hline Capital expenditure & 1,082 & 1,457 & 1,561 & 1,627 & 1,490 & 2,097 \\
\hline Acquisition of capital assets & 1,038 & 1,370 & 1,470 & 1,421 & 1,384 & $\ldots$ \\
\hline Capital transfers & 44 & 87 & 91 & 206 & 106 & $\ldots$ \\
\hline Net lending & 456 & 634 & 387 & 329 & 175 & 633 \\
\hline Overall balance $3 /$ & $-1,296$ & $-1,104$ & $-2,581$ & $-1,253$ & -204 & 1,650 \\
\hline Primary balance 3 / & -709 & -280 & $-1,716$ & -253 & 958 & 2,912 \\
\hline Statistical discrepancy & -132 & -27 & -59 & 200 & 9 & -66 \\
\hline Financing & 1,164 & 1,076 & 2,522 & 1,452 & 213 & $-1,716$ \\
\hline Domestic & 1,062 & 815 & 2,306 & 1,254 & 101 & $-2,561$ \\
\hline External & 103 & 261 & 216 & 198 & 112 & 162 \\
\hline Disbursements & 110 & 275 & 235 & 226 & 146 & 196 \\
\hline Amortization & -7 & -14 & -19 & -27 & -34 & -34 \\
\hline Privatization & 0 & 0 & 0 & 0 & 0 & 683 \\
\hline
\end{tabular}

Sources: Namibian authorities; and IMF staff estimates.

1/ Fiscal year begins April 1.

2/ Transfers from the common revenue pool (customs and excise) of the Southern African Customs Union.

3/ Includes externally financed project spending (except for roads) that is not channeled through the state account. 
Table 9. Namibia: Central Government Revenue and Grants, 2001/02-2006/07 1/

\begin{tabular}{|c|c|c|c|c|c|c|}
\hline & $2001 / 02$ & $2002 / 03$ & $2003 / 04$ & $2004 / 05$ & $2005 / 06$ & $\begin{array}{r}2006 / 07 \\
\text { Est. }\end{array}$ \\
\hline & \multicolumn{6}{|c|}{ (In millions of Namibia dollars) } \\
\hline Tax revenue & 8,054 & 9,196 & 8,633 & 10,358 & 11,887 & 15,734 \\
\hline Taxes on income/profits & 3,286 & 4,442 & 3,618 & 4,024 & 4,576 & 5,676 \\
\hline Personal & 1,833 & 2,181 & 2,334 & 2,662 & 2,905 & 3,374 \\
\hline Corporate & 1,335 & 2,113 & 1,198 & 1,222 & 1,573 & 2,161 \\
\hline Mining & 871 & 1,441 & 179 & 309 & 200 & 711 \\
\hline Diamond & 764 & 1,157 & 175 & 301 & 199 & 360 \\
\hline Other mining & 106 & 284 & 3 & 8 & 1 & 351 \\
\hline Other sectors & 465 & 672 & 1,020 & 913 & 1,373 & 1,451 \\
\hline Other income/profits taxes & 117 & 149 & 86 & 140 & 97 & 141 \\
\hline Property taxes & 64 & 79 & 75 & 86 & 110 & 142 \\
\hline Taxes on goods and services & 2,063 & 2,077 & 1,903 & 2,041 & 3,309 & 3,218 \\
\hline VAT and sales taxes & 1,938 & 2,009 & 1,756 & 1,828 & 3,108 & 3,002 \\
\hline Fuel levy & 58 & -7 & 64 & 119 & 88 & 86 \\
\hline Stamp duties & 68 & 76 & 83 & 94 & 113 & 130 \\
\hline Taxes on international trade (SACU receipts) 2/ & 2,641 & 2,597 & 3,036 & 4,207 & 3,892 & 6,698 \\
\hline Nontax revenue & 847 & 1,239 & 1,087 & 959 & 1,150 & 1,109 \\
\hline Property income & 571 & 831 & 607 & 594 & 613 & 678 \\
\hline Diamond royalties & 286 & 479 & 302 & 385 & 405 & 482 \\
\hline Fishing quota levies & 108 & 128 & 118 & 104 & 70 & 98 \\
\hline Interest on loans, investments, and central bank deposits & 54 & 62 & 27 & 30 & 44 & 60 \\
\hline Dividends from parastatals & 124 & 81 & 79 & 15 & 45 & 9 \\
\hline Compensation for use of the Rand & 0 & 81 & 81 & 60 & 50 & 29 \\
\hline Administrative fees, including license revenues & 258 & 388 & 461 & 349 & 519 & 412 \\
\hline Fines and forfeitures & 18 & 20 & 19 & 17 & 18 & 19 \\
\hline Total revenue & 8,902 & 10,435 & 9,720 & 11,317 & 13,036 & 16,843 \\
\hline Grants (tied) & 58 & 34 & 34 & 70 & 39 & 50 \\
\hline Recurrent activity & 3 & 10 & 34 & 70 & 39 & 0 \\
\hline Development projects & 55 & 24 & 0 & 0 & 0 & 50 \\
\hline Revenue and grants & 8,960 & 10,469 & 9,754 & 11,388 & 13,075 & 16,893 \\
\hline \multicolumn{7}{|l|}{ Memorandum item: } \\
\hline GDP at current market prices & 28,992 & 33,142 & 34,506 & 37,300 & 41,526 & 48,280 \\
\hline
\end{tabular}

Sources: Namibian authorities; and IMF staff estimates.

1/ Fiscal year begins April 1.

2/ Transfers from the common revenue pool (customs and excise) of the Southern African Customs Union. 
Table 10. Namibia: Central Government Revenue and Grants (Percent of GDP), 2001/02-2006/07 1/

\begin{tabular}{|c|c|c|c|c|c|c|}
\hline & $2001 / 02$ & $2002 / 03$ & $2003 / 04$ & $2004 / 05$ & $2005 / 06$ & $\begin{array}{r}2006 / 07 \\
\text { Est. }\end{array}$ \\
\hline Tax revenue & 27.8 & 27.7 & 25.0 & 27.8 & 28.6 & 32.6 \\
\hline Taxes on income/profits & 11.3 & 13.4 & 10.5 & 10.8 & 11.0 & 11.8 \\
\hline Personal & 6.3 & 6.6 & 6.8 & 7.1 & 7.0 & 7.0 \\
\hline Corporate & 4.6 & 6.4 & 3.5 & 3.3 & 3.8 & 4.5 \\
\hline Mining & 3.0 & 4.3 & 0.5 & 0.8 & 0.5 & 1.5 \\
\hline Diamond & 2.6 & 3.5 & 0.5 & 0.8 & 0.5 & 0.7 \\
\hline Other mining & 0.4 & 0.9 & 0.0 & 0.0 & 0.0 & 0.7 \\
\hline Other sectors & 1.6 & 2.0 & 3.0 & 2.4 & 3.3 & 3.0 \\
\hline Other income/profits taxes & 0.4 & 0.4 & 0.3 & 0.4 & 0.2 & 0.3 \\
\hline Property taxes & 0.2 & 0.2 & 0.2 & 0.2 & 0.3 & 0.3 \\
\hline Taxes on goods and services & 7.1 & 6.3 & 5.5 & 5.5 & 8.0 & 6.7 \\
\hline VAT and sales taxes & 6.7 & 6.1 & 5.1 & 4.9 & 7.5 & 6.2 \\
\hline Fuel levy & 0.2 & 0.0 & 0.2 & 0.3 & 0.2 & 0.2 \\
\hline Stamp duties & 0.2 & 0.2 & 0.2 & 0.3 & 0.3 & 0.3 \\
\hline Taxes on international trade (SACU receipts) 2/ & 9.1 & 7.8 & 8.8 & 11.3 & 9.4 & 13.9 \\
\hline Nontax revenue & 2.9 & 3.7 & 3.2 & 2.6 & 2.8 & 2.3 \\
\hline Property income & 2.0 & 2.5 & 1.8 & 1.6 & 1.5 & 1.4 \\
\hline Diamond royalties & 1.0 & 1.4 & 0.9 & 1.0 & 1.0 & 1.0 \\
\hline Fishing quota levies & 0.4 & 0.4 & 0.3 & 0.3 & 0.2 & 0.2 \\
\hline Interest on loans, investments, and central bank deposits & 0.2 & 0.2 & 0.1 & 0.1 & 0.1 & 0.1 \\
\hline Dividends from parastatals & 0.4 & 0.2 & 0.2 & 0.0 & 0.1 & 0.0 \\
\hline Compensation for use of the Rand & 0.0 & 0.2 & 0.2 & 0.2 & 0.1 & 0.1 \\
\hline Administrative fees, including license revenues & 0.9 & 1.2 & 1.3 & 0.9 & 1.3 & 0.9 \\
\hline Fines and forfeitures & 0.1 & 0.1 & 0.1 & 0.0 & 0.0 & 0.0 \\
\hline Total revenue & 30.7 & 31.5 & 28.2 & 30.3 & 31.4 & 34.9 \\
\hline Grants (tied) & 0.2 & 0.1 & 0.1 & 0.2 & 0.1 & 0.1 \\
\hline Recurrent activity & 0.0 & 0.0 & 0.1 & 0.2 & 0.1 & 0.0 \\
\hline Development projects & 0.2 & 0.1 & 0.0 & 0.0 & 0.0 & 0.1 \\
\hline Revenue and grants & 30.9 & 31.6 & 28.3 & 30.5 & 31.5 & 35.0 \\
\hline
\end{tabular}

Sources: Namibian authorities; and IMF staff estimates.

1/ Fiscal year begins April 1.

2/ Transfers from the common revenue pool (customs and excise) of the Southern African Customs Union. 
Table 11. Namibia: Central Government Expenditure, 2001/02-2006/07 1/

\begin{tabular}{|c|c|c|c|c|c|c|}
\hline & $2001 / 02$ & $2002 / 03$ & $2003 / 04$ & $2004 / 05$ & $2005 / 06$ & $\begin{array}{r}2006 / 07 \\
\text { Est. }\end{array}$ \\
\hline & \multicolumn{6}{|c|}{ (In millions of Namibia dollars) } \\
\hline Current expenditure & 8,717 & 9,482 & 10,387 & 10,684 & 11,614 & 12,512 \\
\hline Personnel & 4,326 & 4,709 & 5,117 & 5,446 & 5,889 & 6,213 \\
\hline Wages and salaries & $\ldots$ & $\ldots$ & $\ldots$ & 4,729 & 5,144 & $\ldots$ \\
\hline Pension contributions & $\ldots$ & $\ldots$ & $\ldots$ & 588 & 628 & $\ldots$ \\
\hline Cash benefits & $\ldots$ & $\ldots$ & $\ldots$ & 129 & 117 & $\ldots$ \\
\hline Goods and services & 2,034 & 2,057 & 2,150 & 1,957 & 2,018 & 2,289 \\
\hline Interest payments & 587 & 823 & 865 & 999 & 1,162 & 1,263 \\
\hline Domestic & 559 & 772 & 814 & 930 & 1,080 & 1,169 \\
\hline Foreign & 28 & 52 & 51 & 69 & 82 & 94 \\
\hline Subsidies and current transfers & 1,770 & 1,893 & 2,255 & 2,282 & 2,546 & 2,747 \\
\hline Other current expenditure & 0 & 0 & 0 & 0 & 0 & 0 \\
\hline Capital expenditure & 1,082 & 1,457 & 1,561 & 1,627 & 1,490 & 2,097 \\
\hline Acquisition of capital assets 2/ & 1,038 & 1,370 & 1,470 & 1,421 & 1,384 & $\ldots$ \\
\hline Capital transfers & 44 & 87 & 91 & 206 & 106 & $\ldots$ \\
\hline Net lending & 456 & 634 & 387 & 329 & 175 & 633 \\
\hline Lending & 478 & 650 & 400 & 366 & 208 & 651 \\
\hline Repayments & -21 & -16 & -13 & -37 & -32 & -17 \\
\hline Total expenditure and net lending & 10,256 & 11,573 & 12,335 & 12,640 & 13,279 & 15,243 \\
\hline \multicolumn{7}{|l|}{ Memorandum item: } \\
\hline GDP at current market prices & 28,992 & 33,142 & 34,506 & 37,300 & 41,526 & 48,280 \\
\hline
\end{tabular}

Sources: Namibian authorities; and IMF staff estimates.

1/ Fiscal year begins April 1.

2/ This includes externally financed project spending (except for roads) that is not channeled through the state account. 
Table 12. Namibia: Central Government Expenditure (Percent of GDP), 2001/02-2006/07 1/

\begin{tabular}{|c|c|c|c|c|c|c|}
\hline & $2001 / 02$ & $2002 / 03$ & $2003 / 04$ & $2004 / 05$ & $2005 / 06$ & $\begin{array}{r}2006 / 07 \\
\text { Est. }\end{array}$ \\
\hline Current expenditure & 30.1 & 28.6 & 30.1 & 28.6 & 28.0 & 25.9 \\
\hline Personnel & 14.9 & 14.2 & 14.8 & 14.6 & 14.2 & 12.9 \\
\hline Wages and salaries & $\cdots$ & $\ldots$ & $\cdots$ & 12.7 & 12.4 & $\cdots$ \\
\hline Pension contributions & $\cdots$ & $\ldots$ & $\cdots$ & 1.6 & 1.5 & ... \\
\hline Cash benefits & $\ldots$ & $\ldots$ & $\ldots$ & 0.3 & 0.3 & $\ldots$ \\
\hline Goods and services & 7.0 & 6.2 & 6.2 & 5.2 & 4.9 & 4.7 \\
\hline Interest payments & 2.0 & 2.5 & 2.5 & 2.7 & 2.8 & 2.6 \\
\hline Domestic & 1.9 & 2.3 & 2.4 & 2.5 & 2.6 & 2.4 \\
\hline Foreign & 0.1 & 0.2 & 0.1 & 0.2 & 0.2 & 0.2 \\
\hline Subsidies and current transfers & 6.1 & 5.7 & 6.5 & 6.1 & 6.1 & 5.7 \\
\hline Other current expenditure & 0.0 & 0.0 & 0.0 & 0.0 & 0.0 & 0.0 \\
\hline Capital expenditure & 3.7 & 4.4 & 4.5 & 4.4 & 3.6 & 4.3 \\
\hline Acquisition of capital assets 2/ & 3.6 & 4.1 & 4.3 & 3.8 & 3.3 & $\ldots$ \\
\hline Capital transfers & 0.2 & 0.3 & 0.3 & 0.6 & 0.3 & ... \\
\hline Net lending & 1.6 & 1.9 & 1.1 & 0.9 & 0.4 & 1.3 \\
\hline Lending & 1.6 & 2.0 & 1.2 & 1.0 & 0.5 & 1.3 \\
\hline Repayments & -0.1 & 0.0 & 0.0 & -0.1 & -0.1 & 0.0 \\
\hline Total expenditure and net lending & 35.4 & 34.9 & 35.7 & 33.9 & 32.0 & 31.6 \\
\hline
\end{tabular}

Sources: Namibian authorities; and IMF staff estimates.

1/ Fiscal year begins April 1.

2/ This includes externally financed project spending (except for roads) that is not channeled through the state account. 
Table 13. Namibia: Outstanding Debt of Central Government, 2001/02-2006/07 1/

\begin{tabular}{|c|c|c|c|c|c|c|}
\hline & $2001 / 02$ & $2002 / 03$ & 2003/04 & $2004 / 05$ & $2005 / 06$ & $2006 / 07$ \\
\hline & \multicolumn{6}{|c|}{ (In millions of Namibia dollars) } \\
\hline Domestic debt & 5,947 & 6,712 & 8,606 & 10,543 & 10,690 & 10,928 \\
\hline Treasury bills & 3,211 & 3,618 & 5,041 & 5,615 & 4,763 & 3,950 \\
\hline 91 days & 1,449 & 1,004 & 300 & 310 & 226 & 300 \\
\hline 182 days & 1,190 & 1,236 & 2,190 & 1,180 & 900 & 820 \\
\hline 365 days & 572 & 1,378 & 2,551 & 4,125 & 3,637 & 2,830 \\
\hline Internal registered stock (IRS) & 2,736 & 3,094 & 3,565 & 4,927 & 5,927 & 6,978 \\
\hline less than 2 years term-to-maturity & 669 & 1,164 & 1,069 & 1,816 & 1,778 & 1,778 \\
\hline $3-5$ years term-to-maturity & 985 & 442 & 655 & 1,702 & 1,750 & 2,597 \\
\hline $6-10$ years term-to-maturity & 1,082 & 1,213 & 1,263 & 1,114 & 1,863 & 1,647 \\
\hline above 11 years term-to-maturity & 0 & 275 & 579 & 296 & 536 & 955 \\
\hline Foreign debt & 1,561 & 1,212 & 1,607 & 2,016 & 1,843 & 2,710 \\
\hline Bilateral & 889 & 743 & 926 & 1,181 & 1,019 & 1,630 \\
\hline Multilateral & 672 & 469 & 682 & 835 & 824 & 1,080 \\
\hline Total government debt & 7,507 & 7,924 & 10,213 & 12,559 & 12,533 & 13,638 \\
\hline Government-guaranteed debt & 3,310 & 3,226 & 3,203 & 2,438 & 3,505 & 3,768 \\
\hline Domestic & 829 & 1,005 & 1,135 & 1,341 & 1,495 & 1,761 \\
\hline Foreign & 2,481 & 2,222 & 2,067 & 1,097 & 2,010 & 2,007 \\
\hline Government and government-guaranteed debt & 10,817 & 11,151 & 13,416 & 14,996 & 16,038 & 17,406 \\
\hline & \multicolumn{6}{|c|}{ (Percent of GDP) } \\
\hline Government debt & 25.9 & 23.9 & 29.6 & 33.7 & 30.2 & 28.2 \\
\hline Domestic & 20.5 & 20.3 & 24.9 & 28.3 & 25.7 & 22.6 \\
\hline Foreign & 5.4 & 3.7 & 4.7 & 5.4 & 4.4 & 5.6 \\
\hline Government-guaranteed debt & 11.4 & 9.7 & 9.3 & 6.5 & 8.4 & 7.8 \\
\hline Government and government-guaranteed debt & 37.3 & 33.6 & 38.9 & 40.2 & 38.6 & 36.1 \\
\hline \multicolumn{7}{|l|}{ Memorandum item: } \\
\hline GDP at current market prices & 28,992 & 33,142 & 34,506 & 37,300 & 41,526 & 48,280 \\
\hline
\end{tabular}

Sources: Namibian authorities; and IMF staff estimates.

1/ Fiscal year begins April 1. Unless otherwise indicated, data correspond to debt stocks at the end of each fiscal year. 


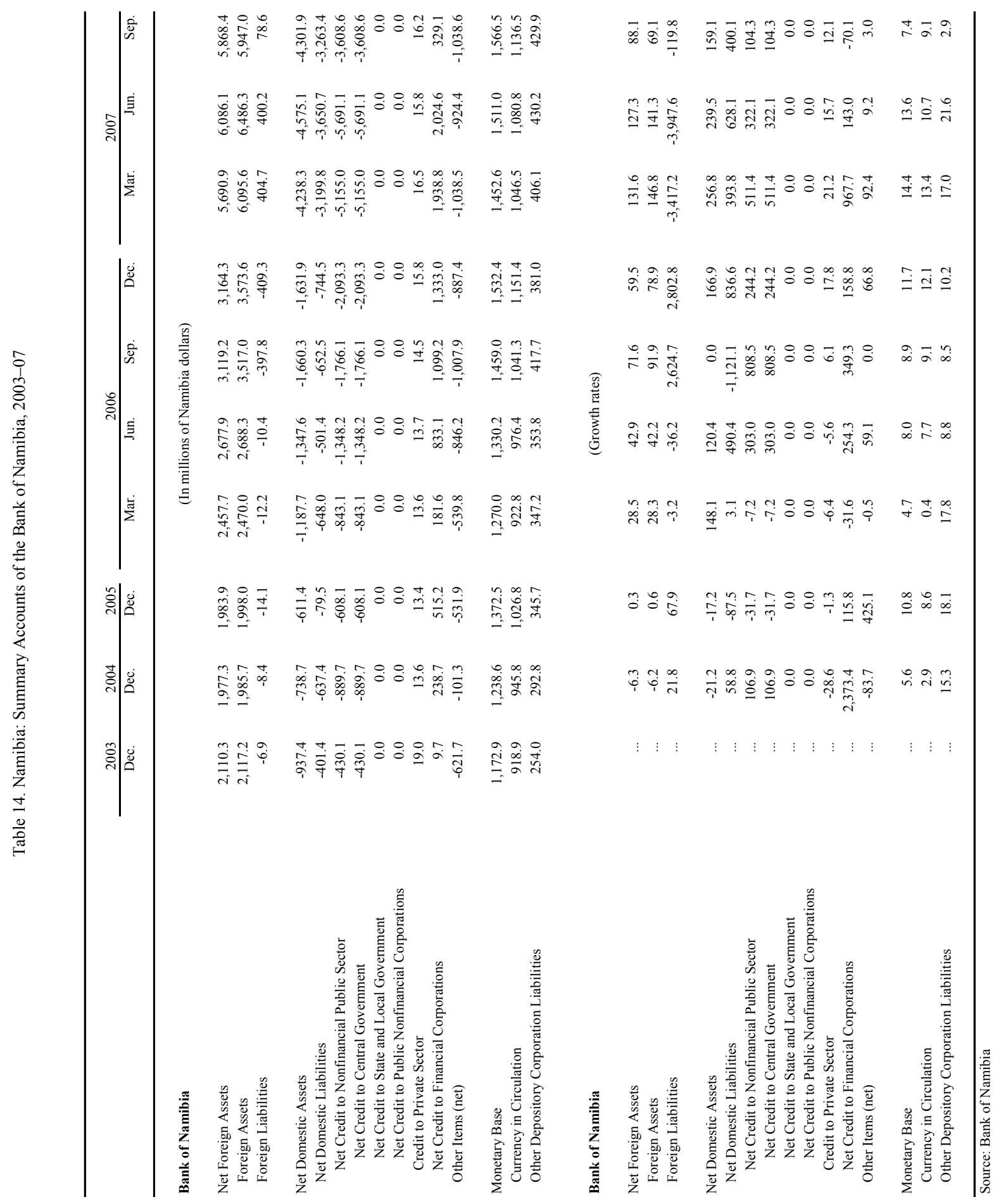


Table 15. Namibia: Monetary Survey, 2003-07

\begin{tabular}{|c|c|c|c|c|c|c|c|c|c|c|}
\hline \multirow[b]{3}{*}{ Monetary Survey } & \multirow{2}{*}{$\frac{2003}{\text { Dec. }}$} & \multirow{2}{*}{$\begin{array}{l}2004 \\
\text { Dec. }\end{array}$} & \multirow{2}{*}{$\frac{2005}{\text { Dec. }}$} & \multicolumn{4}{|c|}{2006} & \multicolumn{3}{|c|}{2007} \\
\hline & & & & Mar. & Jun. & Sep. & Dec. & Mar. & Jun. & Sep \\
\hline & \multicolumn{10}{|c|}{ (In millions of Namibia dollars) } \\
\hline Net Foreign Assets & $1,259.6$ & 970.3 & -156.3 & 723.3 & $1,496.2$ & $3,944.3$ & $4,844.5$ & $6,898.3$ & $6,959.6$ & $7,834.3$ \\
\hline Foreign Assets & $3,639.3$ & $3,294.5$ & $2,283.6$ & $3,384.6$ & $3,717.6$ & $5,312.4$ & $6,315.8$ & $8,303.5$ & $8,372.5$ & $8,811.8$ \\
\hline Foreign Liabilities & $-2,379.7$ & $-2,324.2$ & $-2,440.0$ & $-2,661.3$ & $-2,221.4$ & $-1,368.2$ & $-1,471.3$ & $-1,405.2$ & $-1,412.9$ & -977.5 \\
\hline Net Domestic Assets & $12,367.0$ & $14,858.6$ & $17,526.5$ & $18,030.9$ & $19,049.8$ & $17,567.6$ & $17,695.7$ & $15,691.2$ & $15,537.4$ & $17,866.8$ \\
\hline Net Domestic Credit & $17,346.6$ & $21,169.4$ & $25,670.1$ & $26,543.5$ & $27,672.3$ & $27,940.0$ & $28,397.5$ & $27,301.8$ & $27,782.2$ & $30,197.9$ \\
\hline Net Credit to Nonfinancial Public Sector & 670.3 & $1,239.0$ & $1,717.6$ & $1,510.1$ & $1,038.3$ & 418.9 & 341.5 & $-2,350.0$ & $-2,479.4$ & $-1,035.5$ \\
\hline Net Credit to Central Government & 506.7 & 871.7 & $1,405.7$ & $1,088.2$ & 608.4 & 183.6 & 113.3 & $-2,671.4$ & $-2,883.5$ & $-1,086.7$ \\
\hline Credit to Central Government & $1,702.1$ & $2,180.3$ & $2,586.1$ & $2,528.4$ & $2,661.9$ & $2,464.0$ & $2,767.3$ & $3,107.8$ & $3,279.2$ & $3,046.3$ \\
\hline Liabilities to Central Government & $-1,195.4$ & $-1,308.6$ & $-1,180.3$ & $-1,440.3$ & $-2,053.5$ & $-2,280.4$ & $-2,654.0$ & $5,779.3$ & $6,162.7$ & $4,133.0$ \\
\hline Net Credit to State and Local Government & 19.3 & 15.6 & 22.4 & 28.7 & 25.0 & 31.3 & 48.2 & 33.0 & 36.0 & 56.7 \\
\hline Net Credit to Public Nonfinancial Corporations & 144.3 & 351.7 & 289.5 & 393.2 & 404.9 & 204.0 & 180.0 & 288.5 & 368.1 & -5.5 \\
\hline Credit to the Private Sector & $16,676.3$ & $19,918.7$ & $23,922.4$ & $24,748.2$ & $25,803.0$ & $26,789.2$ & $27,436.6$ & $28,634.4$ & $29,193.9$ & $30,040.3$ \\
\hline Net Credit to Other Financial Corporations & 0.0 & 11.7 & 30.1 & 285.2 & 831.0 & 731.9 & 619.4 & $1,017.3$ & $1,067.7$ & $1,193.1$ \\
\hline Other Items (net) & $-4,979.5$ & $-6,310.8$ & $-8,143.6$ & $-8,512.6$ & $-8,622.5$ & $-10,372.4$ & $-10,701.8$ & $-11,610.6$ & $-12,244.8$ & $-12,331.1$ \\
\hline Broad Money (M2) & $13,626.7$ & $15,828.9$ & $17,370.2$ & $18,754.2$ & $20,546.0$ & $21,511.9$ & $22,540.2$ & $22,589.5$ & $22,497.0$ & $25,701.1$ \\
\hline Narrow Money (M1) & $8,080.8$ & $9,569.8$ & $9,408.8$ & $11,433.9$ & $12,090.5$ & $12,850.8$ & $13,701.1$ & $14,826.9$ & $13,361.4$ & $15,235.3$ \\
\hline Currency in Circulation & 584.6 & 632.7 & 680.0 & 681.0 & 726.7 & 785.6 & 763.4 & 797.4 & 814.5 & 861.8 \\
\hline Demand Deposits & $7,496.1$ & $8,937.1$ & $8,728.8$ & $10,752.9$ & $11,363.8$ & $12,065.2$ & $12,937.7$ & $14,029.4$ & $12,546.9$ & $14,373.4$ \\
\hline Other Deposits & $5,545.9$ & $6,259.1$ & $7,961.4$ & $7,308.9$ & $8,446.0$ & $8,655.2$ & $8,833.3$ & $7,756.7$ & $9,129.7$ & $10,459.9$ \\
\hline Monetary Survey & \multicolumn{10}{|c|}{ (Growth rates) } \\
\hline Net Foreign Assets & $\ldots$ & -23.0 & -116.1 & -54.1 & $1,478.3$ & $-6,040.2$ & $-3,199.5$ & 853.7 & 365.1 & 98.6 \\
\hline Foreign Assets & $\ldots$ & -9.5 & -30.7 & 5.1 & 57.7 & 150.0 & 176.6 & 145.3 & 125.2 & 65.9 \\
\hline Foreign Liabilities & $\ldots$ & -2.3 & 5.0 & 61.8 & -1.8 & -37.6 & -39.7 & -47.2 & -36.4 & -28.6 \\
\hline Net Domestic Assets & $\ldots$ & 20.1 & 18.0 & 20.9 & 11.4 & 2.5 & 1.0 & -13.0 & -18.4 & 1.7 \\
\hline Net Domestic Credit & $\ldots$ & 22.0 & 21.3 & 20.5 & 17.7 & 14.4 & 10.6 & 2.9 & 0.4 & 8.1 \\
\hline Net Credit to Nonfinancial Public Sector & $\ldots$ & 84.9 & 38.6 & 28.2 & -41.4 & -73.6 & -80.1 & -255.6 & -338.8 & -347.2 \\
\hline Net Credit to Central Government & $\ldots$ & 72.0 & 61.3 & 33.6 & -56.4 & -86.2 & -91.9 & -345.5 & -573.9 & -691.9 \\
\hline Credit to Central Government & $\ldots$ & 28.1 & 18.6 & 16.8 & 20.8 & 18.3 & 7.0 & 22.9 & 23.2 & 23.6 \\
\hline Liabilities to Central Government & $\ldots$ & 9.5 & -9.8 & 6.7 & 154.3 & 204.7 & 124.9 & -501.3 & -400.1 & -281.2 \\
\hline Net Credit to State and Local Government & $\ldots$ & -19.3 & 43.6 & 245.8 & 204.9 & 138.9 & 115.2 & 15.0 & 44.1 & 81.3 \\
\hline Net Credit to Public Nonfinancial Corporations & $\ldots$ & 143.8 & -17.7 & 10.5 & 10.3 & -14.5 & -37.8 & -26.6 & -9.1 & -102.7 \\
\hline Credit to the Private Sector & $\ldots$ & 19.4 & 20.1 & 19.0 & 19.0 & 17.4 & 14.7 & 15.7 & 13.1 & 12.1 \\
\hline Net Credit to Other Financial Corporations & $\ldots$ & $\ldots$ & 157.3 & 397.7 & $1,301.3$ & $3,320.1$ & $1,957.8$ & 256.7 & 28.5 & 63.0 \\
\hline Other Items (net) & $\ldots$ & 26.7 & 29.0 & 19.5 & 34.4 & 42.2 & 31.4 & 36.4 & 42.0 & 18.9 \\
\hline Broad Money (M2) & $\ldots$ & 16.2 & 9.7 & 13.7 & 19.5 & 26.1 & 29.8 & 20.5 & 9.5 & 19.5 \\
\hline Narrow Money (M1) & $\ldots$ & 18.4 & -1.7 & 25.8 & 24.3 & 32.8 & 45.6 & 29.7 & 10.5 & 18.6 \\
\hline Currency in Circulation & $\ldots$ & 8.2 & 7.5 & 8.3 & 10.7 & 12.6 & 12.3 & 17.1 & 12.1 & 9.7 \\
\hline Demand Deposits & $\ldots$ & 19.2 & -2.3 & 27.1 & 25.3 & 34.4 & 48.2 & 30.5 & 10.4 & 19.1 \\
\hline Other Deposits & $\ldots$ & 12.9 & 27.2 & -1.2 & 13.1 & 17.1 & 11.0 & 6.1 & 8.1 & 20.9 \\
\hline
\end{tabular}

Source: Bank of Namibia. 
Table 16. Namibia: Interest Rates, 2001-07

\begin{tabular}{|c|c|c|c|c|c|c|c|}
\hline & 2001 & 2002 & 2003 & 2004 & 2005 & 2006 & $\begin{array}{r}2007 \\
\text { Oct. }\end{array}$ \\
\hline Short-term interest rates & \multicolumn{7}{|c|}{ (Annual averages in percent) } \\
\hline \multicolumn{8}{|l|}{ Bank rate (end of period) } \\
\hline In South Africa 1/ & 9.50 & 13.50 & 8.00 & 7.50 & 7.00 & 9.00 & 10.50 \\
\hline In Namibia & 9.25 & 12.75 & 7.75 & 7.50 & 7.00 & 9.00 & 10.50 \\
\hline \multicolumn{8}{|l|}{ Money market rate } \\
\hline In South Africa & 8.49 & 11.11 & 10.93 & 7.15 & 6.62 & 7.19 & 9.92 \\
\hline In Namibia & 9.53 & 10.46 & 10.03 & 6.93 & 6.93 & 7.12 & 8.97 \\
\hline \multicolumn{8}{|l|}{ Treasury bill rate $2 /$} \\
\hline In South Africa & 9.68 & 11.16 & 10.67 & 7.53 & 6.91 & 7.34 & 9.77 \\
\hline In Namibia & 9.29 & 11.00 & 10.51 & 7.78 & 7.09 & 7.26 & 9.16 \\
\hline \multicolumn{8}{|l|}{ Commercial bank deposit rate 3 / } \\
\hline In South Africa & 9.37 & 10.77 & 9.76 & 6.55 & 6.04 & 7.14 & 9.84 \\
\hline In Namibia & 6.79 & 7.81 & 8.76 & 6.35 & 6.24 & 6.30 & 7.95 \\
\hline \multicolumn{8}{|l|}{ Commercial bank lending rate $4 /$} \\
\hline In South Africa & 13.77 & 15.75 & 14.96 & 11.29 & 10.63 & 11.17 & 14.00 \\
\hline In Namibia & 14.53 & 13.84 & 14.70 & 11.39 & 10.61 & 11.18 & 13.56 \\
\hline \multicolumn{8}{|l|}{ Long-term interest rate } \\
\hline Government bond yield in South Africa & 11.41 & 11.50 & 9.62 & 9.53 & 8.07 & 7.94 & 8.12 \\
\hline Government bond yield in Namibia & 11.39 & 12.86 & 12.72 & 11.88 & 10.52 & 9.49 & 8.92 \\
\hline \multicolumn{8}{|l|}{ Memorandum items: } \\
\hline \multicolumn{8}{|l|}{ Consumer price inflation } \\
\hline In South Africa 5/ & 5.7 & 9.2 & 5.9 & 1.4 & 3.4 & 4.6 & 6.8 \\
\hline In Namibia 5/ & 9.5 & 11.3 & 7.2 & 4.1 & 2.3 & 5.1 & 6.7 \\
\hline \multicolumn{8}{|l|}{ Real interest rates $6 /$} \\
\hline \multicolumn{8}{|l|}{ Commercial bank deposits } \\
\hline In South Africa & 3.47 & 1.47 & 3.69 & 5.10 & 2.56 & 2.39 & 2.88 \\
\hline In Namibia & -2.51 & -3.18 & 1.50 & 2.12 & 3.89 & 1.19 & 1.20 \\
\hline \multicolumn{8}{|l|}{ Commercial bank lending } \\
\hline In South Africa & 7.63 & 6.03 & 8.60 & 9.77 & 6.99 & 6.24 & 6.77 \\
\hline In Namibia & 4.56 & 2.24 & 7.04 & 6.95 & 8.16 & 5.83 & 6.45 \\
\hline \multicolumn{8}{|l|}{ Government bond yield } \\
\hline In South Africa & 5.40 & 2.14 & 3.55 & 8.03 & 4.51 & 3.15 & 1.26 \\
\hline In Namibia & 1.69 & 1.36 & 5.19 & 7.43 & 8.07 & 4.22 & 2.10 \\
\hline
\end{tabular}

Sources: South African Reserve Bank; Bank of Namibia; and IMF, International Financial Statistics .

1/ South African Reserve Bank's repo rate.

2/ Average tender rate for 91-day bills.

3/ For South Africa, rates are upper margin of interest on time deposits of 88-91 days. For Namibia, rates are weighted averages of demand deposits, 88-day notice deposits, savings deposits, and deposits with a maturity of more than one year of two largest commercial banks.

4/ For South Africa, prime overdraft rate of major banks. For Namibia, weighted average of different lending instruments.

5/ Headline inflation for South Africa; Windhoek consumer price index for Namibia until 2004, NCPI from 2005 on.

6/ Deflated by consumer price indices. 


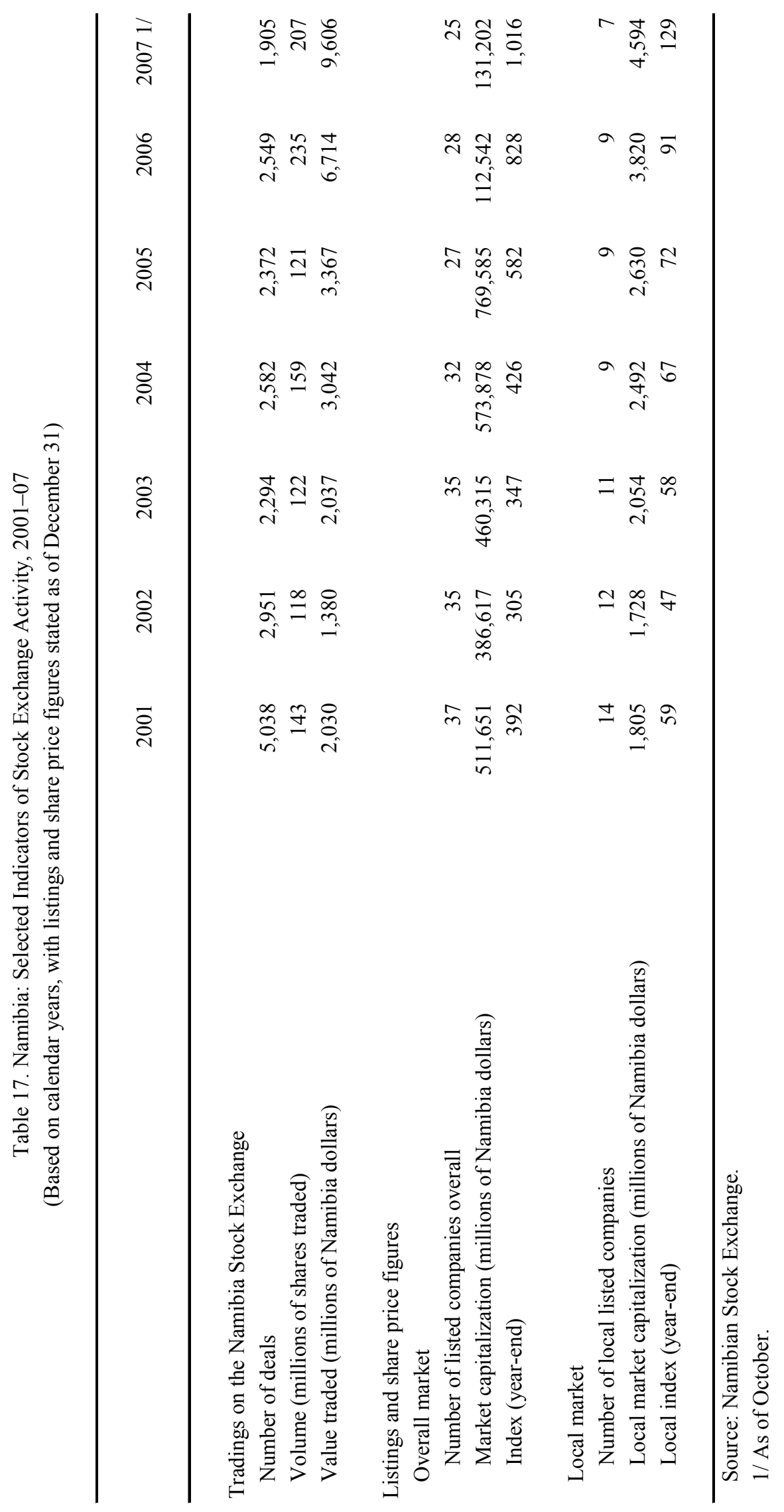


Table 18. Namibia: Balance of Payments, 2001-06

\begin{tabular}{|c|c|c|c|c|c|c|}
\hline & 2001 & 2002 & 2003 & 2004 & 2005 & 2006 \\
\hline & \multicolumn{6}{|c|}{ (In millions of U.S. dollars) } \\
\hline Current account & 59.7 & 115.0 & 299.9 & 461.7 & 344.4 & $1,106.1$ \\
\hline Trade balance & -198.9 & -207.6 & -460.2 & -283.6 & -265.3 & 94.8 \\
\hline Exports, f.o.b. & $1,142.4$ & $1,072.4$ & $1,250.9$ & $1,823.4$ & $2,066.7$ & $2,652.3$ \\
\hline Of which: diamonds & 524.1 & 533.3 & 510.9 & 824.5 & 848.3 & $1,083.8$ \\
\hline other minerals & 194.4 & 200.3 & 182.6 & 227.5 & 275.0 & 474.7 \\
\hline fish & 157.4 & 149.8 & 229.5 & 178.7 & 155.9 & 204.8 \\
\hline Imports, f.o.b. & $-1,341.3$ & $-1,280.0$ & $-1,711.1$ & $-2,107.0$ & $-2,331.9$ & $-2,557.5$ \\
\hline Services & 16.5 & 37.1 & 138.6 & 54.9 & 43.1 & 97.2 \\
\hline Transportation (net) & -45.3 & -38.1 & -6.6 & -109.9 & -107.8 & -48.5 \\
\hline Travel & 163.3 & 152.5 & 230.0 & 281.4 & 239.7 & 265.3 \\
\hline Other services & -101.5 & -77.2 & -84.7 & -116.6 & -88.8 & -119.8 \\
\hline Income & -104.6 & 10.1 & 163.2 & 23.1 & -103.1 & -35.8 \\
\hline Compensation of employees & -0.9 & -1.3 & -4.1 & -4.2 & -3.6 & -5.9 \\
\hline Investment income & -103.6 & 11.5 & 167.3 & 27.3 & -99.5 & -29.9 \\
\hline Current transfers & 346.7 & 275.3 & 458.3 & 667.3 & 669.7 & 949.9 \\
\hline Government (net) & 333.7 & 264.5 & 437.3 & 644.8 & 649.0 & 927.1 \\
\hline Of which: SACU receipts $1 /$ & 313.9 & 248.0 & 386.8 & 606.8 & 650.1 & 893.9 \\
\hline Capital and financial account & 137.6 & -213.0 & -281.9 & -604.7 & -451.9 & $-1,236.8$ \\
\hline Capital account & 94.8 & 40.8 & 67.3 & 77.2 & 79.4 & 84.7 \\
\hline Financial account & 42.8 & -253.8 & -349.2 & -681.9 & -531.3 & $-1,321.5$ \\
\hline Direct investment & 378.1 & 187.3 & 159.1 & 248.4 & 360.4 & 339.1 \\
\hline Portfolio investment & -420.5 & -422.3 & -633.5 & -842.6 & $-1,043.7$ & $-1,112.4$ \\
\hline Other investment & 43.3 & 97.2 & 108.9 & -54.3 & 114.4 & -407.9 \\
\hline Reserve assets (increase -) & 41.9 & -115.9 & 16.2 & -33.4 & 37.5 & -140.3 \\
\hline Net errors and omissions & -197.3 & 98.0 & -18.0 & 143.0 & 107.5 & 130.7 \\
\hline \multicolumn{7}{|l|}{ Memorandum items: } \\
\hline Current account (excluding official transfers) & -274.0 & -149.5 & -137.3 & -183.1 & -304.6 & 179.0 \\
\hline \multicolumn{7}{|l|}{ Current account/GDP (in percent) } \\
\hline Excluding current official transfers & -8.5 & -4.8 & -3.1 & -3.2 & -4.9 & 2.6 \\
\hline Including current official transfers & 1.9 & 3.7 & 6.7 & 8.2 & 5.5 & 15.9 \\
\hline International reserves (end-of-period) 2/ & 224.0 & 336.2 & 318.9 & 352.7 & 315.9 & 512.7 \\
\hline In months of imports of goods and services & 1.7 & 2.7 & 1.9 & 1.7 & 1.4 & 2.1 \\
\hline \multicolumn{7}{|l|}{ Exchange rates } \\
\hline Namibia dollars per U.S. dollar (period average) & 8.60 & 10.52 & 7.56 & 6.45 & 6.36 & 6.77 \\
\hline Namibia dollars per U.S. dollar (end-of-period) & 12.13 & 8.64 & 6.64 & 5.63 & 6.33 & 6.97 \\
\hline US\$ per Namibia dollars (period average) & 0.12 & 0.10 & 0.13 & 0.16 & 0.16 & 0.15 \\
\hline US\$ per Namibia dollars (end-of-period) & 0.08 & 0.12 & 0.15 & 0.18 & 0.16 & 0.14 \\
\hline
\end{tabular}

Sources: Bank of Namibia and IMF staff estimates.

1/ Southern African Customs Union.

2/ Gross foreign assets of the Bank of Namibia. 
Table 19. Namibia: Merchandise Exports by Commodity Group, 2001-First Half of 2007

\begin{tabular}{|c|c|c|c|c|c|c|c|}
\hline & 2001 & 2002 & 2003 & 2004 & 2005 & 2006 & $\begin{array}{r}2007 \\
\text { First Half } \\
\end{array}$ \\
\hline & \multicolumn{4}{|c|}{ (US\$ Millions) } & & & \\
\hline Exports, f.o.b. & $1,142.4$ & $1,072.4$ & $1,250.9$ & $1,823.4$ & $2,066.7$ & $2,652.3$ & $1,341.3$ \\
\hline Diamonds & 524.1 & 533.3 & 510.9 & 824.5 & 848.3 & $1,083.8$ & 469.9 \\
\hline Other minerals & 194.4 & 200.3 & 182.6 & 227.5 & 275.0 & 474.7 & 338.6 \\
\hline Fish & 157.4 & 149.8 & 229.5 & 178.7 & 155.9 & 204.8 & 146.0 \\
\hline Unproceesed fish, lobster \& crab & 41.0 & 38.0 & 27.9 & 44.8 & 50.9 & 54.2 & 19.0 \\
\hline Processed fish & 116.5 & 111.8 & 201.6 & 133.9 & 105.0 & 150.6 & 127.0 \\
\hline Other manufactured products & 124.3 & 66.3 & 156.5 & 308.5 & 403.3 & 559.4 & 248.1 \\
\hline Food and live animals & 121.8 & 117.3 & 161.3 & 194.4 & 265.5 & 269.7 & 132.9 \\
\hline Meat \& meat preparations & 73.0 & 53.2 & 78.2 & 99.7 & 147.5 & 144.7 & 68.3 \\
\hline Other commodities & 1.5 & 1.6 & 2.8 & 4.5 & 4.6 & 4.3 & 2.0 \\
\hline \multirow[t]{2}{*}{ Other exports } & 18.9 & 3.9 & 7.4 & 85.3 & 114.0 & 55.7 & 3.7 \\
\hline & \multicolumn{4}{|c|}{ (Growth rates) } & & & \\
\hline Exports, f.o.b. & -13.4 & -6.1 & 16.6 & 45.8 & 13.3 & 28.3 & $\ldots$ \\
\hline Diamonds & -14.5 & 1.8 & -4.2 & 61.4 & 2.9 & 27.8 & $\ldots$ \\
\hline Other minerals & 5.5 & 3.0 & -8.8 & 24.6 & 20.8 & 72.6 & $\ldots$ \\
\hline Fish & -14.8 & -4.9 & 53.2 & -22.1 & -12.7 & 31.3 & $\ldots$ \\
\hline Unproceesed fish, lobster \& crab & 32.2 & -7.2 & -26.7 & 60.7 & 13.6 & 6.5 & $\ldots$ \\
\hline Processed fish & -24.3 & -4.0 & 80.4 & -33.6 & -21.5 & 43.4 & $\ldots$ \\
\hline Other manufactured products & -0.3 & -46.7 & 136.1 & 97.2 & 30.7 & 38.7 & $\ldots$ \\
\hline Food and live animals & -0.5 & -3.7 & 37.6 & 20.5 & 36.6 & 1.6 & $\ldots$ \\
\hline Meat \& meat preparations & -31.7 & -27.2 & 47.1 & 27.4 & 48.0 & -1.9 & $\ldots$ \\
\hline Other commodities & -28.1 & 6.6 & 71.4 & 61.5 & 1.4 & -6.0 & $\ldots$ \\
\hline \multirow[t]{2}{*}{ Other exports } & -45.5 & -79.5 & 90.8 & $1,052.6$ & 33.7 & -51.1 & $\ldots$ \\
\hline & \multicolumn{4}{|c|}{ (Percent of Total) } & & & \\
\hline Exports, f.o.b. & 100.0 & 100.0 & 100.0 & 100.0 & 100.0 & 100.0 & 100.0 \\
\hline Diamonds & 45.9 & 49.7 & 40.8 & 45.2 & 41.0 & 40.9 & 35.0 \\
\hline Other minerals & 17.0 & 18.7 & 14.6 & 12.5 & 13.3 & 17.9 & 25.2 \\
\hline Fish & 13.8 & 14.0 & 18.3 & 9.8 & 7.5 & 7.7 & 10.9 \\
\hline Unproceesed fish, lobster \& crab & 3.6 & 3.5 & 2.2 & 2.5 & 2.5 & 2.0 & 1.4 \\
\hline Processed fish & 10.2 & 10.4 & 16.1 & 7.3 & 5.1 & 5.7 & 9.5 \\
\hline Other manufactured products & 10.9 & 6.2 & 12.5 & 16.9 & 19.5 & 21.1 & 18.5 \\
\hline Food and live animals & 10.7 & 10.9 & 12.9 & 10.7 & 12.8 & 10.2 & 9.9 \\
\hline Meat \& meat preparations & 6.4 & 5.0 & 6.3 & 5.5 & 7.1 & 5.5 & 5.1 \\
\hline Other commodities & 0.1 & 0.2 & 0.2 & 0.2 & 0.2 & 0.2 & 0.2 \\
\hline Other exports & 1.7 & 0.4 & 0.6 & 4.7 & 5.5 & 2.1 & 0.3 \\
\hline
\end{tabular}

Source: Bank of Namibia. 
Table 20. Namibia: Mineral Exports, 2001-First Half of 2007

\begin{tabular}{|c|c|c|c|c|c|c|c|}
\hline & 2001 & 2002 & 2003 & 2004 & 2005 & 2006 & $\begin{array}{r}2007 \\
\text { First Half }\end{array}$ \\
\hline \multicolumn{8}{|l|}{ N\$ Millions } \\
\hline Diamonds & $4,508.9$ & $5,608.3$ & $3,864.6$ & $5,317.9$ & $5,397.3$ & $7,334.1$ & $3,366.8$ \\
\hline Uranium & 998.5 & $1,206.5$ & 592.2 & 750.3 & 926.3 & $1,554.8$ & $1,535.1$ \\
\hline Zinc & 134.6 & 140.2 & 197.8 & 211.0 & 279.0 & 764.3 & 386.9 \\
\hline Gold & 207.7 & 301.0 & 219.7 & 158.9 & 228.0 & 358.6 & 227.2 \\
\hline Copper & 200.7 & 261.4 & 184.1 & 212.9 & 194.3 & 312.8 & 154.3 \\
\hline Silver & 24.8 & 63.1 & 28.3 & 31.0 & 35.7 & 88.1 & 28.0 \\
\hline Lead & 31.1 & 48.0 & 56.4 & 45.9 & 34.2 & 75.1 & 30.6 \\
\hline Other & 75.1 & 86.3 & 102.6 & 57.4 & 51.9 & 58.3 & 64.3 \\
\hline TOTAL & $6,181.4$ & $7,714.8$ & $5,245.9$ & $6,785.5$ & $7,146.8$ & $10,546.2$ & $5,793.1$ \\
\hline Official exchange rate (average) & 8.60 & 10.52 & 7.56 & 6.45 & 6.36 & 6.77 & 7.17 \\
\hline \multicolumn{8}{|l|}{ US\$ Millions } \\
\hline Diamonds & 524.1 & 533.3 & 510.9 & 824.5 & 848.3 & $1,083.8$ & 469.9 \\
\hline Uranium & 116.1 & 114.7 & 78.3 & 116.3 & 145.6 & 229.8 & 214.3 \\
\hline Zinc & 15.6 & 13.3 & 26.2 & 32.7 & 43.9 & 112.9 & 54.0 \\
\hline Gold & 24.1 & 28.6 & 29.0 & 24.6 & 35.8 & 53.0 & 31.7 \\
\hline Copper & 23.3 & 24.9 & 24.3 & 33.0 & 30.5 & 46.2 & 21.5 \\
\hline Silver & 2.9 & 6.0 & 3.7 & 4.8 & 5.6 & 13.0 & 3.9 \\
\hline Lead & 3.6 & 4.6 & 7.5 & 7.1 & 5.4 & 11.1 & 4.3 \\
\hline Other & 8.7 & 8.2 & 13.6 & 8.9 & 8.2 & 8.6 & 9.0 \\
\hline TOTAL & 718.5 & 733.6 & 693.5 & $1,052.0$ & $1,123.3$ & $1,558.4$ & 808.5 \\
\hline
\end{tabular}

Source: Bank of Namibia. 
Table 21. Namibia: External Trade Indices, 2001-06

\begin{tabular}{|c|c|c|c|c|c|c|}
\hline & 2001 & 2002 & 2003 & 2004 & 2005 & 2006 \\
\hline & \multicolumn{6}{|c|}{ (In U.S. dollar terms, $2001=100$ ) } \\
\hline \multicolumn{7}{|l|}{ Exports } \\
\hline Value & 100.0 & 93.9 & 109.5 & 159.6 & 180.9 & 232.3 \\
\hline Volume & 100.0 & 89.8 & 99.9 & 130.6 & 136.6 & 153.1 \\
\hline Price & 100.0 & 104.6 & 109.6 & 122.2 & 132.4 & 151.7 \\
\hline \multicolumn{7}{|l|}{ Imports } \\
\hline Value & 100.0 & 95.4 & 127.6 & 157.1 & 173.9 & 190.7 \\
\hline Volume & 100.0 & 91.7 & 117.1 & 140.3 & 150.3 & 159.7 \\
\hline Price & 100.0 & 104.1 & 108.9 & 112.0 & 115.7 & 119.4 \\
\hline \multirow[t]{2}{*}{ Terms of trade } & 100.0 & 100.5 & 100.6 & 109.1 & 114.4 & 127.1 \\
\hline & \multicolumn{6}{|c|}{ (Annual change in percent) } \\
\hline \multicolumn{7}{|l|}{ Exports } \\
\hline Value & 15.6 & -6.1 & 16.6 & 45.8 & 13.3 & 28.4 \\
\hline Volume & -17.6 & -10.2 & 11.3 & 30.7 & 4.6 & 12.1 \\
\hline Price & 5.0 & 4.6 & 4.9 & 11.5 & 8.3 & 14.6 \\
\hline \multicolumn{7}{|l|}{ Imports } \\
\hline Value & 2.3 & -4.6 & 33.7 & 23.1 & 10.7 & 9.7 \\
\hline Volume & -2.2 & -8.3 & 27.7 & 19.8 & 7.1 & 6.3 \\
\hline Price & 50.8 & 4.1 & 4.7 & 2.8 & 3.3 & 3.2 \\
\hline Terms of trade & 0.5 & 0.5 & 0.2 & 8.5 & 4.8 & 11.1 \\
\hline
\end{tabular}

Sources: Bank of Namibia; and IMF staff estimates. 
Table 22. Namibia: Merchandise Imports by Commodity Group, 2001-06

\begin{tabular}{|c|c|c|c|c|c|c|}
\hline & 2001 & 2002 & 2003 & 2004 & 2005 & 2006 \\
\hline & & & & & & Preliminary \\
\hline & \multicolumn{6}{|c|}{ (US\$ Millions) } \\
\hline Total imports, c.i.f. & $1,421.3$ & $1,397.8$ & $2,334.2$ & $2,407.6$ & $2,524.8$ & $2,815.9$ \\
\hline Food, live animals, beverages, and tobacco & 22.3 & 18.2 & 61.3 & 85.2 & 92.7 & 80.8 \\
\hline Textiles, clothing, footwear & 25.2 & 24.5 & 44.2 & 43.0 & 47.6 & 56.1 \\
\hline Wood, paper and paper products, furniture & 84.8 & 67.2 & 123.8 & 128.2 & 140.3 & 136.9 \\
\hline Mineral fuels and lubricants & 170.0 & 169.8 & 256.3 & 171.2 & 188.0 & 192.9 \\
\hline Chemicals, plastic, medical, rubber & 62.9 & 67.1 & 99.5 & 105.8 & 116.0 & 126.4 \\
\hline Metal and metal products & 4.2 & 6.5 & 7.1 & 12.7 & 25.5 & 23.1 \\
\hline Machinery and electrical goods & 281.8 & 276.4 & 452.4 & 465.4 & 468.6 & 576.9 \\
\hline Vehicles and transport equipment & 168.2 & 142.0 & 264.0 & 351.8 & 388.2 & 423.6 \\
\hline \multirow[t]{2}{*}{ All other imports } & 601.8 & 626.1 & $1,025.5$ & $1,044.2$ & $1,057.8$ & $1,199.1$ \\
\hline & \multicolumn{6}{|c|}{ (Growth rates) } \\
\hline Total imports, c.i.f. & & -1.7 & 67.0 & 3.1 & 4.9 & 11.5 \\
\hline Food, live animals, beverages, and tobacco & & -18.5 & 237.1 & 39.0 & 8.7 & -12.8 \\
\hline Textiles, clothing, footwear & & -2.8 & 80.0 & -2.7 & 10.8 & 17.7 \\
\hline Wood, paper and paper products, furniture & & -20.8 & 84.2 & 3.6 & 9.4 & -2.5 \\
\hline Mineral fuels and lubricants & & -0.1 & 51.0 & -33.2 & 9.8 & 2.6 \\
\hline Chemicals, plastic, medical, rubber & & 6.8 & 48.3 & 6.3 & 9.6 & 8.9 \\
\hline Metal and metal products & & 52.4 & 9.8 & 78.2 & 101.6 & -9.3 \\
\hline Machinery and electrical goods & & -1.9 & 63.7 & 2.9 & 0.7 & 23.1 \\
\hline Vehicles and transport equipment & & -15.6 & 85.9 & 33.3 & 10.3 & 9.1 \\
\hline All other imports & & 4.0 & 63.8 & 1.8 & 1.3 & 13.4 \\
\hline \multicolumn{7}{|l|}{ Memorandum items: } \\
\hline Total imports, f.o.b. (in millions of U.S. dollars) & $1,341.3$ & $1,280.0$ & $1,711.1$ & $2,107.0$ & $2,331.9$ & $2,557.5$ \\
\hline Imports, f.o.b./ imports, c.i.f. (in percent) & 94.4 & 91.6 & 73.3 & 87.5 & 92.4 & 90.8 \\
\hline
\end{tabular}

Source: Bank of Namibia, and IMF staff estimates. 
Table 23. Namibia: Imports (c.i.f) by Country of Origin, 2001-06

\begin{tabular}{|c|c|c|c|c|c|c|}
\hline & 2001 & 2002 & 2003 & 2004 & 2005 & 2006 \\
\hline & \multicolumn{6}{|c|}{ (In millions of Namibia dollars) } \\
\hline Belgium & 43.1 & 88.1 & 77.5 & 61.2 & 103.1 & 68.7 \\
\hline Canada & $\ldots$ & 121.4 & 5.6 & 5.9 & 9.7 & 23.9 \\
\hline China & 141.4 & 121.4 & 194.6 & 182.1 & 255.6 & 659.4 \\
\hline France & 71.2 & 150.3 & 93.7 & 29.8 & 33.3 & 62.5 \\
\hline Germany & 253.8 & 426.7 & 375.6 & 284.8 & 307.7 & 425.1 \\
\hline India & 29.1 & 48.6 & 74.2 & 137.4 & 83.3 & 139.6 \\
\hline Isreal & 24.0 & $\ldots$ & 91.5 & 4.7 & 7.8 & 16.6 \\
\hline Japan & 23.7 & $\ldots$ & 94.7 & 55.9 & 30.8 & 44.1 \\
\hline Netherlands & 49.9 & 46.9 & 43.8 & 33.0 & 80.6 & 56.2 \\
\hline New Zealand & $\ldots$ & $\ldots$ & 0.5 & 1.0 & 0.1 & 0.9 \\
\hline Russian Federation & $\ldots$ & $\ldots$ & 17.2 & 9.2 & 8.6 & 16.5 \\
\hline Singapore & $\ldots$ & 141.9 & 94.0 & 48.8 & 39.8 & 52.1 \\
\hline South Africa & $10,736.0$ & $10,507.7$ & $14,573.4$ & $13,239.3$ & $13,364.3$ & $15,698.5$ \\
\hline Spain & 108.4 & 169.4 & 258.5 & 102.1 & 227.6 & 135.1 \\
\hline Switzerland & 253.8 & 169.4 & 88.9 & 69.4 & 131.8 & 160.6 \\
\hline United Kingdom & 152.0 & 357.7 & 211.9 & 400.1 & 172.1 & 160.7 \\
\hline United States of America & 117.0 & 272.5 & 149.3 & 115.8 & 125.2 & 283.1 \\
\hline Zimbabwe & 46.0 & $\ldots$ & 235.1 & 120.9 & 130.6 & 126.4 \\
\hline Sub-total & $12,049.3$ & $12,622.1$ & $16,680.1$ & $14,901.2$ & $15,112.0$ & $18,129.9$ \\
\hline Other & 493.3 & 964.2 & $1,203.8$ & 627.6 & 951.1 & 925.6 \\
\hline \multirow[t]{2}{*}{ Total } & $12,542.6$ & $13,586.3$ & $17,883.9$ & $15,528.8$ & $16,063.1$ & $19,055.6$ \\
\hline & \multicolumn{6}{|c|}{ (In percent of total) } \\
\hline Belgium & 0.3 & 0.6 & 0.4 & 0.4 & 0.6 & 0.4 \\
\hline Canada & $\ldots$ & 0.9 & 0.0 & 0.0 & 0.1 & 0.1 \\
\hline China & 1.1 & 0.9 & 1.1 & 1.2 & 1.6 & 3.5 \\
\hline France & 0.6 & 1.1 & 0.5 & 0.2 & 0.2 & 0.3 \\
\hline Germany & 2.0 & 3.1 & 2.1 & 1.8 & 1.9 & 2.2 \\
\hline India & 0.2 & 0.4 & 0.4 & 0.9 & 0.5 & 0.7 \\
\hline Isreal & 0.2 & $\ldots$ & 0.5 & 0.0 & 0.0 & 0.1 \\
\hline Japan & 0.2 & $\ldots$ & 0.5 & 0.4 & 0.2 & 0.2 \\
\hline Netherlands & 0.4 & 0.3 & 0.2 & 0.2 & 0.5 & 0.3 \\
\hline New Zealand & $\ldots$ & $\ldots$ & 0.0 & 0.0 & 0.0 & 0.0 \\
\hline Russian Federation & $\ldots$ & $\ldots$ & 0.1 & 0.1 & 0.1 & 0.1 \\
\hline Singapore & $\ldots$ & 1.0 & 0.5 & 0.3 & 0.2 & 0.3 \\
\hline South Africa & 85.6 & 77.3 & 81.5 & 85.3 & 83.2 & 82.4 \\
\hline Spain & 0.9 & 1.2 & 1.4 & 0.7 & 1.4 & 0.7 \\
\hline Switzerland & 2.0 & 1.2 & 0.5 & 0.4 & 0.8 & 0.8 \\
\hline United Kingdom & 1.2 & 2.6 & 1.2 & 2.6 & 1.1 & 0.8 \\
\hline United States of America & 0.9 & 2.0 & 0.8 & 0.7 & 0.8 & 1.5 \\
\hline Zimbabwe & 0.4 & $\ldots$ & 1.3 & 0.8 & 0.8 & 0.7 \\
\hline Sub-total & 96.1 & 92.9 & 93.3 & 96.0 & 94.1 & 95.1 \\
\hline Other & 3.9 & 7.1 & 6.7 & 4.0 & 5.9 & 4.9 \\
\hline Total & 100.0 & 100.0 & 100.0 & 100.0 & 100.0 & 100.0 \\
\hline
\end{tabular}

Source: Central Bureau of Statistics. 
Table 24. Namibia: Exports by Country of Destination, 2001-06

\begin{tabular}{|c|c|c|c|c|c|c|}
\hline & 2001 & 2002 & 2003 & 2004 & 2005 & 2006 \\
\hline & \multicolumn{6}{|c|}{ (In millions of Namibia dollars) } \\
\hline Angola & 603.0 & $1,944.0$ & $3,152.2$ & $1,523.4$ & $1,145.3$ & $1,309.9$ \\
\hline Australia & $\ldots$ & 53.0 & 60.9 & 35.0 & 58.2 & 51.6 \\
\hline Belgium & 64.0 & 78.5 & 58.8 & 48.9 & 57.4 & 83.1 \\
\hline Botswana & 53.3 & 63.6 & 107.5 & 78.8 & 75.4 & 103.1 \\
\hline Canada & $\ldots$ & 42.5 & 136.6 & 346.4 & 511.4 & 866.7 \\
\hline China & 54.7 & $\ldots$ & 107.2 & 205.1 & 288.5 & 332.5 \\
\hline Congo & 41.8 & 95.1 & 355.1 & 66.0 & 74.0 & 310.7 \\
\hline France & 201.7 & 842.4 & 161.3 & $1,561.6$ & 94.6 & 275.7 \\
\hline Germany & 102.2 & 153.6 & 150.0 & 230.3 & 593.7 & 740.4 \\
\hline Ghana & $\ldots$ & 73.7 & 155.0 & 9.0 & 33.3 & 30.2 \\
\hline Iceland & $\ldots$ & 126.5 & 55.2 & 22.1 & 1.1 & 0.3 \\
\hline Italy & 204.6 & 243.1 & 309.6 & 266.0 & 395.4 & $1,654.1$ \\
\hline Japan & 79.1 & 178.9 & 108.7 & 106.5 & 171.5 & 285.4 \\
\hline Netherlands & 157.5 & 179.7 & 160.5 & 139.3 & 219.0 & 249.5 \\
\hline Russian Federation & $\ldots$ & $\ldots$ & 56.4 & 11.0 & 15.4 & 26.0 \\
\hline South Africa & $2,471.7$ & $3,396.8$ & $3,202.8$ & $4,055.5$ & $4,864.3$ & $5,668.5$ \\
\hline Spain & $1,538.1$ & $1,622.8$ & $2,035.8$ & $1,061.5$ & $1,150.2$ & $1,372.6$ \\
\hline Switzerland & $\ldots$ & 40.7 & 38.8 & 35.4 & 47.1 & 162.8 \\
\hline United Kingdom & $4,103.4$ & $3,281.7$ & $2,641.9$ & $3,407.3$ & $3,274.3$ & $5,877.7$ \\
\hline United States of America & 346.0 & 421.2 & 655.9 & $1,258.8$ & $1,454.5$ & 555.2 \\
\hline Zimbabwe & 36.4 & $\ldots$ & 27.6 & 22.8 & 35.3 & 33.4 \\
\hline Sub-total & $10,057.5$ & $12,837.9$ & $13,737.8$ & $14,490.7$ & $14,559.9$ & $19,989.4$ \\
\hline Other & 391.7 & 522.0 & 601.0 & $1,226.8$ & $1,388.6$ & $2,976.4$ \\
\hline \multirow[t]{2}{*}{ Total } & $10,449.2$ & $13,359.9$ & $14,338.8$ & $15,717.5$ & $15,948.5$ & $22,965.8$ \\
\hline & \multicolumn{6}{|c|}{ (In percent of total) } \\
\hline Angola & 5.8 & 14.6 & 22.0 & 9.7 & 7.2 & 5.7 \\
\hline Australia & $\ldots$ & 0.4 & 0.4 & 0.2 & 0.4 & 0.2 \\
\hline Belgium & 0.6 & 0.6 & 0.4 & 0.3 & 0.4 & 0.4 \\
\hline Botswana & 0.5 & 0.5 & 0.7 & 0.5 & 0.5 & 0.4 \\
\hline Canada & $\ldots$ & 0.3 & 1.0 & 2.2 & 3.2 & 3.8 \\
\hline China & 0.5 & $\ldots$ & 0.7 & 1.3 & 1.8 & 1.4 \\
\hline Congo & 0.4 & 0.7 & 2.5 & 0.4 & 0.5 & 1.4 \\
\hline France & 1.9 & 6.3 & 1.1 & 9.9 & 0.6 & 1.2 \\
\hline Germany & 1.0 & 1.1 & 1.0 & 1.5 & 3.7 & 3.2 \\
\hline Ghana & $\cdots$ & 0.6 & 1.1 & 0.1 & 0.2 & 0.1 \\
\hline Iceland & $\ldots$ & 0.9 & 0.4 & 0.1 & 0.0 & 0.0 \\
\hline Italy & 2.0 & 1.8 & 2.2 & 1.7 & 2.5 & 7.2 \\
\hline Japan & 0.8 & 1.3 & 0.8 & 0.7 & 1.1 & 1.2 \\
\hline Netherlands & 1.5 & 1.3 & 1.1 & 0.9 & 1.4 & 1.1 \\
\hline Russian Federation & $\ldots$ & $\ldots$ & 0.4 & 0.1 & 0.1 & 0.1 \\
\hline South Africa & 23.7 & 25.4 & 22.3 & 25.8 & 30.5 & 24.7 \\
\hline Spain & 14.7 & 12.1 & 14.2 & 6.8 & 7.2 & 6.0 \\
\hline Switzerland & $\ldots$ & 0.3 & 0.3 & 0.2 & 0.3 & 0.7 \\
\hline United Kingdom & 39.3 & 24.6 & 18.4 & 21.7 & 20.5 & 25.6 \\
\hline United States of America & 3.3 & 3.2 & 4.6 & 8.0 & 9.1 & 2.4 \\
\hline Zimbabwe & 0.3 & $\ldots$ & 0.2 & 0.1 & 0.2 & 0.1 \\
\hline Sub-total & 96.3 & 96.1 & 95.8 & 92.2 & 91.3 & 87.0 \\
\hline Other & 3.7 & 3.9 & 4.2 & 7.8 & 8.7 & 13.0 \\
\hline Total & 100.0 & 100.0 & 100.0 & 100.0 & 100.0 & 100.0 \\
\hline
\end{tabular}

Source: Central Bureau of Statistics. 
Table 25. Namibia: Developments in the Exchange Rate of the Namibia Dollar, 1998-07

(Period averages; $2000=100)$

\begin{tabular}{|c|c|c|c|c|c|c|}
\hline & \multicolumn{2}{|c|}{ Effective Exchange Rate } & \multicolumn{4}{|c|}{ Namibia dollar per foreign currency } \\
\hline & Nominal & Real & Euro & $\begin{array}{l}\text { U.S. } \\
\text { Dollar }\end{array}$ & $\begin{array}{r}\text { Botswana } \\
\text { Pula }\end{array}$ & $\begin{array}{r}\text { South African } \\
\text { Rand }\end{array}$ \\
\hline 1998 & 110.4 & 98.8 & 6.2 & 5.5 & 1.3 & 1.0 \\
\hline 1999 & 103.8 & 98.3 & 6.5 & 6.1 & 1.3 & 1.0 \\
\hline 2000 & 100.0 & 100.0 & 6.4 & 6.9 & 1.4 & 1.0 \\
\hline 2001 & 90.0 & 95.0 & 7.7 & 8.6 & 1.5 & 1.0 \\
\hline 2002 & 77.3 & 87.2 & 9.9 & 10.5 & 1.7 & 1.0 \\
\hline 2003 & 89.6 & 104.6 & 8.6 & 7.6 & 1.6 & 1.0 \\
\hline 2004 & 93.9 & 111.9 & 8.0 & 6.4 & 1.4 & 1.0 \\
\hline 2005 & 95.0 & 112.7 & 7.9 & 6.4 & 1.3 & 1.0 \\
\hline 2006 & 91.0 & 109.8 & 8.5 & 6.8 & 1.2 & 1.0 \\
\hline \multicolumn{7}{|l|}{2007} \\
\hline January & 85.8 & 104.9 & 9.3 & 7.2 & 1.2 & 1.0 \\
\hline February & 85.7 & 104.8 & 9.4 & 7.2 & 1.2 & 1.0 \\
\hline March & 84.1 & 103.4 & 9.7 & 7.3 & 1.2 & 1.0 \\
\hline April & 85.2 & 104.8 & 9.6 & 7.1 & 1.2 & 1.0 \\
\hline May & 86.0 & 106.2 & 9.5 & 7.0 & 1.1 & 1.0 \\
\hline June & 84.9 & 104.8 & 9.6 & 7.2 & 1.1 & 1.0 \\
\hline July & 85.5 & 105.9 & 9.6 & 7.0 & 1.1 & 1.0 \\
\hline August & 83.7 & 104.1 & 9.8 & 7.2 & 1.2 & 1.0 \\
\hline September & 84.0 & 104.6 & 9.9 & 7.1 & 1.1 & 1.0 \\
\hline October & 86.0 & 107.1 & 9.6 & 6.8 & 1.1 & 1.0 \\
\hline
\end{tabular}

Sources: IMF, Information Notice System; and IMF staff calculations. 